\title{
Workers of the World, Unite! Franchise Extensions and the Threat of Revolution in Europe, 1820-1938*
}

\author{
Toke S. Aidt, University of Cambridge ${ }^{\dagger}$ \\ Peter S. Jensen, University of Southern Denmark ${ }^{\ddagger}$
}

August 17, 2014

\begin{abstract}
We test the hypothesis that the extension of the voting franchise in Europe was related to the threat of revolution. We contend that international diffusion of regime contention and information about revolutionary events happening in neighboring countries generate the necessary variation in the perceived threat of revolution. Using two samples of European countries covering the period from 1820 to 1938, we find robust evidence which is consistent with the 'threat of revolution hypothesis'. We also find some evidence that war triggered suffrage reform.

Key words: Suffrage, economics of democratization, threat of revolution.

JEL classification: D7, P16.

*Acknowledgements: Comments from the Faculty Discussion Group on Political Economy at Harvard University and seminar participants at UC Davis, LSE, UCLA, Aarhus, Odense, Cambridge, Aarhus Business School, Exeter, and the 19th Silvaplana Workshop are much appreciated. We thank Patrick Kamerer and Wantje Fritschy for advising us on data collection, James Fearon, Niklas Potrafke and Roland Vaubel for sharing data with us and Todd Elder for sharing with us his STATA code. We are grateful to Daron Acemoglu, Jo Andrews, Carles Boix, Vani K. Borooah, Roger Congleton, Axel Dreher, Chris Ellis, Martin Gassebner, Miriam Golden, David Dreyer Lassen, Lars Lønstrup, Chris Meissner, Cristiano Ristuccia, James Robinson, Julia Shvets, Isleide Zissimos, Roland Vaubel, James Vreeland, Bengt-Arne Wickstrom, and Dawn Teele for insightful comments on an earlier draft of this paper. We, finally, thank Lene Holbæk for excellent editorial assistance. All remaining errors are our responsibility.

${ }^{\dagger}$ Corresponding Author: Faculty of Economics, University of Cambridge, Cambridge CB3 9DD, United Kingdom. E-mail: toke.aidt@econ.cam.ac.uk. Phone: +44 1223 335231. Fax: +44 1223

${ }^{\ddagger}$ Department of Business and Economics, University of Southern Denmark, Campusvej 55, 5230 Odense M, Denmark. E-mail: psj@sam.sdu.dk.
\end{abstract} 335475 . 


\section{Introduction}

Variations in the rules that govern who can vote have a fundamental impact on policy choices and on the longer term development prospect of a society. Historically, the power to elect or appoint leaders - Kings or Parliaments - was the privilege of small elites who derived substantial benefits from this privilege. Today in modern democracies, political power is more evenly spread and elections are governed by the principle of one (adult) person one vote. A major puzzle in political economics is why a powerful incumbent elite would want to share power with broader segments of the population. After all, by doing so, it dilutes its own political base and stands to lose significant economic rents. The 'threat of revolution hypothesis' suggests that the elite offers voting rights to avoid revolution (see, e.g., Acemoglu and Robinson, 2000, 2006). ${ }^{1}$ They do so whenever they perceive the risk to be sufficiently real. Seen in this perspective, democratization is preemptive democratization triggered by threat perceptions.

The historical record provides many suggestive examples consistent with this hypothesis $^{2}$ as does the wave of democratic reform that swept across North Africa during the Arab Spring. Beyond such examples, however, there exists surprisingly little systematic, statistical evidence. The reason is that it, unlike civil war and actual revolution, is hard to quantify the threat of a revolution. In this paper, we develop a measure of the threat of a revolution and conduct a new test of the 'threat of revolution hypothesis'. We argue that international diffusion of information related to regime contention-in particular actual large-scale revolutionary activities in other countries-may influence regime dynamics abroad through two channels. Firstly, those seeking a regime change through revolution might take inspiration from events in other countries. Secondly, the defenders of the old autocratic regime may update their assessment of how threatening the domestic situation is, and revaluate the likely consequences of a revolution or the scope for repression. Based

\footnotetext{
${ }^{1}$ For alternative economic theories of franchise extension, see Falkinger (1999), Justman and Gradstein (1999), Conley and Temini (2001), Boix (2003), Lizzeri and Persico (2004), Llavador and Oxoby (2005), Jack and Lagunoff (2006), Congleton (2007, 2011), Aidt et al. (2010), Engerman and Sokoloff (2012, chapter 4) or Aidt and Albornoz (2011).

${ }^{2}$ See, e.g., Tilly (1995) and Weyland (2010).
} 
on this, they then decide whether to relinquish power and extend voting rights preemptively. In short, we use international diffusion of information about actual revolutions to quantify the perceived threat of revolution.

This approach has two major advantages that sets it apart from previous tests. The first advantage is that we can quantify the threat of revolution for the critical period in the 19th and early 20th centuries during which the franchise was in fact extended in Europe. Previous research has been unable to do so. Przeworski (2009), for example, tests the 'threat of revolution hypothesis' on a world sample after World War I and Kim (2007) studies the link between strike activity and franchise reform in a sample of 12 Western European countries between 1880 and World War II. Our data allow us to start the analysis in 1820 . The second advantage is that we provide a direct test of the theory. Previous work by Brückner and Ciccone (2011) and Burke and Leigh (2010) establish causal links between economic shocks and democratic change which are consistent with the theory. Chaney (2013) uses deep historical data on deviant Nile floods to show that the political power of religious leaders increased during periods of economic downturn and interprets this as evidence that these leaders could coordinate a revolt. We go beyond this literature by assessing the link between the threat of revolution and democratic change directly.

We implement our test on two samples of European countries between 1820 and 1938. The focus on Europe is justified for at least two reasons. Firstly, Acemoglu and Robinson (2000) motivate their theory with detailed examples from Britain, Germany, Sweden, and France. Accordingly, although the theory of preemptive democratization is generally applicable, it is arguably particularly relevant for understanding regime dynamics in 19th and early 20th century Europe. Secondly, (modern) democratic institutions originated in Europe and spread to other parts of the world, first through colonization (Hall and Jones, 1999; Acemoglu et al., 2001) and in more recent times by providing a blueprint for the design of democratic constitutions. Seen in this perspective, gaining a better understanding of how democracy came about in Europe is an important stepping stone for understanding the spread of democracy across the world and, therefore, ultimately for understanding the influence of institutions on long-run economic development. 
Our results, based on two very different research designs, show that the threat of revolution had a major effect, not only on franchise extension as measured by the fraction of the adult population with the right to vote but also on the timing of major suffrage reforms. The baseline result is that one extra revolutionary event somewhere in Europe is associated with a two percentage point expansion of the fraction of the male population with the right to vote in neighboring countries and with a 75 percent increase in the odds of a suffrage reform.

There are two ways to read these results. The first is to give them a causal interpretation. This requires that revolutionary events in other countries are uncorrelated with unobserved country and time specific causes of democratization and that these events only affect democratization in a particular country through the effect on the perceived probability of revolution in that country. We control for many potential determinants of democratization, such as national income, urbanization, education, war, trade integration, inequality, enlightenment shocks, etc. and for unobserved country specific fixed factors and common time shocks. Yet, it is possible that countries which were 'ready' to democratize happened to be more exposed to revolutionary shocks from abroad for reasons we do not observe. Using the method proposed by Altonji et al. (2005), we find that selection on 'unobservables' must be 2.5-5.9 times stronger than selection on 'observables' for our baseline result to be entirely explained by selection bias. While perhaps not impossible, we find this highly implausible. Taken together, this gives us reason to believe that there is a causal link. The second way to read the results is as suggestive conditional correlations which are consistent with the 'threat of revolution hypothesis'. The value of uncovering these correlations is two-fold. Firstly, our data allow us to establish a strong positive correlation between the threat of revolution and democratization for the entire first wave of democratization. Previous research has focussed mostly on later waves or on part of the first wave only. Moreover, the correlation that we uncover is extremely robust to estimation method and different sets of variables capturing other theories of franchise reform. ${ }^{3}$ Secondly, we emphasize international

\footnotetext{
${ }^{3}$ The correlations uncovered by Kim (2007) for the period 1880 to 1938 are, for example, not robust to controlling for unobserved country or time fixed effects. Przeworski (2009) focuses on bivariate correlations between his measure of the threat (based on data on riots and strikes) and his measure of democratization in order to maximize the number of cases.
} 
diffusion of information on regime contention as one possible mechanism through which the threat of revolution might have induced preemptive democratization. ${ }^{4}$ This provides a new perspective on the theory.

The rest of the paper is organized as follows. In section 2, we present a twocountry model of (preemptive) franchise reform which motivates our empirical investigation. In section 3 , we present data on revolutionary threats and suffrage reform. In section 4 , we present our two research designs. In sections 5 and 6 , we report the results and discuss confounding factors. In section 7, we discuss other theories of franchise reform. In section 8 , we conclude. The supplementary material contains a Theory Appendix with some proofs, three data appendices (Data Appendix A to C) detailing our data material and the sources consulted and providing a table with descriptive statistics. Appendix D contains additional econometric checks.

\section{Theory}

Our test of the 'threat of revolution hypothesis' is based on the idea that revolutionary events abroad represent shocks to the information set of the old regime elites and to potential revolutionaries and may, through those two channels, be triggers of suffrage reform. To illustrate this logic, we develop a two-country version of Acemoglu and Robinson's (2000) model of preemptive franchise extension. ${ }^{5}$

\subsection{Assumptions}

We consider two countries, indexed by $i \in\{1,2\}$, with an infinite time horizon, $t=0,1, \ldots \infty$. We omit, for simplicity, the country index on variables and parameters that, by assumption, are the same. The political state in country $i\left(S_{i t}^{P o l}\right)$ at time $t$ can be either democracy $(\mathcal{D})$, autocracy $(\mathcal{A})$, or a post-revolutionary regime $(\mathcal{S})$, i.e., $S_{i t}^{P o l} \in\{\mathcal{D}, \mathcal{A}, \mathcal{S}\}$. Each country is populated by two groups, called the insiders and the outsiders, and indexed by $g \in\{I, O\} .{ }^{6}$ Utility is discounted by the factor

\footnotetext{
${ }^{4}$ The literature on civil war also emphasizes international diffusion (Sambanis and Hegre, 2006). We focus on the diffusion of the threat of revolution rather than full-blown civil war. Revolution and conflict have many causes including economic shocks (Berger and Spoerer, 2001) and ethnical conflict (Esteban et al. 2012).

${ }^{5}$ See Dorsch and Maarek (2014) for a related model.

${ }^{6}$ We use the terms 'insiders' and 'outsiders' to allow for alternative interpretations. Typically, the insiders represent the old regime elites (e.g., the landed aristocracy) while the outsiders may
} 
$\beta$. We specify the per-period utility per member of group $g$ as functions of the prevailing political state and denote them by $y_{g}\left(S_{i t}^{P o l}\right) .{ }^{7}$ Under autocracy, the insiders, despite being a minority, control the government and bias policy in their favour. The utility of each insider is $y_{I}(\mathcal{A})$, while that of each outsider is $y_{O}(\mathcal{A})<$ $y_{I}(\mathcal{A})$. Under democracy, the outsiders hold the majority and introduce policies that benefit them and harm the insiders. As a consequence, $y_{I}(\mathcal{A})>y_{I}(\mathcal{D})>0$ and $y_{O}(\mathcal{A})<y_{O}(\mathcal{D})$. Finally, in the post-revolutionary regime, the insiders fare worse than under democracy, while the outsiders are better off, i.e., $y_{I}(\mathcal{S})=0$ and $y_{O}(\mathcal{S}) \geq y_{O}(\mathcal{D}){ }^{8}$ We treat the insiders and outsiders of each country as (four) players of a dynamic game and refer to them collectively as the decision makers.

The initial political state is autocracy in both countries. A regime transition happens either through a revolution or through democratization. We use the term 'revolution' broadly to mean any form of costly social transformation forced upon the insiders by the outsiders, ${ }^{9}$ whereas democratization is understood as orderly political transformation designed and controlled by the insiders. We denote the outsiders' decision to attempt a revolution by $\rho_{i t} \in\{Y, N\}$, where $\rho_{i t}=Y$ means that an attempt was made and $\rho_{i t}=N$ that no attempt was made. A revolution attempt costs each outsider $\mu$ units of utility and its success depends on the social state $\left(S_{t}^{S o c} \in\{G, B\}\right)$. In social state $B$, a revolution always fails. In social state $G$, it succeeds with probability $p$. The post-revolutionary regime is an absorbing

represent the working class, moderate liberals recruited from the upper middle class and the liberal aristocracy, an emerging lower middle class, parts of new industrial elites, or intellectuals and discontented gentry. The post-revolutionary regime and democracy can, accordingly, be interpreted as socialism versus parliamentary government elected on universal suffrage, as a republic (with rules that are particularly biased against the old regime elites) versus a constitutional monarchy with aristocratic control of an upper chamber but popular elections to a lower chamber, etc.

${ }^{7}$ These can be derived from specific assumptions about endowments, production technologies, and tax instruments, as in Acemoglu and Robinson (2000, 2006). By not explicitly modeling policy choices, we rule out that the insiders may offer fiscal transfers to avoid a revolution. The choice between fiscal transfers and a franchise extension is vital for understanding why democratization has commitment value, but is not important for understanding our empirical strategy. We return to the question of transfers in Section 4.

${ }^{8}$ Tullock (1971) and Kuran (1989) stress that it is the private returns that matter for an individual's incentive to participate in a revolution. We assume that non-participating outsiders are excluded from the benefits associated with the post-revolutionary regime (see Acemoglu and Robinson, 2000, p. 1172).

${ }^{9}$ Accordingly, revolution attempts can take many different forms, ranging from a challenge from an emerging liberal-minded or radical middle class to a full-blown communist challenge as in Russia in 1917. 
state. The discounted utility of an outsider after a successful revolution is $\frac{y_{O}(\mathcal{S})}{1-\beta}-\mu$.

The key assumption of the model is that the social states in the two countries are (positively) correlated. Correlation can be induced by international business cycle shocks, by weather shocks or by disease-induced crop failures (e.g., the potato blight). Alternatively, the source of correlation may be purely informational. A successful revolution requires coordination amongst the revolutionaries. Seeing a successful revolution abroad may foster coordination either through a demonstration effect or by serving as a rally call. The correlation need not be equally strong between all pairs of countries and, in practice, its strength is a function of economic, social and geographical proximity. For the purpose of the theoretical analysis, however, we make the extreme assumption that the social state is the same in the two countries and is transitory, but all we need is some degree of correlation.

To avoid a revolution, the insiders can extend the franchise $\left(d_{i t} \in\{Y, N\}\right)$ or they can repress $\left(r_{i t} \in\{Y, N\}\right)$. A preemptive franchise extension transfers power permanently to the outsiders and is sufficient to prevent a revolution. ${ }^{10}$ Repression makes any attempt at revolution unsuccessful but costs each insider $\sigma>0$ units of utility. Neither the insiders nor the outsiders observe the social state directly. ${ }^{11}$ They must, therefore, estimate based on 'reports' $\left(L_{i t}\right)$ what the social state is before acting. The decision makers of a given country observe the same reports and in the absence of an informative report, everyone agree that the social state is $G$ with probability $q<1 .{ }^{12}$ The substantive assumption is that the reports differ across countries. In country 1 , the decision makers receive local reports, i.e., reports that are not directly observed by decision makers in country 2 . These reports are either uninformative $\left(L_{1 t}=1\right)$ or informative $\left(L_{1 t}=l\right)$ where $l \in(q, 1)$. Upon receiving a report, the decision makers update their belief that the social state is $G$ to $q_{1 t}=\operatorname{Pr}\left(G \mid L_{1 t}\right)=\frac{q}{L_{1 t}}$. Since $l \in(q, 1)$, the belief that the social state is $G$ is revised upwards after receiving an informative report and not revised after an uninformative report, i.e., $\operatorname{Pr}(G \mid l)=\frac{q}{l}>\operatorname{Pr}(G \mid 1)=q \cdot{ }^{13}$ In country 2, the

\footnotetext{
${ }^{10}$ A sufficient condition is that $\mu>\frac{y_{O}(\mathcal{S})-y_{O}(\mathcal{D})}{1-\beta}$.

${ }^{11}$ See Andrews and Jackson (2005).

${ }^{12}$ Since at time $t$ no reports for future periods have yet been received, all decision makers believe at time $t$ that the social state is $G$ with probability $q$ from period $t+1$ onwards.

${ }^{13}$ The restriction on $l$ implies that the beliefs are never downgraded after receiving an informative
} 
decision makers observe what happened in country 1 as information diffuses from one country to another. In particular, they observe the political state of country 1 and the decisions made by the insiders $\left(d_{1 t}\right.$ and $\left.r_{1 t}\right)$ and by the outsiders $\left(\rho_{1 t}\right)$, i.e., $L_{2 t} \in\left\{S_{1 t}^{P o l}, d_{1 t}, r_{1 t}, \rho_{1 t}\right\}$, and base their decisions on these international reports.

At the beginning of each period, the social state $S_{t}^{S o c} \in\{G, B\}$ is determined by Nature. The decision makers in country 1 act before those in country 2 and they only need to act if the political state is autocracy $\left(S_{1 t}^{P o l}=\mathcal{A}\right) \cdot{ }^{14}$ In that case, the sequence of events is:

1. The decision makers in country 1 receive the local report $L_{1 t} \in\{1, l\}$ and update their belief about the threat of revolution to $q_{1 t}=\operatorname{Pr}\left(G \mid L_{1 t}\right)$.

2. The insiders decide whether to extend the franchise $\left(d_{1 t}\right)$ or to repress $\left(r_{1 t}\right)$.

(a) If they extend, country 1 becomes a democracy $\left(S_{1 t}^{\text {Pol }}=\mathcal{D}\right)$ and utilities for the period are $y_{g}(\mathcal{D})$ for $g \in\{I, O\}$, and the period ends.

(b) If they repress, any attempt at revolution fails (so the outsiders never revolt). The political state continues to be autocracy $\left(S_{1 t}^{P o l}=\mathcal{A}\right)$ and utilities, gross of the utility cost of repression $\sigma$, for the period are $y_{g}(\mathcal{A})$ for $g \in\{I, O\}$, and the period ends.

(c) If they decide to neither extend nor to repress, then stage 3 applies.

3. The outsiders decide whether or not to initiate a revolution. If they do and the social state is $G$, country 1 experiences with probability $p$ a transition to the post-revolutionary regime $\left(S_{1 t}^{P o l}=\mathcal{S}\right)$ while with probability $1-p$, the revolution fails and the country continues in autocracy $\left(S_{1 t}^{P o l}=\mathcal{A}\right)$. If the social state is $B$, a revolution always fails. Utilities for the period are, gross of the utility cost of revolution $\mu, y_{g}\left(S_{1 t}^{\text {Pol }}\right)$ for $g \in\{I, O\}$ and $S_{1 t}^{\text {Pol }} \in\{\mathcal{S}, \mathcal{A}\}$, and the period ends. If the outsiders do not attempt a revolution, the country continues in autocracy and utilities are $y_{g}(\mathcal{A})$ for $g \in\{I, O\}$, and the period ends.

report. We could allow for this by adding a third type of report, but this complicates the analysis without adding extra insights. The restriction also ensures that $\operatorname{Pr}(G \mid l)$ is bounded below 1 .

${ }^{14}$ If $S_{1 t}^{P o l} \in\{\mathcal{D}, \mathcal{S}\}$ at time $t$, no further decisions are required. 
The sequence of events in country 2 is similar, except for stage 1:

1'. The decision makers in country 2 receive the international report $L_{2 t} \in$ $\left\{S_{1 t}^{\text {Pol }}, d_{1 t}, r_{1 t}, \rho_{1 t}\right\}$ and update their beliefs about the threat of revolution to $q_{2 t}=\operatorname{Pr}\left(G \mid L_{2 t}\right)$.

We emphasize two features of the information structure. Firstly, nobody observes the social state directly. For this reason, the model exhibits equilibrium paths, along which revolutions actually happen. ${ }^{15}$ Secondly, international diffusion of information cannot by itself explain preemptive suffrage extensions. An initial trigger is needed. This is the role played by the local reports in country 1 .

\subsection{Analysis}

We first study pure strategy Markov perfect equilibria in country 1. Subsequently, we study how international diffusion of information about events in that country affects regime dynamics in country 2 .

\subsubsection{Regime Dynamics in Country 1}

The so-called revolution constraint, which controls whether the outsiders in stage 3 revolt or not, plays an important role for regime dynamics and we begin the analysis with a discussion of it. Since the outsides do not know the true social state, they revolt if their updated belief $\left(q_{1 t}\right)$ that the state is $G$ is greater than the threshold ${ }^{16}$

$$
\widehat{q}_{R E V O L T} \equiv \frac{1}{p} \frac{(1-\beta) \mu}{y_{O}(\mathcal{S})-y_{O}(\mathcal{A})}
$$

and do not revolt if $q_{1 t}<\widehat{q}_{R E V O L T}$. We make the following assumption.

Assumption $1 q<\widehat{q}_{R E V O L T}<\frac{q(1-p)}{l-p q}$.

This assumption guarantees that the outsiders never revolt after observing an uninformative report $\left(L_{1 t}=1 \Rightarrow q_{1 t}=q\right)$ but they will revolt upon observing an

\footnotetext{
${ }^{15}$ In Acemoglu and Robinson (2000), where all parties are fully informed about the social state, revolutions cannot happen in equilibrium because the insiders always want to preempt it. Ellis and Fender (2011) study a richer environment in which information cascades can generate revolutions.

${ }^{16}$ Derivation of this and subsequent conditions are in the Theory Appendix included with the supplementary material.
} 
informative report $\left(L_{1 t}=l \Rightarrow q_{1 t}=\frac{q}{l}>\frac{q(1-p)}{l-p q}\right)$ unless the insiders take preemptive action. ${ }^{17}$ In the latter case, the revolution constraint binds.

In stage 2, the insiders foresee whether the revolution constraint binds or not. When it binds, they face a choice between three options: democratize, repress, or run the risk of a revolution. We rank these options as follows. First, franchise extension is better than repression if

$$
[D]: \sigma>\frac{y_{I}(\mathcal{A})-y_{I}(\mathcal{D})}{1-\beta} .
$$

Condition $[D]$ shows that the insiders of a country with an ineffective repression technology (a high $\sigma$ ) or in which democracy does not pose a serious threat to them $\left(y_{I}(\mathcal{A})-y_{I}(\mathcal{D})\right.$ is small)-perhaps because income inequality is modest-are likely to prefer to extend the franchise preemptively rather than to repress. Second, if the updated belief following an informative report $\left(q_{1 t}=\frac{q}{l}\right)$ is sufficiently large, then either repression or democratization dominates running the risk of a revolution. More specifically, if condition $[D]$ holds, then a preemptive franchise extension is optimal if

$$
\frac{q}{l} \geq \frac{1}{p} \frac{y_{I}(\mathcal{A})-y_{I}(\mathcal{D})}{y_{I}(\mathcal{A})} \equiv \widehat{q}_{D E M O C R A C Y}
$$

and if $[D]$ fails, then repression is optimal if

$$
\frac{q}{l} \geq \frac{1}{p} \frac{\sigma(1-\beta)}{y_{I}(\mathcal{A})} \equiv \widehat{q}_{R E P R E S S I O N} .
$$

We make the following additional assumptions.

Assumption $2 \widehat{q}_{R E V O L T}<\min \left\{\widehat{q}_{D E M O C R A C Y}, \widehat{q}_{R E P R E S S I O N}\right\}$.

Assumption $3 \sigma<\frac{p y_{I}(\mathcal{A})}{1-\beta}$.

Assumption 2 ensures that the outsiders are willing to revolt in situations where the insiders are unwilling to preempt a revolt. Assumption 3 imposes a lower bound on how willing they are to run this risk. It plays a role for the regime dynamics in country 2. Proposition 1 characterizes the Markov Perfect equilibrium in country 1.

\footnotetext{
${ }^{17}$ It is sufficient for the analysis of country 1 to assume that $\widehat{q}_{R E V O L T}<\frac{q}{l}$. We assume that $\widehat{q}_{R E V O L T}<\frac{q(1-p)}{l-p q}$ because this restriction matters for the analysis of country 2 .
} 
Proposition 1 (Political transitions in country 1) Assume that Assumption 1 and 2 hold and that country 1 is an autocracy at the begining of period $t$.

1. Suppose that $L_{1 t}=1$. The outsiders never revolt and the insiders never repress or extend the franchise preemptively. The political regime continues to be $\mathcal{A}$.

2. Suppose that $L_{1 t}=l$.

(a) If condition $[D]$ holds and $\frac{q}{l} \geq \widehat{q}_{D E M O C R A C Y}$, then a preemptive franchise extension takes place. The political regime becomes $\mathcal{D}$ and no revolt is attempted.

(b) If condition $[D]$ fails and $\frac{q}{l} \geq \widehat{q}_{R E P R E S S I O N}$, then the insiders repress. The political regime continues to be $\mathcal{A}$ and no revolt is attempted.

(c) If $\frac{q}{l}<\min \left\{\widehat{q}_{R E P R E S S I O N}, \widehat{q}_{D E M O C R A C Y}\right\}$, the insiders take no preemptive action and a revolt takes place. If it fails, the political regime continues to be $\mathcal{A}$. If it succeeds, the political regime becomes $\mathcal{S}$.

\subsubsection{Regime Dynamics in Country 2}

The decision makers in country 2 observe the political state and the choices made by the insiders (repression or suffrage reform) and the outsiders (revolt in country 1, i.e., $\left(L_{2 t}=\left\{S_{1 t}^{P o l}, \rho_{1 t}, r_{1 t}, d_{1 t}\right\}\right)$. Given this information, they update their beliefs, $q_{2 t}=\operatorname{Pr}\left(G \mid L_{2 t}\right)$, about the social state rationally using Proposition 1 and, in turn, base their decisions to reform, repress, or revolt on this. The thresholds $\widehat{q}_{R E V O L T}$, $\widehat{q}_{R E P R E S S I O N}$, and $\widehat{q}_{D E M O C R A C Y}$ and condition $[\mathrm{D}]$ are the same as in country 1. We summarize this diffusion process as follows:

1. Suppose the political state of country 1 is $\mathcal{A}$, that the insiders of country 1 did not repress $\left(r_{1 t}=N\right)$, and that the outsiders did not revolt $\left(\rho_{1 t}=N\right)$. Then the decision makers in country 2 conclude that $L_{1 t}=1$ and believe that $q_{2 t}=q$. Given that, the revolution constraint does not bind in country 2 (and the outsiders will not revolt) and the political state remains $\mathcal{A}$.

2. If the decision makers in country 2 observe either a preemptive franchise extension $\left(d_{1 t}=Y\right)$ or repression $\left(r_{1 t}=Y\right)$, then they conclude that $L_{1 t}=l$. 
This is not sufficient to establish if the social state is, in fact, $G$ but makes it more likely that it is. The updated probability that the social state is $G$ is $\frac{q}{l}>q$. Given Assumption 1, the revolution constraint binds. The insiders respond by imitating the choice made by the insiders in country 1 .

3. If the decision makers in country 2 observe a successful revolution $\left(\rho_{1 t}=Y\right.$ and $\left.S_{1 t}^{P o l}=\mathcal{S}\right)$ in country 1 , they can unambiguously conclude that the social state is $G$. The revolution constraint binds. Given Assumption 3, the insiders want to preempt a local revolt, either through a preemptive franchise extension if condition $[D]$ holds or by repression otherwise.

4. If the decision makers in country 2 observe an unsuccessful revolt $\left(\rho_{1 t}=Y\right.$ and $\left.S_{1 t}^{P o l}=\mathcal{A}\right)$, they conclude that $L_{1 t}=l$ but cannot deduce if the social state is, in fact, $G$. The updated probability that the social state is $G$ is

$$
q_{2 t}=\operatorname{Pr}(G \mid\{\mathcal{A}, Y, N, N\})=\frac{\frac{q}{l}(1-p)}{1-\frac{q}{l}+(1-p) \frac{q}{l}}=\frac{q(1-p)}{l-p q}<\frac{q}{l} .
$$

By Assumption 1, $\frac{q(1-p)}{l-p q}>\widehat{q}_{R E V O L T}$ and the revolution constraint binds. Since the insiders in country 1 did not do anything to prevent the revolt, Assumption 2 implies that

$$
\widehat{q}_{R E V O L T}<\frac{q}{l}<\min \left\{\widehat{q}_{D E M O C R A C Y}, \widehat{q}_{R E P R E S S I O N}\right\}
$$

Since $\frac{q(1-p)}{l-p q}<\frac{q}{l}$, the insiders in country 2 do not want to preempt a revolt either. A failed revolution attempt in country 1 triggers a revolution attempt in country 2. This generates a revolution snowball effect.

We present the key insights from this analysis in two propositions.

Proposition 2 (Preemptive franchise extension). Let Assumptions 1 to 3 hold. Suppose that

$$
\frac{q}{l}<\min \left\{\widehat{q}_{D E M O C R A C Y}, \widehat{q}_{R E P R E S S I O N}\right\}
$$

A successful revolution in country 1 triggers a preemptive suffrage reform in country 2 if condition $[D]$ holds and repression if not. 
The 'revolution shock' originating from country 1 diffuses to country 2 through two channels. On the one hand, it serves as a rally call for the outsiders who upon observing the successful revolution abroad believe that they will (most likely) be successful as well. This makes the threat of revolution credible in country 2. On the other hand, it provides conclusive evidence to the insiders that they must act preemptively to avoid a revolution. ${ }^{18}$ They do so either through preemptive suffrage reform or, if they have access to an effective repression technology ( $\sigma$ is low) or feel particularly threatened by democracy $\left(y_{I}(\mathcal{A})-y_{I}(\mathcal{D})\right.$ is large), by repression. This captures the logic behind our test of the 'threat of revolution hypothesis': we propose to study empirically if revolutionary events in other countries affect the likelihood of suffrage reform at home positively.

In addition to this main test, the theory suggests auxiliary tests. First, a given 'revolution shock' abroad has a smaller impact on suffrage reform (1) in countries where the insiders are particularly threatened by democracy and (2) in countries that are 'distant' from the source of the revolutionary event. The first auxiliary test follows directly from condition [D]. The second auxiliary test follows from the observation that a 'revolution shock' in country 1 has no effect on suffrage reform in country 2 if the social states were independent. Insofar as the strength of the correlation between the social states is related to economic, social and geographical distance between pairs of countries, the theory delivers this second auxiliary prediction. The next proposition states one further prediction:

Proposition 3 (Democracy begets democracy). Let Assumptions 1 to 3 hold. Suppose condition $[D]$ holds and that

$$
\frac{q}{l}>\widehat{q}_{D E M O C R A C Y}
$$

A franchise extension in country 1 triggers a franchise extension in country 2.

This proposition highlights an indirect channel through which information about revolutionary threats can diffuse internationally and be a cause of preemptive democratization. It happens when the insiders in country 2 observe a preemptive

\footnotetext{
${ }^{18}$ They learn that the social state is $G$ and given Assumption 3, they act preemptively.
} 
suffrage reform in country 1 . From this, they deduce that the revolution constraint must be binding and that they must take action if they want to prevent a revolt at home. Since the insiders in country 1 democratized preemptively, it is optimal for the insiders in country 2 to imitate. The reason is not that democracy has any intrinsic value or that a certain spur of enlightenment has affected the insiders' attitude to reform. The reason is that the (preemptive) reform in country 1 warns them that they too must act to avoid a revolution. This provides an additional empirical implication which we can test empirically.

\section{Franchise Reforms and the Threat of Revolu- tion: Measurements}

To test the 'threat of revolution hypothesis', we need quantitative measures of democratization and the threat of revolution. We equate democratization with the extension of the franchise for two reasons. Firstly, the hypothesis is first and foremost a hypothesis of franchise extension. Secondly, the hypothesis does not imply that the old regime elites needed to introduce the full package of democratic institutions (voting rights to all adults, secret ballot, civil liberties, effective accountability, etc.). On the contrary, it suggests that the elites would seek to grant the minimum concession needed to 'calm the waters' and avoid a revolution. Accordingly, the preemptive reforms induced by the threat of revolution often involved sharing as little de facto power as possible, or as Tilly (1995, p. 24) puts it, in his discussion of the Great Reform Act of 1832 in Britain, the "expanded suffrage afforded resulted from the government's frightened, but astutely minimal concessions to popular mobilization". ${ }^{19}$ Granting the right to vote is by far the most visible and immediate de jure democratic concession that an elite can make and, therefore, in practice the most likely candidate for preemptive democratization. ${ }^{20}$ This, we believe, makes

\footnotetext{
${ }^{19}$ De facto power conferred to newly enfranchised groups can be limited in many ways. For example, it was common to maintain bicameral systems. While the franchise for the lower chamber was widened, the old regime elites preserved control of the upper chamber and through that the right to veto policy. Another mechanism was outright electoral corruption, often maintained by keeping the ballot open. The material point is whether the concessions at the time they were offered were accepted by the potential revolutionaries and thus eliminated the threat of revolution, and not whether they with the benefit of hindsight reallocated a lot of de facto political power.

${ }^{20}$ As emphasized by Kuran (1989), revolutions require leadership as well as popular support to succeed. Consequently, democratization can, in principle, preempt revolution by granting conces-
} 
composite measures of democratization, such as those proposed by Przeworski et al. (2000) or Boix (2003) and used extensively in research on the causes of democratic change during the third wave of democratization (see, e.g., Gassebner et al. (2013)), inappropriate for our test.

Given this choice, we measure enfranchisement of hitherto disenfranchised socialeconomic groups of adult men, as opposed to enfranchisement of, say, women or the young. We do this in two ways. Firstly, we record the size of the electorate (with the right to vote in national elections to the lower legislative chamber) in percentage of its reference age and sex group over time and space. Before women's suffrage, the reference group is all men of voting age, and after, it is all citizens of voting age. This measure, which we call suffrage, quantifies on a scale from 0 to 100 the impact of income, property holding, and wealth restrictions on the right to vote in isolation from the effect of women's suffrage. We assign the value of zero to suffrage for the years before national elections to the (lower) legislative body were based on a well-defined set of suffrage rules. This measure can, based on information from Flora et al. (1983), be constructed for the 12 Western European countries listed in panel A of Table 1. Secondly, we record in column two of Table 1 the year of all reforms that enfranchise new socioeconomic groups by lowering income and property requirements, etc. ${ }^{21}$ Information on this can be obtained for the ten additional countries listed in panel B of the table. ${ }^{22}$ We refer to the sample of 21 countries as the 'broader European sample' and the sample of the 12 Western European countries as the 'Western European sample'. The transition to constitutional democracy was progressive and gradual in most countries. Yet, Italy, Austria, Spain, Portugal, and Germany during the interwar period and France during the Second Empire from 1852 to 1869 constitute examples of backlashes to democracy. The years of

sions to the potential revolutionary leadership without offering much to the popular supporters of revolution. In particular, in the 19th century, where the potential leadership was typically found amongst the radicals and liberal-minded middle classes, small franchise extensions that benefited these groups could be effective in stopping a revolution in the making. A good example of this is the Great Reform Act of 1832 in Britain (see, e.g. Aidt and Franck, 2014).

${ }^{21}$ Data Appendix $A$ contains a detailed discussion of the coding of each reform.

${ }^{22} \mathrm{~A}$ country enters the sample when it becomes an independent state and drops out if it regresses back into some form of autocracy or into civil war. Data Appendix A provides further details on the construction of the sample. We report the year of entry and, if applicable, year of exit for each country in column 1 of Table 1. 
these and other examples of (de facto) franchise contractions are listed in column four. We explore this information to account for the durability of past franchise extensions.

Our test of the 'threat of revolution hypothesis' is, as discussed above, based on the idea that regime contention and information on revolutionary events diffuse internationally. To quantify this diffusion process, we have recorded 42 'revolutionary events' in Europe during the period. ${ }^{23}$ 'Revolutionary events' are defined as 'those instances when for a month or more at least two blocs of people backed by armed force and receiving support from a substantial part of the general population exercised control over important segments of the state organization', Tilly (2004, p. 73). We have excluded instances of coup d'état and civil war since they are conceptually different. The years of the 'revolutionary events' are listed in column three of Table $1 .{ }^{24}$ These include the three major waves of revolution in Europe that occurred in 1820, 1830 and 1848 as well as the Russian revolutions and many other events.

Based on this information, we construct three different indicators of the threat of revolution as perceived in country $i$ in year $t\left(T R_{i t}^{k}\right)$. To understand how this is done, let $R_{j t}$ be the number of revolutionary events that took place in country $j$ in year $t$ and let $W_{i j}^{k}$ be the spatial weight attached to the revolutionary event in country $i$ for country $j$ where $k \in\{u, g, l\}$ is the index for a particular weight. The indicators of the threat of revolution are then defined as:

$$
T R_{i t}^{k}=\sum_{j \neq i} W_{i j}^{k} R_{j t}
$$

The first indicator, $k=u$, is an unweighted sum of the number of revolutionary events in each year, i.e., $W_{i j}^{u}=1$ for all $i$ and $j$ with $i \neq j$. The 'threat of revolution hypothesis' suggests, however, that the information content of events is likely to be larger for events that happen in countries that are geographically, economically, or culturally closer. Our two other indicators recognize this aspect of the diffusion process. The second indicator, $k=g$, uses geographical distance

\footnotetext{
${ }^{23}$ These are coded based on the works by Tilly $(1993,2004)$ and Todd (1998) and supplemented with information from Encyclopaedia Britannica.

${ }^{24}$ All the events are detailed in Data Appendix $B$.
} 
to define the weight and let $W_{i j}^{g}=\frac{1}{D_{i j}}$, where $D_{i j}$ is the distance in kilometers between the capitals of the country pair. The third indicator, $k=l$, uses linguistic distance to define the weights and let $W_{i j}^{l}=1-\frac{\sqrt{15-\# c o m m o n}}{i j}$, where \#common $i j$ is the number of common branches (up to 15) in the linguistic tree for each pair of countries (Fearon, 2003). Arguably, sharing a common language and geographical proximity are both plausible diffusion channels. For the main analysis, we construct each of the three indicators using the 16 major events, indicated in boldface in Table 1. In robustness checks, we make use of all 42 events. We exclude revolutionary events within a country in all these calculations. The rationale for doing so is that they represent the impulse to the diffusion process but are not a consequence of it.

For these data to be useful for our proposed test, it must be true (1) that information about these events spread around Europe fast, and (2) that the information was, in fact, used by the governing classes and potential regime challengers in other countries to assess the likelihood of a successful home-grown revolution. We discuss each of these requirements before we proceed. Firstly, even in the early part of the 19th century, news spread fast within Europe. Stuurman (1991), for example, discusses how news of the French Revolution in 1848 reached Dutch merchants off the coast of Africa within weeks and presumably long after the news was known in the Netherlands. Likewise, English newspapers reported the July revolution in Paris in 1830 on August 3 (Brock, 1973, p. 102). Later on in the century, with the construction of telegraph lines, news from all corners of Europe could spread quickly, not just amongst the European elites but also, as printed media and literacy spread, amongst the general population.

Secondly, the historical record contains plenty of examples demonstrating that the governing classes used information about revolutionary events abroad to assess the threat of revolution at home and that opposition groups took inspiration from events happening in neighboring countries. One example is the impact that the July 1830 revolution in France had on the attitude of British Members of Parliament towards franchise reform. Some commentators at the time, in fact, suggested that news of the July revolution triggered franchise reform in Britain by making the governing classes aware of the threat of revolution (Halevy, 1935) and when Lord 
Grey introduced the reform bill to the House of Commons with the words, 'the principal of my reform is to prevent the necessity of revolution[...] I am reforming to preserve, not to overthrow', he made a clear reference to the perceived risk of violent social change. Another example is the impact that the European revolutions of 1848 had in Denmark and in the Netherlands. As Weyland (2010, p. 1162) puts it, 'the Danish king in March 1848 had the opportunity to observe the daily advance of revolution across Central Europe: he could almost predict the hour when it would reach Copenhagen [....] On March 18, Frederic VII made hasty concession [including a franchise reform] to the restless masses gathered outside his palace to avert an explosion in Denmark'. Along similar lines, Stuurman (1991, p. 464) summarizes the situation in the Netherlands in 1848 as follows: 'although the Netherlands did not experience anything like a violent revolution in 1848, the political events of that year assuredly deviated from the normal course of Dutch politics [...] the fundamental cause of the non-violent revolution in the Netherlands is without doubt to be found in the European revolutions, notably those in France, Germany and Austria.' Yet another example is the Russian Revolution in 1917 where 'heightened workingclass pressure [in Germany, Belgium, Sweden and Finland] was surely activated as much by the Russian Revolution as by World War I. From the side of the working class, what perhaps changed most was not the greater force of its pro-democratic agitation, but the revolutionary rather than the democratic example of the Russian Revolution' (Collier, 1999, p. 78). Likewise, Weyland (2010) contends that fear of bolshevism induced preemptive suffrage reforms in Britain, Sweden, Germany, and Finland in 1917-19. In all these examples, news about revolutions abroad informed reform decisions reached by the elites across the continent, and it did so because it served as a rally call and as inspiration for local revolutionaries.

$<$ Table 1 to appear here $>$

\section{Estimation Strategy}

We use two different research designs to implement our test of the "threat of revolution hypothesis'. In the first design, the dependent variable is the continuous 
variable suffrage and the baseline specification is a fixed effects panel model:

$$
\text { suffrage }_{i t}=\theta \text { suffrage }_{i t-1}+\beta_{1} T R_{i t}^{k}+X_{i t} v+\varphi_{i}+\lambda_{t}+\varepsilon_{i t},
$$

where $\varphi_{i}$ is a country fixed effect, $\lambda_{t}$ is two-year time fixed effects and $\varepsilon_{i t}$ is an error term with $E\left(\varepsilon_{i t}\right)=0$. The vector $X_{i t}$ includes other potential determinates of the suffrage. To control for the 'initial' political state, we include a lagged dependent variable. The error terms $\varepsilon_{i t}$ are unlikely to satisfy the standard assumptions of temporal and spatial independence and homoskedasticity. In the baseline specification, we, therefore, take account of i) cross-country spatial correlation amongst the disturbances, ii) autocorrelation, and iii) panel heteroskedasticity. We adopt the panel correction recommended by Beck and Katz (1995) to model unrestricted spatial correlation and we cluster the error terms at the country level. ${ }^{25}$ These standard errors cannot be estimated with one-year time fixed effects because of the high correlation between year effects and the threat of revolution variables. This is the reason why we include two-year time fixed effects in the baseline. In section 5.2.4, we show that the results are robust to controlling for one-year time fixed effects in specifications where we do not model unrestricted spatial correlation. Theory predicts that $\beta_{1}$ is positive.

Our second research design is an event history model. Here, the objective is to investigate whether the threat of revolution explains the timing of suffrage reforms. We code, using the information from column two in Table 1, the dependent variable reform $_{i t}$ as one if country $i$ introduced a franchise extension in year $t$ and as zero in the years before and after that. A country drops out of the sample in the year after it introduced universal male suffrage or if it, before that happened, became a dictatorship. We do not know precisely when a country became at 'risk' of extending the franchise. We deal with this problem of left censoring by assuming that countries enter the 'risk set' either in 1820 or at the time of independence (as recorded in column one of Table 1). As in Beck et al. (1998), we estimate the following discrete

\footnotetext{
${ }^{25}$ The measures of the threat of revolution are serially correlated by construction. This can, as pointed out by Bertrand et al. (2004), generate spurious correlation. We use a parametric method to correct for this. For each country, we use the estimated autocorrelation coefficients from an $\mathrm{AR}(1)$ process to adjust the standard errors. With more than 100 years of data, it is unlikely that these coefficients are biased downwards. The estimated autocorrelation coefficients are small (around 0.05). We use the PCSE procedure in STATA 12 to make these adjustments.
} 
logistic model

$$
P\left(\text { reform }_{i t}=1 \mid T R_{i t}^{k}, X_{i t}, M_{t-1}=0\right)=\frac{1}{1+e^{-\left(\bar{\beta}_{1} T R_{i t}^{k}+X_{i t} \bar{\nu}+H(.)\right)}},
$$

where $X_{i t}$ is the vector of other potential determinates of the suffrage. The indicator variable $M_{t-1}$ is equal to zero in each year before universal male suffrage and equal to one thereafter. The function $H($.$) captures duration dependence in the hazard$ rate $^{26}$ We cluster the standard errors at the country level. Theory predicts that $\bar{\beta}_{1}$ is positive.

The two research designs capture different aspects of the democratization process. The panel model captures the evolution of the fraction of the population with voting rights, over time and space. The event history model captures the timing of suffrage reform. In both cases, identification requires the assumption of conditional independence. We discuss how reasonable this assumption is and potential threats to it below, but first we introduce the co-variates $\left(X_{i t}\right)$. They are motivated by theoretical considerations but necessarily constrained by data availability. In the baseline, we only include variables for which we have data for the whole sample period. ${ }^{27}$ In extensions, we add variables (to be introduced later) with partial time coverage to address particular issues. Firstly, some co-variates are motivated by the modernization hypothesis, initially formulated Lipset (1960). He stressed the gradual increase in income and the improvement in education attainment as causes of democratization. We capture modernization by GDP per capita and a dummy variable, educational attainment, that is equal to one if enrollment in primary education is greater than 60 per cent and zero otherwise. The variable, urbanization rate, also captures aspects of modernization. As stressed by Przeworski (2009), it can, in addition, serve as a proxy for the demand for public goods and be used to control for a positive association between the value of public goods and suffrage reform, as predicted by Lizzeri and Persico (2004). ${ }^{28}$ Secondly, Lopez-Cordova and

\footnotetext{
${ }^{26}$ The argument of the function $H($.$) is t-t_{i}^{p}$, where $t_{i}^{p}$ represents either the year in which country $i$ enters the 'risk set' or the year of the previous franchise extension within the sample period. We estimate $H($.$) using natural cubic splines and use the estimated spline coefficients$ along with the cumulation of years since the last reform (or since entry to the sample) to model duration dependence. Based on a sequence of F-tests, we use a specification with two knots.

${ }^{27}$ See Data Appendix C for precise definitions and sources.

${ }^{28}$ See also Llavador and Oxoby (2005).
} 
Meissner (2008) and others argue that trade integration causes democratization. We capture this via the dummy variable, gold standard, that is equal to one if a country is on the gold standard and zero otherwise. The idea is that being on the gold standard reduces trade costs and indirectly encourages trade integration. ${ }^{29}$ Thirdly, we include a measure of the size of the population (population) to capture scale effects. All these variables are lagged by five years to reduce the risk of simultaneity bias. Fourthly, Janowitz (1976) and, more recently, Ticchi and Vindigni (2009) and Dincecco (2011) argue that mass conscription armies and war cause democratization. We use the dummy variable, war, that records whether a country was at war in a given year to control for this. World War I was a major shock to the European political and economic order. To capture this and to isolate the effect of the Russian Revolution of 1917 from the effect of the war, we include a dummy variable, WWI, that is equal to one for all countries during the period 1914-18.

\section{Evidence From the Panel Model}

We organize the evidence from the panel model in five sub-sections. We begin with the baseline results. In the next sub-section, we evaluate various sources of bias. This includes a discussion of spatial correlation, the reflection problem, reverse causality, own revolutions, enlightenment shock (one-year time fixed effects), and the effect of the French revolution. This is followed by evidence on auxiliary predictions from the theory and a discussion of other robustness checks. The final sub-section discusses alternative estimation techniques.

\subsection{Baseline Results}

Table 2 reports the baseline results. Columns one to three show the results for the three different measures of the threat of revolution without any control variables (except for the lagged endogenous variable and the fixed effects). The subsequent three columns show the results with the vector of co-variates. In all specifications, the coefficient on the threat of revolution proxy is positive and significant at the

\footnotetext{
${ }^{29}$ The main virtue of this imperfect proxy is that, in contrast to the alternatives considered in section 7 , it can be coded for the entire sample period.
} 
five percent level or better. Moreover, the parameter estimates are stable. Based on the estimate reported in column four, the short-run effect of an extra revolutionary event somewhere in Europe is to increase the franchise by almost two percentage points in the average country. The long-run effect is around 30 percentage points. This baseline result is consistent with the 'threat of revolution hypothesis'.

This estimate represents a causal effect only if the assumption of selection on observables is satisfied. This assumption fails if countries which were ready to democratize for reasons that we do not observe happened to be more exposed to revolutionary shocks from abroad. It is not possible to formally test if this is the case or not, but Altonji et al. (2005) propose a method which can give a sense of how critical selection on unobservables is. The idea is to assume that selection on unobservable factors is as important as selection on the observable factors included in the regression model. Imposing this 'equal selection' assumption enables us explicitly to calculate the magnitude of the selection bias (bias). We can compare this to the point estimate $\widehat{\beta}_{1}$ obtained under the selection on observables assumption (reported at the top of Table 2) and calculate what we shall call the 'selection-ratio' as $\frac{\widehat{\beta}_{1}}{\text { bias }}$. The selection ratio tells us how much stronger selection on unobservables than on observables needs to be for the OLS estimate $\left(\widehat{\beta}_{1}\right)$ to be attributable entirely to selection bias. We report the estimated ratios in bottom row of Table $2 .{ }^{30}$ The ratios range from 2.5 to 5.9. This means that selection on unobservables would have to be 2.5-5.9 times stronger than selection on observables for the baseline result to be entirely explained by selection bias. While perhaps not impossible, we find this highly implausible.

$<$ Table 2: Baseline results $>$

\subsection{Confounding Factors}

In this section, we evaluate various sources of bias, discuss alternative interpretations of the baseline result, and demonstrate the remarkable robustness of the relationship between suffrage and our measures of the threat of revolution.

\footnotetext{
${ }^{30}$ We thank Todd Elder for sharing the relevant STATA code with us.
} 


\subsubsection{Spatial Dependence and the Reflection Problem}

The baseline specifications adjust the standard errors for unrestricted spatial correlation. An alternative, suggested by Conley (1999), is to use a notion of social distance to model spatial dependence. In our context, the most natural notion is geographical proximity. We capture this by the crow-fly distance between pairs of capital cities. Table 3 reports three specifications with 'Conley-adjusted' standard errors based on three different cut-offs for how far apart two countries must be for the spatial correlation to fade to zero. Although the standard errors are higher, the estimated coefficient on $T R_{i t}^{g}$ remains significant at least at the five percent level.

Our emphasis on international diffusion of information naturally brings the socalled reflection problem to mind. The reflection problem refers to the fact that, in general, it is hard to separate contextual effects from social effects (Manski, 1993). This is often a serious obstacle to inference because the object of interest is the size of the social effect. We, however, do not pretend to be able to separate the 'threat' that originates from being located in a geographical area which shares a common threat (a contextual effect) from the 'threat' that originates from the fact that 'peers' are threatened (a social effect).

Yet, Proposition 3 of the model points to a particular form of reflection which we can model. The issue is this: revolutionary events in country 1 may trigger a democratization in country 2. This democratization is observed in country 3 where the elite decide to imitate and also extend the franchise. ${ }^{31}$ This generates an upwards bias in the estimate of $\beta_{1}$ which then reflects a combination of direct and indirect effects of the threat. To separate these effects, we use the variable suffrage reforms abroad, defined as the number of suffrage reforms happening in other countries in the sample in a given year weighted by linguistic distance. If the indirect effect of revolutionary events abroad is important, we expect a positive coefficient on this variable and a reduction in the size of the estimated coefficient on $T R_{i t}^{g}$. Table 3, column four shows that suffrage reforms abroad is insignificant and with the 'wrong' sign. Moreover, the size of the estimated coefficient on $T R_{i t}^{g}$

\footnotetext{
${ }^{31}$ See also Gleditsch and Ward (2006) or Persson and Tabellini (2009).
} 
is unaffected (1.21 versus 1.19). ${ }^{32}$ We obtain similar results with other definitions of suffrage reforms abroad.

We interpret the coefficient on $T R_{i t}^{g}$ as evidence that the 'threat of revolution' affects the franchise extension. It is, however, possible that revolutionary shocks abroad simply reduce uncertainty surrounding the cost of reform at home. This might influence the balance of power within the elite itself and give reform-friendly factions a competitive edge over reform opponents. We can use information on suffrage reform abroad to investigate this possibility. The idea is that if this hypothesis is true, then both revolutionary shocks and the reform experience of other countries should help reform-friendly factions of the elite and make suffrage reform more likely. As noted, we neither find that the direct measure of a 'favorable reform environment' - suffrage reforms abroad - is significant, nor that it has any substantive impact on the coefficient on $T R_{i t}^{g}$.

$<$ Table 3 to appear here $>$

\subsubsection{Reverse Causality}

Suffrage reform in some country may inspire demands for democracy in neighboring countries but with the consequence that the situation gets out of hand and a revolutionary event is triggered. If so, the causality may run from suffrage reform to revolution rather than the other way. We evaluate the plausibility of this alternative interpretation in two ways. First, we introduce a one-year lag in the measures of the revolutionary threat. Table 3 , column five shows a representative specification. The point estimate on $T R_{i t-1}^{g}$ is 1.02 as compared to 1.19 in the baseline, and is significant at the five percent level. A general concern with using one-year lags as a defence against reverse causality is that the residuals might exhibit autocorrelation. In practice, however, the estimated autocorrelation parameter in the error structure in the baseline specification in Table 2, column five is very low (around 0.05) and we explicitly model country-specific AR(1) processes in the error terms. Yet, we consider two alternative ways to engage further with the threat to revolving the reverse

\footnotetext{
${ }^{32}$ When we add suffrage reforms abroad to the event history models discussed in Section 6 , we obtain a positive and significant coefficient. The estimated coefficient on $T R_{i t}^{g}$ remains positive and statistically significant but is smaller.
} 
causality problem with a timing restriction. The first alternative is to model the change in the franchise extension ( $\Delta$ suffrage) rather than its level (suffrage). The point is that specifications with $\Delta$ suffrage are less prone to autocorrelation in the error structure. ${ }^{33}$ Table 3, column seven reports that the estimated coefficient on $T R_{i t-1}^{g}$ is 1.26 and significant at the one percent level in a regression with $\Delta$ suffrage as the dependent variable. The second alternative is to estimate an event history model. This is discussed in detail in Section 6. An event study model uses information on the timing of the reforms only. In our data, these reforms are spread out over time within a country and never occur in consecutive years in any country. This reduces the problem of autocorrelation. It is reassuring that the point estimate on $T R_{i t-1}^{g}$ is also positive and significant in these models (see Table 8 in Section 6).

Second, the frequency of our data is yearly. Revolutionary events and suffrage reforms happening in the same year are, therefore, coded as if they were simultaneous events. In reality, of course, they were not and it is instructive to look at the timing within a year. Table 4 shows for each of the years associated with a major revolutionary event, the date of the onset of the event or events (column two) and the date at which the suffrage concession was announced in the affected countries (column three). In some cases, the reforms were announced or conceded the year before they were actually adopted (which are the years recorded in Table 1 and repeated in bracket in Table 4). An example of this is Denmark in 1848 where the Danish King announced his willingness to broaden the franchise on March 18 1848, but the new constitution was not signed till June 5 1849. Another example is United Kingdom in 1918. The process that led to the fourth reform act arguably started in 1912 with the proposed Franchise and Distribution Act.

For the three first waves in 1820, 1830 and 1848, we observe that revolutionary events systematically preceded the suffrage reforms. The only exception is Switzerland. Here, the constitutional process triggered by the civil war of 1847 started before the revolution in France but can hardly be considered the cause of the 1848 revolutions. ${ }^{34}$ The Russian revolution of 1905 preceded the reform process in Fin-

\footnotetext{
${ }^{33}$ The estimated autocorrelation parameter is 0.005 with two-year fixed effects and 0.0028 with one-year effects.

${ }^{34}$ Berger and Spoerer (2001, p. 320) "conclude that without the economic crisis of 1845-1848, ..., there would not have been the critical mass to support these new ideas" and thus attribute
} 
land. The timing in the turbulent years around World War I is a little less clear-cut, but the reforms in the Netherlands, Sweden, Norway, Italy and Belgium clearly followed after the Russian revolution of 1917 and the revolution in Hungary in 1918. The constitutional reform in Germany - leading to the Weimar Republic - also follows after the two major revolutionary events. Based on the evidence recorded in Table 4 and on the detailed narrative provided by Weyland (2010), we find it implausible that the baseline result is due to reverse causality. The timing and historical narrative are simply not consistent with this.

$<$ Table 4 to appear here $>$

\subsubsection{Own Revolutions}

Our coding of the threat revolution variables exclude revolutionary events that happened within a country. The reason for not doing so is that we are using the diffusion of information about revolutions that happened elsewhere to estimate the impact of the threat of revolution. Revolutions that actually happened within a country is an impulse to the process not a consequence of it. In practice, it is only France who had 'own revolutions' within the Western European sample. An objection to our choice of excluding these events is that we are confounding revolutions in France with revolutions elsewhere. We can deal with this by controlling directly for 'own revolutions' in the regressions. Table 3, column six reports a specification where we add the dummy variable own revolution which is equal to one for France in 1830 and 1848. We observe that the coefficient on $T R_{i t}^{g}$ is largely unaffected. The French revolutions of 1830 and 1848 themselves were related to franchise extensions in France and so the coefficient on own revolution is positive and significant. In conclusion, we can rule out that the baseline results are driven by our coding of the revolution variables.

\subsubsection{Enlightenment Shocks}

It is possible that revolution and suffrage reform were both driven by liberal ideas sweeping the continent, and our results could be interpreted as evidence of such the 1848 revolution to economic shocks. 
simultaneous over-time change in the revolutionary mood and franchise extension caused by 'enlightenment shocks'. The publication of important books, such as Alexis de Tocqueville's Democracy in America from 1835, von Humboldt's The Limits of State Action from 1851, John Stuart Mill's On Liberty from 1859, or Karl Marx and Friedrich Engels' Manifesto of the Communist Party from 1848, could, for example, induce such spurs of enlightenment.

All the baseline specifications include time fixed effects to control for common enlightenment shocks at the two-year frequency but it is, of course, possible that these shocks happened at the yearly frequency. ${ }^{35}$ The reason for using two-year time fixed effects is that doing so enables us to estimate panel corrected standard errors with unrestricted spatial correlation. We cannot model unrestricted spatial correlation in the error structure if we include one-year time fixed effects. The problem is multicollinearity: one-year time and country fixed effects can explain 98 percent of the variation in the unweighted proxy for the threat of revolution $\left(T R_{i t}^{u}\right)$ and 87 percent of the variation in the distance weighted measure $\left(T R_{i t}^{g}\right)$. Since we do not include one-year time fixed effects in our baseline models, we may not be controlling adequately for enlightenment shocks.

To gauge whether this is the case or not, we carry out additional estimations and tests. Firstly, we demonstrate that the results obtained with the distance weighted proxy for the threat of revolution $\left(T R_{i t}^{g}\right)$ are robust to including one-year time fixed effects. As noted, we cannot obtain standard errors that correct for unrestricted spatial correlation in this case. We can, however, obtain both clustered standard errors corrected for panel heteroscedasticity and Conley-adjusted standard errors which use crow-fly distance between capital cities to model spatial dependency. Table 5 reports two sets of results. ${ }^{36}$ Columns 1 to 3 show, for ease of comparison,

\footnotetext{
${ }^{35}$ In Data Appendix D in the supplementary material, we show that the baseline results are unaffected if we cluster the standard errors by year (or by two-year pairs).

${ }^{36}$ The models reported in Table 5 control for the variable own revolution. We include this variable for two reasons. First, we show in Table 3, column six that the variable is highly significant. Second, it is arguably more important to control for own revolution with one-year than with twoyear time fixed effects. Table 4 demonstrates that France had "own" revolutions in 1830 and 1848 which led to subsequent franchise extensions. If we do not control for these, they will be absorbed by the one-year time fixed effects. This overestimates the importance of these time fixed effects, and makes it harder to distinguish them from $T R_{i t}^{g}$ or $T R_{i t-1}^{g}$. As expected, we obtain smaller coefficient estimates on the threat of revolution variables if we exclude own revolution. Precision is also reduced, but the point estimates on $T R_{i t-1}^{g}$ remains statistically significant at the five
} 
estimations that control for two-year time fixed effect effects. Columns four to six show estimations that control for one-year time fixed effects. Column four shows that the point estimate on $T R_{i t}^{g}$ is equal to 1.03 and significant at the 10 percent level. This is a little smaller and less precisely estimated than with two-year effects (reported in column one). Column five shows a specification with a one-year lag of $T R_{i t}^{g}$. The estimated coefficient on $T R_{i t-1}^{g}$ is equal to 1.10 and significant at the five percent level. Column six reports on a specification where the outcome variable is $\Delta$ suffrage. In this first difference model, the estimated coefficient on $T R_{i t-1}^{g}$ is 1.37 and significant at the one percent level. In both cases, the point estimate is slightly smaller than the one obtained with two-year year fixed effects.

Secondly, a classic solution to a multicollinearity problem is to expand the sample. We cannot do this for the panel model that uses suffrage as the outcome variable. It is, however, possible to expand the sample in the context of the event history study where we use the dummy reform as the outcome variable. As discussed in Section 6.2 in more detail, in that framework, we can estimate a linear probability model which includes two-way fixed effects, with time fixed effects defined at the yearly frequency, for the extended sample of 17-21 countries. We find that the estimated coefficient on $T R_{i t}^{g}$ is positive and significant at the ten percent level evaluated with standard errors that allow for unrestricted spatial correlation. Moreover, the coefficient is similar to the one obtained without one-year time dummies. This suggests that we are not merely capturing enlightenment shocks with the threat of revolution proxies.

Thirdly, another way to deal with multicollinearity is to increase cross-sectional variation in the data. In Section 5.3, we test two auxiliary hypotheses generated by 'the threat of revolution hypothesis'. Both of them induce more cross-sectional variation in the threat of revolution proxies by introducing interactions, either by postulating that the revolutionary events are likely to have stronger effects on countries that are close to where the event takes place or by postulating that the threat of revolution is conditional on inequality. Both hypotheses receive support with one-year fixed effects.

percent level. 
Taken together these estimations do not suggest that the baseline results from Table 2 simply capture yearly time shocks and demonstrate that our results are robust to yearly enlightenment shocks. The one-year time fixed effects are, however, an inadequate defense against country-specific time varying 'enlightenment shocks'. To capture such shocks, we draw on the work of Potrafke and Vaubel (2011) on European 'authors of liberty'. 'Authors of liberty' are scholars, poets, journalists, politicians, civil servants, etc. who during their life-time were influential supporters of liberal or radical ideas. Examples include Stefan Zweig, John Stuart Mill, Victor Hugo, Max Weber, Jakob Mey, and 366 others selected by a panel of country experts and listed in the Appendix to Potrafke and Vaubel (2011). Based on these data, we construct two country-specific time-varying enlightenment indicators. The first, $\mathrm{AL}_{i t}^{\text {Home }}$, records the number of 'authors of liberty' who live in country $i$ in year $t$. The second, $\mathrm{AL}_{i t}^{A b r o a d}$, records the number of such authors from country $i$ who live abroad (often because they emigrated in response to repression at home) in year $t$, both measured per 1000 inhabitants. We conjecture that these 'authors of liberty' serve as exponents of liberal ideas at home and, if living abroad, that they provide a hub through which new liberal ideas developing abroad can be transmitted to liberal-minded connections in their home country. Re-estimating the panel model with $\mathrm{AL}_{i t}^{\text {Home }}$ and $\mathrm{AL}_{i t}^{\text {Abroad }}$ added, we find that ${ }^{37}$

$\mathrm{suffrage}_{i t}=\underset{(0.014)}{0.94 \mathrm{suffrage}_{i t-1}}+. .+\underset{(0.18)}{1.32 T} R_{i t}^{g}+. .+\underset{(0.98)}{1.20 A L_{i t}^{\text {Abroad }}}+\underset{(1.58)}{0.46 A L_{i t}^{\text {Home }}}+.$.

The coefficients on the two enlightenment indicators are positive, as expected, but not statistically significant. More importantly, the coefficient on $T R_{i t}^{g}$ continues to be highly significant and is a little larger than previously. All in all, we find it unlikely that the positive baseline estimate of $\beta_{1}$ simply reflects confounding 'enlightenment shocks'. Enlightenment might have been part of the story, but so was the threat of revolution.

$<$ Table 5 to appear here $>$

\footnotetext{
${ }^{37}$ The (unreported) control variables are the same as in Table 2, column five. The standard errors reported in brackets under the coefficients allow for unrestricted spatial correlation, within country clustering, and panel heteroskedasticity.
} 


\subsubsection{The French Revolution and the Napoleonic Wars}

In the years after 1792, the French army occupied a number of neighboring countries (or parts thereof) and imposed the French civil code and eliminated aristocratic privileges (Acemoglu et al. 2011). This attempt to 'export' the French revolution by force might have lingered in the backs of the minds of the European elites in the decades that followed. They might, therefore, have reacted to the revolutionary events in France (and elsewhere) in 1830 and 1848, not out of fear that they too were at risk of a revolution, but because they feared another attempt at exporting revolutionary ideas by force. If so, the positive correlation between the threat of revolution proxies and suffrage reform could reflect an attempt by the elites in other countries to diffuse such a threat by copying the political system of the country where the revolution originated. This alternative explanation, however, presumes that such a move would effectively preempt an invasion. This would only be the case if the main objective of such an invasion was to export revolutionary ideas and institutions. This appears implausible and, moreover, this alternative interpretation is not consistent with the interaction between inequality and the threat of revolution proxies reported below in Section 5.3.

\subsubsection{Repression, Transfers and Business Cycle Shocks}

The 'threat of revolution hypothesis' views repression or the promise of transfers as alternative ways to deal with the threat of revolution (see e.g. Acemoglu and Robinson, 2000, 2006). Logically, therefore, repression and transfers are negatively correlated with the franchise extension but positively correlated with the threat of revolution. Consequently, the estimate of $\beta_{1}$ is biased downwards. The reason we do not correct for this bias in the baseline is data limitations. We can, however, at the cost of reducing the sample size obtain some rudimentary proxies for repression and transfers. As a proxy for 'repression', we use the share of the public budget spent on policing and defense (repression) and as a measure of 'fiscal transfers', we use the share of the public budget spent on health, education, housing and various government-sponsored insurance and welfare programs (fiscal transfers). Table 6, columns one and two report some estimations that control for these factors. 
Despite the loss of observations, the threat of revolution variable continues to have a significant and positive effect on suffrage. The point estimates on repression and fiscal transfers are negative, as predicted by the theory, but not statistically significant. ${ }^{38}$

Economic hardship is likely to be negatively correlated with revolutionary threats. Insofar as the business cycle has an international component, this may also bias the estimate of $\beta_{1}$ downwards. To evaluate the importance of this, we extract the cyclical component of GDP per capita, cycle, using a Hodrick-Prescott filter. Column three of Table 6 reports a specification with cycle and the trend component of GDP per capita, trend. The point estimate on $T R_{i t}^{g}$ is smaller, as one would expect if the cycle is negatively correlated with the threat of revolution and positively correlated across countries, but its significance is unaffected. The effect of cycle itself is insignificant. It is, however, questionably if the quality of the historical GDP data is sufficient to capture the business cycle element accurately. The problem is that the GDP data for the period is often constructed using incomplete data for subsets of sectors and years. An alternative proxy for the cycle is to use year-on-year variation in rainfall. This has been shown by, for example, Berger and Spoerer (2001), Miguel et al. (2004), Brückner and Ciccone (2011), Burke and Leigh (2010) and Franck (2014) to be a good predictor of economic activity in economies with a large agricultural sector and to predict social unrest in Aidt and Leon (2014). Using data from Casty et al. (2007), we code two variables, rainfall, and rainfall growth. They measure the logarithm of the yearly rainfall and the year-on-year change in rainfall. We focus on the period before World War I since the Western European economies were more agrarian then. In column four of Table 6, we include the contemporaneous and the lagged value of rainfall as in Brückner and Ciccone (2011), while in column five, we follow Miguel et al. (2004) and use rainfall growth and its lagged value. The coefficients on the rainfall variables are positive, but not statistically significant. The estimated effect of the threat of revolution is hardly affected.

\footnotetext{
${ }^{38}$ Re-estimating the specifications without repression and fiscal transfers on the restricted sample makes almost no difference to the point estimate on $T R_{i t}^{g}$. This suggests that the downward bias is small. It makes no difference to the results if we control for repression and fiscal transfers abroad in the estimations [not reported].
} 
$<$ Table 6 to appear here $>$

\subsection{Tests of Auxiliary Hypotheses}

The 'threat of revolution hypothesis' delivers two auxiliary predictions that we test. Firstly, information about revolutionary threats diffuse across borders and agents in other countries learn about the risks and opportunities at home from events happening abroad. This learning effect is likely to be stronger amongst pairs of countries which are geographically, economically, or culturally closer. By distinguishing common time variation in the threat of revolution from cross-country variation generated by differences in geographical or linguistic distance to the epicenter of each revolutionary event, we can test this prediction. ${ }^{39}$ Specifically, we decompose the threat measure as follows:

$$
\widetilde{T R}_{i t}^{g}=\widetilde{\beta}_{1} \sum_{j \neq i} R_{j t}+\widetilde{\gamma} \sum_{j \neq i} D_{i j} R_{j t} .
$$

The first term captures over-time variation in the threat level that is common to all countries and we expect that $\widetilde{\beta}_{1}>0$. The second term isolates the cross-country variation generated by differences in distance to the events. This source of variation is plausibly exogenous and we expect that $\widetilde{\gamma}<0$. Re-estimating the panel model with $\widetilde{T R}_{i t}^{g}$ instead of $T R_{i t}^{g}$, we find that in a specification with two-year time fixed effects $^{40}$

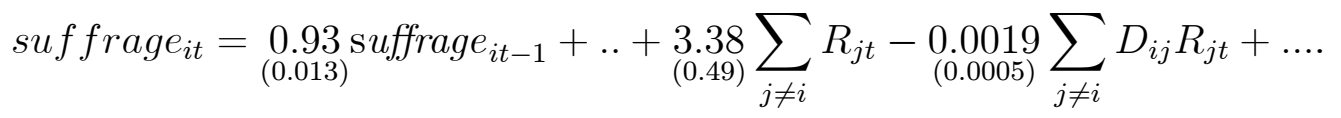

The estimate of $\widetilde{\gamma}$, which is identified purely from the cross-country variation generated by distance to the revolutionary events, is negative and statistically significant. This suggests that the revolutionary shocks had a larger effect in countries closer to the epicenter of each event. Moreover, we have re-estimated this specification with one-year time fixed effects. ${ }^{41}$ The estimate of $\widetilde{\gamma}$ is equal to -0.0035 and is

\footnotetext{
${ }^{39}$ Cross-country variation is also created by the fact that we omit revolutionary events happening within a country itself. This variation is non-random. Since this only affects France (in 1830 and 1848), we check that excluding France makes no difference to the results [not reported]. We also note that the results are robust to controlling for the variable own revolution (see Table 3 , column six).

${ }^{40}$ The (unreported) control variables are the same as in Table 2, column five. The standard errors reported in brackets under the coefficients allow for unrestricted spatial correlation, within country clustering, and panel heteroskedasticity.

${ }^{41}$ With one-year time fixed effects, we cannot identify $\widetilde{\beta}_{1}$.
} 
statistically significant.

Secondly, the 'threat of revolution hypothesis' predicts that the elites are more inclined to seek alternatives to franchise extension when they consider democratization threatening. Democratization is arguably more threatening where inequality is high because this enhances the incentive of newly enfranchised voters to support state-sponsored redistribution. Reliable historical data on income inequality is scarce. However, from the work by Bourguignon and Morrisson (2002), we obtain data on the gini coefficient for a subset of countries. We test this auxiliary hypothesis by adding the gini coefficient, gini, and the interaction between gini and $T R_{i t}^{g}$ to the model. This creates additional cross sectional variation in the effect of $T R_{i t}^{g}$ and allows us to include one-year time fixed effects. The result is: ${ }^{42}$

$\mathrm{suffrage}_{i t}=\underset{(0.013)}{0.93} \mathrm{~s}_{\mathrm{uffrage}} \mathrm{e}_{i t-1}+. .+\underset{(5.73)}{15.95 T} R_{i t}^{g}+. .+\underset{(27.10)}{40.15} \mathrm{gini}_{i t-5}-\underset{(10.91)}{29.96}\left(\mathrm{gini}_{i t-5} \times T R_{i t}^{g}\right)+.$.

The negative and statistically significant coefficient on the interaction term suggests that as a country's income distribution becomes less unequal, the elites become more willing to respond to the threat of revolution by extending the franchise. The coefficient on gini is not statistically significant. ${ }^{43}$ The two auxiliary tests are consistent with our interpretation of the baseline result as evidence in favor of the 'threat of revolution hypothesis'.

\subsection{Other Robustness Checks}

Table 5 reports the results from three additional robustness checks. ${ }^{44}$ First, the baseline specification uses the sub-set of major revolutionary events recorded in boldface in Table 1. In column six, we report a representative specification that uses all the recorded events. The coefficient of $T R_{i t}^{g}$ is smaller, but continues to

\footnotetext{
${ }^{42}$ The (unreported) control variables are the same as in Table 2, column five. The standard errors reported in brackets under the coefficients allow for within country clustering, and panel heteroskedasticity. There is not sufficient cross section variation to allow for unrestricted spatial correlation in the error structure, but using the Conley-adjusted standard errors yield similar results. We obtain similar results with the other proxies [not reported].

${ }^{43}$ Acemoglu and Robinson (2000), Boix (2003), and Ansell and Samuels (2010) stress that inequality may affect the franchise, although there is no agreement on the nature of the effect. The observed range for gini is 0.47 to 0.56 . For the average value of gini (0.52) the (short-run) marginal effect of $T R^{g}$ on suffrage is around 1.38.

${ }^{44}$ Appendix D in the supplementary material contains more robustness checks.
} 
be significant at the one percent level. This is not surprising since the minor revolutionary events are associated with less informative signals. Second, the wave of reforms between 1915 and 1919, arguably, were different from those happening during the long 19th century. To check that the results are not influenced unduly by this, we report in column seven, a specification where we restrict the sample to the period from 1820 to 1913. This makes almost no difference. Third, Italy, Austria and Germany drop out of the sample when they become dictatorships during the interwar years. In column eight, we show a specification where we keep Italy and Germany until 1938. ${ }^{45}$ This has almost no effect on the point estimate.

\subsection{Alternative Estimation Techniques}

In the baseline specifications, we adopt an OLS estimator and adjust the standard errors to take unrestricted spatial correlation, within country interdependency (clustering by country), and panel heteroskedasticity into account. In Table 7, we report results obtained by alternative estimation techniques. Firstly, to get a sense of how much the adjustment for spatial correlation and clustering in the error structure matters, we report in columns one to three specifications which do not correct for spatial correlation or for clustering (column one), correct for spatial correlation, but not for clustering (column two), or corrects for clustering but not for spatial correlation (column three), respectively. ${ }^{46}$ Clustering by country has little effect on the standard errors. In contrast, modeling spatial correlation improves precision. In all cases, the point estimate on $T R_{i t}^{g}$ (which is not affected by the various adjustments) is statistically significant at the one percent level.

Secondly, we are aware that the lagged dependent variable may cause a Nickell bias, albeit with more than 100 years of data the bias is likely to be small. ${ }^{47}$ The GMM-system estimator (Blundell and Bond, 1998) or the bias-corrected leastsquares dummy variable (LSDV) estimator (Bruno, 2005) can correct this bias, if there is one. ${ }^{48}$ Very similar results emerge with these estimators (columns three

\footnotetext{
${ }^{45}$ Suffrage is equal to zero during years with dictatorship. Austria is not included post-1918 due to incomplete urbanization data. Results are similar when urbanization rate is excluded and Austria is included till 1938 [not reported].

${ }^{46}$ All estimations include country and two-year time fixed effects and allow for heteroskedasticity.

${ }^{47}$ Judson and Owen (1999) show that the bias is negligible with more than 20 years.

${ }^{48}$ With only 12 countries, the advantage of the GMM estimator is unclear.
} 
and four).

Thirdly, since all countries in the 'Western European sample', with the exception of the United Kingdom and France, did not have regular elections by 1820 (suffrage is coded zero) and all countries had universal male suffrage towards the end of the sample period (suffrage is coded 100), suffrage is a censored outcome variable. We can use the Tobit estimator or the fractional estimator, suggested by Papke and Wooldridge (1996) to take this into account. From the results reported in columns five and six of Table 7, we see that it does not make any difference to the significance of the results.

Finally, suffrage as well as several of the control variables are trending up and may be non-stationary. We have reformulated the model as an Error Correction Model and find similar results (reported in Appendix D).

$<$ Table 7 to appear here $>$.

\section{Evidence From the Event History Model}

The panel model tests whether the threat of revolution affected the degree of democracy. The event history model tests whether the threat of revolution can explain the timing of suffrage reform.

\subsection{The 'Western European Sample'}

Table 8 reports logit estimates of the effect of the threat of revolution variables on the probability of suffrage reform. We observe that the estimates are positive and statistically significant at the one percent level (columns one to three). A similar result is obtain with the one-year lag of $T R_{i t}^{g}$ (column four). Based on the estimate reported in column one, one extra revolutionary event increases the odds that a country will introduce a major suffrage reform in that year by 75 percent. This is a substantial effect which is consistent with the 'threat of revolution hypothesis'. The specification in column five shows that suffrage reforms in neighboring countries have a positive and significant effect on the probability of suffrage reform in a given country. This is also consistent with the prediction of the theory (proposition 3 ). 
As expected, controlling for this indirect channel reduces the point estimate on $T R_{i t}^{g}$ but not its statistical significance.

We have undertaken many robustness checks. Firstly, suffrage reforms are rare events. To correct for this, we have re-estimated all specifications using the rare events logit estimator (King and Zeng, 2001). The representative result reported in column six shows that the coefficient on $T R_{i t}^{g}$ continues to be statistically significant at the one percent level after the bias-correction and that the coefficient estimate is only marginally smaller. Secondly, we treat all franchise extensions as if they were nonreversible. We know that in some cases they were not. Using the coding of franchise contractions from column four of Table 1, we make a distinction between those reforms that lasted for at least ten years and those which were wholly or partly reversed within that time window. Column seven shows a specification that excludes suffrage extensions that were followed by a franchise contraction. The coefficient on $T R_{i t}^{g}$ is smaller, but continues to be statistically significant at the one percent level. Thirdly, column eight shows a specification with country-specific hazard rates. ${ }^{49}$ The point estimate is larger than the corresponding estimate reported in column two and is significant at the one percent level. Finally, we have investigated specifications that control for the cyclic component of GDP, or spending on repression and fiscal transfers. In all cases, the estimate of the threat of revolution variable is significant. ${ }^{50}$

$<$ Table 8 to appear here $>$

\subsection{The 'Broader European Sample'}

All the countries in the 'Western European sample' achieved universal manhood suffrage within the sample period. In other parts of Europe, in particular in Eastern Europe, on the Balkans, and on the Iberian peninsula, the evolution of democracy was more sporadic and many countries did not become fully consolidated democracies until the 1990s. Yet, they did take the first steps towards democracy by extending the franchise to broader segments of the populations before World War

\footnotetext{
${ }^{49}$ These are estimated by conditional fixed effects logit. Results from a random effects model are similar [not reported].

${ }^{50}$ See Table D1 in Appendix D included with the supplementary material.
} 
I or just after, following a pattern not all that dissimilar to the one followed in Western Europe (Seymour and Frary, 1918). Consequently, seen from the perspective of the 19th century, it is not so clear that our sample of Western European countries is systematically different from the 'full' European sample. Nevertheless, it is important to test the 'threat of revolution hypothesis' on a broader sample.

To this end, we add information on suffrage reforms in Spain, Portugal, Greece, Iceland, Luxembourg, Serbia, Hungary, Poland, Russia, and Romania to the sample. The down-side is that we can, due to data limitations, only control for the influence of war (war and WW1), and, in a few countries, for GDP per capita and population. Table 9 reports the results for the maximum sample of 21 countries (columns one to four). The last four columns report specifications with additional control variables, but fewer countries and less time coverage. We observe that the threat of revolution (measured by $T R_{i t}^{g}$ ) has a positive impact on the likelihood of suffrage reform. Moreover, it is evident that the significance and magnitude of the effect is independent of the estimation technique and coding choices. The historical narrative clearly demonstrates that repression was common currency in Russia and Eastern Europe. Since we cannot control for this, we expect a downwards bias. It is, therefore, not surprising that the estimated effects are smaller in magnitude than those reported for the 'Western European sample' in Table 7.

$<$ Table 9 to appear here $>$

As discussed in Section 5.2.4, $T R_{i t}^{g}$ and the other measures of the threat of revolution are highly correlated with one-year time fixed effects. With the 'broader European sample', we have up to 21 countries. The extra countries makes it feasible to overcome the multicollinearity problem. ${ }^{51}$ In particular, we estimate a linear probability model with country and one-year time fixed effects as well as unrestricted spatial correlation in the error structure. The result is: ${ }^{52}$

\footnotetext{
${ }^{51}$ One-year dummies and country fixed effects now explain 80 percent of the variation in $T R_{i t}^{g}$ in the enlarged sample. They explain 98 percent of the variation in the $T R_{i t}^{u}$ making estimation infeasible with this proxy.

${ }^{52}$ The standard errors reported in brackets under the coefficients allow for unrestricted spatial correlation, within country clustering, and panel heteroskedasticity.
} 


$$
P\left(\text { reform }_{i t}=1 \mid T R_{i t}^{g}, X_{i t}, M_{t-1}=0\right)=\ldots \underset{(0.01675)}{0.032} T R_{i t}^{g}+\underset{(0.035)}{0.0137 \text { war }_{i t}}
$$

The coefficient on $T R_{i t}^{g}$ is significant at the ten percent level. While the year dummies are significant, they do not seem to matter much for the point estimate which is 0.028 when the year dummies are excluded. We also note that we get similar results when we control for GDP per capita and population. To reiterate, these results reinforce our interpretation of the baseline results as evidence of threat of revolution rather than of enlightenment shocks.

\section{Other Results}

Our regressions include a number of control variables motivated by other theories of suffrage reform than the 'threat of revolution hypothesis'. We stress that our study is not designed explicitly to test these alternatives. The purpose of including these variables is to avoid confounding our estimate of threat of revolution effect in obvious ways. Yet, it is of independent interest to consider the findings related to these variables and to dig a little deeper by augmenting the baseline models estimated on the 'Western European sample' with additional variables for which we only got partial time or country coverage. Table 10 combines the additional results from the panel model and the event history study.

In the baseline specifications, we use the variable gold standard to proxy for trade integration and we find little support for the 'trade-causes-democracy' thesis. The two variables trade volume (the sum of imports and exports relative to GDP) and wheat price spread capture trade integration more directly. ${ }^{53}$ The variable wheat price spread is a measure of trade costs based on convergence in wheat prices across time and space (Jacks, 2005). The coefficient on trade volume is positive, but not significant (column one and five). On the other hand, wheat price spread is significant in the event history model (column six). This gives some credence to the 'trade-causes-democracy' thesis.

The modernization variables-GDP per capita, urbanization rate, and education

\footnotetext{
${ }^{53}$ We lose between 200 and 650 observations when we include these variables.
} 
attainment-are mostly insignificant, with the exception that GDP per capita is significant in the event history model (see Table 8). The same message comes from the specifications shown in columns three and seven of Table 10 where we control for the impact of industrialization (agricultural share). This echoes the findings of Acemoglu et al. (2008) that rising income and education levels cannot explain democratization. ${ }^{54}$ Occasionally, population size has a positive and significant impact.

The 'Janowitz thesis' that war in general and conscription armies in particular were important impulses for democratic reform receives some support. In the panel model, the coefficient on war is consistently positive and significant. Based on the point estimates reported in Table 2, being at war increases suffrage by between 3.2 and 4.3 percentage points in the short run, with the long-run effect being about 17 times larger. The effect is, however, not significant in the event history study (see, e.g., Table 8). To take the scale of war into account, we use a measure of the number of war deaths-war intensity. We obtain results that are qualitatively similar to those obtained with the dummy variable war (columns four and eight of Table 10). The dummy variable for World War I is not significant, except in the conditional fixed effects logit model reported in Table 8, column eight.

$<$ Table 10 to appear here $>$

\section{Conclusion}

We provide robust econometric evidence that the threat of revolution was systematically related to the evolution of suffrage rights in Europe in the 19th and early 20th centuries. This is consistent with the 'threat of revolution hypothesis' and the framework for understanding democracy change developed by Acemoglu and Robinson (2000, 2006).

Yet, it is important to keep three points in mind. Firstly, by focusing on Europe during the first wave of democratization, we study a subset of the universe of all suffrage reforms. It is, therefore, possible that the threat of revolution played a

\footnotetext{
${ }^{54}$ For evidence supporting 'modernization theory', see, e.g., Gundlach and Paldam (2009) and for a critical evaluation, see Przeworski and Limongi (1997).
} 
different role for democratization elsewhere and that other theories might have greater explanatory power in other contexts, regions, or time periods. The work by Przeworski (2009) on the causes of suffrage reforms after World War I, the work by Aidt and Franck $(2013,2014)$ on the relationship between the Swing riots and support for the Great Reform Act in 1832 in Great Britain, and the work by Aidt and Leon (2014) on the causal relationship between economic shocks, riots and democratic change in Africa at the turn of the 20th century, however, give some reason to believe that the 'threat of revolution hypothesis' offers insights into the causes of suffrage reforms also outside our sample and for particular reforms inside our sample.

Secondly, Acemoglu and Robinson's (2000, 2006) theory of democratization emphasizes that democratization happens at critical junctures in history. Our evidence support this interpretation. However, this does not rule out that complex interactions between underlying, slow-moving economic variables-industrialization, urbanization, income growth, international trade, inequality, etc.-and democratic triggers could be important, and nor does the theory rule this out. One can interpret the revolutions abroad as shocks that may push a country over a threshold, but only if the underlying fundamentals are such that the economy is 'close' to the threshold to begin with.

Third, we interpret revolutionary chocks as signals to the elites in other countries about the threat of revolution. It is, however, possible that revolutions abroad also capture signals about the cost of reform to factions within a divided 'elite'. Revolutions abroad might give those in favor of reform, a bargaining chip vis-à-vis the reform opposition because they can threaten to encourage a domestic revolt or simply because they can 'bully' opponents within the elite into action with an argument that reform is needed to avoid a revolution. In this case, the relationship between franchise extension and the threat of revolution variables does not capture a direct threat effect. Instead, it captures an indirect threat effect through which the hand of reform-friendly factions within the elite is strengthened. Suffrage reform is then caused by a mixture of preemptive and proactive forces. 


\section{References}

[1] Acemoglu, D., Robinson, J.A., 2000. Why did the west extend the franchise? Democracy, inequality, and growth in historical perspective. Quarterly Journal of Economics 115, 1167-1199.

[2] Acemoglu, D., Robinson, J.A., 2006. Economic Origins of Dictatorship and Democracy. Cambridge University Press, Cambridge, UK.

[3] Acemoglu, D., Johnson, S., Robinson, J.A., 2001. The colonial origins of comparative development: an empirical investigation. American Economic Review 91, 1369-1401.

[4] Acemoglu, D., Johnson, S., Robinson, J.A., Yared, P., 2008. Income and democracy. American Economic Review 98(3), 808-842.

[5] Acemoglu, D., Cantoni, D., Johnson, S., Robinson, J.A., 2011. The consequences of radical reform: the French Revolution. American Economic Review 101, 3286-3307.

[6] Aidt, T.S., Daunton, M., Dutta, J., 2010. The Retrenchment hypothesis and the extension of the franchise in England and Wales. Economic Journal 120, 990-1020.

[7] Aidt, T.S., Albornoz, F., 2011. An economic theory of political institutions: foreign intervention and overseas investments. Journal of Development Economics 94, 192-201.

[8] Aidt, T.S., Franck, R., 2013. How to get the snowball rolling and extend the franchise: Voting on the Great Reform Act of 1832. Public Choice 155, 229-250.

[9] Aidt, T.S., Leon, G., 2014. The democratic window of opportunity: evidence from riots in sub-Saharan Africa. Journal of Conflict Resolution. In Press.

[10] Aidt, T.S., Franck, R., 2014. Democratization under the threat of revolution: evidence from the Great Reform Act of 1832. Mimeo, Faculty of Economics, University of Cambridge, UK.

[11] Altonji, J., Todd, G., Elder, E., Taber, C.R., 2005. Selection on observed and unobserved variables: assessing the effectiveness of Catholic Schools. Journal of Political Economy 113, 151-184.

[12] Andrews, J.T., Jackson, R.W., 2005. Strategic fools: electoral rule choice under extreme uncertainty. Electoral Studies 24, 65-84.

[13] Ansell, B., Samuels, D., 2010. Inequality and democratization: a contractarian Approach. Comparative Political Studies 43, 1543-1574.

[14] Beck, N., Katz, J.N., 1995. What to do (and not to do) with time-series crosssection data. American Political Science Review 89, 634-647.

[15] Beck, N., Katz, J.N., Tucker, R., 1998. Taking time seriously: time-seriescross-section analysis with a binary dependent variable. American Journal of Political Science 42, 1260-1288.

[16] Berger, H., Spoerer, M., 2001. Economic crisis and the European revolutions of 1848. Journal of Economic History 61, 293-326. 
[17] Bertrand, M., Duflo, E., Mullainathan, S., 2004. How much should we trust differences-in-differences estimates? Quarterly Journal of Economics 119, 249275 .

[18] Blundell, R., Bond, S., 1998. Initial conditions and moment restrictions in dynamic panel data models. Journal of Econometrics 87, 115-143.

[19] Boix, C., 2003. Democracy and Redistribution. Cambridge University Press, Cambridge, UK.

[20] Bourguignon, F., Morrisson, C., 2002. Inequality among world citizens 18201992. American Economic Review 92, 727-744.

[21] Brock, M., 1973. The Great Reform Act. Hutchinson University Library, London.

[22] Bruno, G.S.F., 2005. Estimation and inference in dynamic unbalanced paneldata models with a small number of individuals. The Stata Journal 5, 473-500.

[23] Brückner, M., Ciccone, A., 2011. Rain and the democratic window of opportunity. Econometrica 79, 923-947.

[24] Burke, P., Leigh, A., 2010. Do output contractions trigger democratic change? American Economic Journal: Macroeconomics 2, 124-157.

[25] Casty, C., Raible, C.C., Stocker, T.F., Wanner, H., Luterbacher, J., 2007. A European pattern climatology 1766-2000. Journal Climate Dynamics 29, 791805 .

[26] Chaney, E., 2013. Revolt on the Nile: economic shocks, religion and political power. Econometrica 81, 2033-2053.

[27] Collier, R.B., 1999. Paths Toward Democracy. The Working Class and Elites in Western Europe and South America. Cambridge Studies in Comparative Politics. Cambridge University Press, Cambridge, UK.

[28] Congleton, R.D., 2007. From royal to parliamentary rule without revolution: the economics of constitutional exchange within divided governments. European Journal of Political Economy 23, 261-284.

[29] Congleton, R.D., 2011. Perfecting Parliament. Cambridge University Press, Cambridge, UK.

[30] Conley, T.G., 1999. GMM estimation with cross sectional dependence. Journal of Econometrics 92, 1-45.

[31] Conley, J.P., Temini, A., 2001. Endogenous enfranchisement when groups' preferences conflict. Journal of Political Economy 209, 79-102.

[32] Dincecco, M., 2011. Political Transformations and Public Finances, Europe 1650-1913. Cambridge University Press, Cambridge, UK.

[33] Dorsch, M.T., Maarek, P., 2014. Inefficient Predation and Political Transitions, Mimeo, Central European University Budapest.

[34] Ellis, C.J., Fender, J. 2011. Information cascades and revolutionary regime transition. Economic Journal 121, 763-792.

[35] Engerman, S.L., Sokoloff, K.L., 2012. Economic Development in the Americas since 1500. Endowments and Institutions. Cambridge University Press, Cambridge, UK. 
[36] Esteban, J., Mayoral, L., Ray, D., 2012. Ethnicity and conflict: an empirical investigation. American Economic Review 102, 1310-1342.

[37] Falkinger, J., 1999. Social instability and redistribution of income. European Journal of Political Economy 15, 35-51.

[38] Fearon, J., 2003. Ethnic and cultural diversity by country. Journal of Economic Growth 8, 1995-2222.

[39] Flora, P., with Alber, J., Eichenberg, R., Kohl, J., Kraus, F., Pfenning, W., Seebohm, K., 1983. State, Economy and Society 1815-1975, Vol. I. Campus Verlag, Frankfurt, Germany.

[40] Franck, R., 2014. The political consequences of income shocks: explaining the consolidation of democracy in France. Mimeo, Bar Ilan University.

[41] Gassebner, M., Lamla, M.J., Vreeland, J.R., 2013. Extreme bounds of democracy. Journal of Conflict Resolution 57, 171-197.

[42] Gleditsch, K.S., Ward, M.D., 2006. Diffusion and the international context of democratization. International Organization 60, 911-933.

[43] Gundlach, E., Paldam, M., 2009. A farewell to critical junctures: sorting out long-run causality of income and democracy. European Journal of Political Economy 25, 340-354.

[44] Hall, R.E., Jones, C.I., 1999. Why do some countries produce so much more output per worker than others. Quarterly Journal of Economics 114, 83-116.

[45] Halevy, E., 1935. English public opinion and the French Revolution of the nineteenth century. In: Coville, A., Temperley, H. (eds.), Studies in AngloFrench History During the Eighteenth, Nineteenth and Twentieth Centuries, Cambridge University Press, Cambridge, UK.

[46] Jack, W., Lagunoff, R., 2006. Dynamic enfranchisement. Journal of Public Economics 90, 551-572

[47] Jacks, D.S., 2005. Intra- and international commodity market integration in the Atlantic economy, 1800-1913. Explorations in Economic History 42, 381-413.

[48] Janowitz, M., 1976. Military institutions and citizenship in western societies. Armed Forces and Society 2, 185-203.

[49] Judson, R.A., Owen, A.L., 1999. Estimating dynamic panel data models: a practical guide for macroeconomists. Economic Letters 65, 9-15.

[50] Justman, M., Gradstein, M., 1999. The industrial revolution, political transition, and the subsequent decline in inequality in 19th-century Britain. Explorations in Economic History 36, 109-127.

[51] Kim, W., 2007. Social insurance expansion and political regime dynamics in Europe, 1880-1945. Social Science Quarterly 88, 494-514.

[52] King, G., Zeng, L., 2001. Logistic regression in rare events data. Political Analysis 9, 137-163.

[53] Kuran, T., 1989. Sparks and prairie fires: a theory of unanticipated political revolution. Public Choice 61, 41-74.

[54] Lipset, S.M., 1960. Political Man: The Social Basis of Modern Politics. Doubleday, New York. 
[55] Lizzeri, A., Persico, N., 2004. Why did the elites extend the suffrage? Democracy and the scope of government, with an application to Britain's 'Age of Reform'. Quarterly Journal of Economics 119, 707-765.

[56] Llavador, H., Oxoby, R.J., 2005. Partisan competition, growth, and the franchise. Quarterly Journal of Economics 120, 1155-1192.

[57] Lopez-Cordova, J.E., Meissner, C.M., 2008. The globalization of trade and democracy, 1870-2000. World Politics 60, 539-575.

[58] Manski, C.F., 1993. Identification of endogenous social effects: the reflection problem. Review of Economic Studies 60, 531-542.

[59] Miguel, E., Satyanath, S., Sergent, E., 2004. Economic shocks and civil conflict: an instrumental variables approach. Journal of Political Economy, 112, 725-753.

[60] Papke, L.E., J.M. Wooldridge, 1996. Econometric methods for fractional response variables with an application to $401(\mathrm{k})$ plan participation rates. Journal of Applied Econometrics 11, 619-632.

[61] Persson, T., Tabellini, G., 2009. Democratic capital: the nexus of political and economic change. American Economic Journal: Macroeconomics 1, 88-126.

[62] Potrafke, N., Vaubel, R., 2011. The interjurisdictional migration of European authors of liberty, 1660-1961: a quantitative analysis. Mimeo, University of Konstanz.

[63] Przeworski, A., Limongi, F., 1997. Modernization: theories and facts. World Politics 49, 155-183.

[64] Przeworski, A., Alvarez, M.E., Cheibub, J.A., Limongi, F., 2000. Democracy and Development: Political Institutions and Well-being in the World, 19501990. Cambridge University Press, Cambridge, UK.

[65] Przeworski, A., 2009. Conquered or granted? A history of suffrage extensions. British Journal of Political Science 39, 291-321.

[66] Sambanis, N., Hegre, H., 2006. Sensitivity analysis of empirical results on civil war onset. Journal of Conflict Resolution 50, 508-535.

[67] Seymour, C., Frary, D.P., 1918. How the World Votes: The Story of Democratic Development in Elections. C. A. Nichols, Springfield, MA.

[68] Stuurman, S., 1991. 1848: Revolutionary reforms in the Netherlands. European History Quarterly 21, 445-480.

[69] Ticchi, D., Vindigni, A., 2009. War and endogenous democracy. Mimeo, University of Princeton.

[70] Tilly, C., 1993. European Revolutions: 1492-1992. Wiley-Blackwell, Oxford, UK.

[71] Tilly, C., 1995. Popular Contention in Great Britain, 1758-1834. Harvard University Press, Cambridge, MA.

[72] Tilly, C., 2004. Contention and Democracy in Europe, 1650-2000. Cambridge University Press, Cambridge, UK.

[73] Todd, A., 1998. Revolutions, 1789-1917. Cambridge University Press, Cambridge, UK. 
[74] Tullock, G., 1971. The paradox of revolution. Public Choice 11, 89-99.

[75] Weyland, K., 2010. The diffusion of regime contention in European democratization, 1830-1940. Comparative Political Studies 43, 1148-1176. 
Table 1: Timing of Suffrage Reforms and Revolutionary Events in Europe, 1820-1938.

\begin{tabular}{|c|c|c|c|}
\hline Country $^{\mathbf{a}}$ & $\begin{array}{l}\text { Franchise } \\
\text { extensions }\end{array}$ & $\begin{array}{c}\text { Revolutionary } \\
\text { events }\end{array}$ & $\begin{array}{c}\text { Franchise } \\
\text { contractions }\end{array}$ \\
\hline \multicolumn{4}{|l|}{ Panel A } \\
\hline United Kingdom (1820) & $\begin{array}{l}\text { 1832, 1867, 1884, } \\
1918\end{array}$ & & None \\
\hline Austria $(1867,1934)$ & 1867, 1896, 1907 & 1848-49 & 1934 \\
\hline Italy $(1861,1924)$ & $\begin{array}{l}\text { 1861, 1882, 1912, } \\
1919\end{array}$ & $1820,1848-49$ & 1924 \\
\hline Norway (1820) & (1814), 1884, 1897, 1919 & & None \\
\hline The Netherlands (1830) & $\begin{array}{l}\text { (1815), 1848, 1887, 1894, } \\
1917\end{array}$ & & None \\
\hline Sweden (1820) & $1866,1907,1919$ & & None \\
\hline France (1820) & $1820,1830, \mathbf{1 8 4 8},(1870)$ & $\begin{array}{l}\text { 1830, 1848, } \\
1870-71\end{array}$ & $1852-1869$ \\
\hline Germany $(1871,1933)$ & 1871,1919 & 1848-49 & 1933 \\
\hline Finland (1820) & 1869, 1906 & & None \\
\hline Belgium (1830) & 1831, 1848, 1893, 1919 & $1830-33$ & None \\
\hline Switzerland (1848) & 1848 & & None \\
\hline Denmark (1820) & 1849, 1915 & & $\begin{array}{l}1866 \\
1875-1901\end{array}$ \\
\hline \multicolumn{4}{|l|}{ Panel B } \\
\hline Luxembourg (1820) & $\begin{array}{l}\text { 1841, 1848, 1857, 1893, } \\
\text { 1902, 1919 }\end{array}$ & & 1860 \\
\hline Iceland (1874) & 1874, 1908, 1916, 1934 & & None \\
\hline Spain $(1820,1936)$ & $\begin{array}{l}\text { (1812), 1820, 1834, 1837, } \\
\text { 1865, 1869, 1888, 1890, } \\
\mathbf{1 9 3 1}\end{array}$ & $\begin{array}{l}\mathbf{1 8 2 0}-23,1827,1836, \\
\text { 1840, 1842, 1854-56, } \\
\text { 1866, 1868, 1873-74, 1890, } \\
\text { 1909, 1933, } 1934\end{array}$ & $\begin{array}{l}1823-33,1845 \\
1876,1923 \\
1936,1938\end{array}$ \\
\hline Portugal $(1820,1926)$ & $\begin{array}{l}\text { 1822, 1838, 1852, 1878, } \\
1911\end{array}$ & $\begin{array}{l}\text { 1820, 1910, 1915, 1919, } \\
1927\end{array}$ & 1826, 1895, 1926 \\
\hline Serbia (1820) & $1868, \mathbf{1 8 8 8}, 1903,1920$ & 1861 & $\begin{array}{l}\text { 1893, 1894, 1901, } \\
1931\end{array}$ \\
\hline Greece (1822) & 1822,1844 & $\begin{array}{l}\text { 1843, 1866-68, 1935, } \\
1938\end{array}$ & None \\
\hline Romania $(1856,1938)$ & 1866, 1923 & & 1938 \\
\hline Poland (1918) & 1921 & 1830-31, 1863-64 & 1926,1935 \\
\hline Hungary $(1867,1936)$ & 1867 & 1848-49, 1918-19 & 1920,1936 \\
\hline Russia $(1820,1917)$ & 1906 & 1905,1917 & 1907,1917 \\
\hline \multicolumn{4}{|l|}{ Panel C } \\
\hline Ireland (never) & & 1916 & \\
\hline $\begin{array}{l}\text { Other part of Balkans } \\
\text { (never) }\end{array}$ & & 1826, 1885, 1888, 1907 & \\
\hline
\end{tabular}

Notes: See Data Appendix A and B for information on the coding. The franchise extensions in boldface are those which were followed by a franchise contraction within 10 years. The revolutionary events in boldface are those which we characterize as major events. a. The first year in brackets indicates the year in which the country enters our samples and the second year, if applicable, is the year in which the country regresses into autocracy or civil war. The 12 countries listed in panel A are included in the Western European Sample. The Broader European Sample includes, in addition, the 10 countries listed in panel B. The countries listed in panel C are not in the sample, but we make use of revolutionary events that happened in Ireland and on the Balkans in the construction of the measure of the threat of revolution. 
Table 2: Baseline Results for the Panel Model.

Dependent variable: Suffrage.
(1)
(2)

(3)

(4)

(5)

(6)

$\mathrm{TR}^{\mathrm{u}}$ (unweighted)

$1.89 * * *$

[5.88]

$\mathrm{TR}^{\mathrm{g}}$ (geographical)

$\mathrm{TR}^{\mathrm{l}}$ (linguistic)

[6.75]

Suffrage lagged

Log GDP per capita

$\begin{array}{ll}0.94 * * * & 0.94 * * \\ {[71.04]} & {[72.76]}\end{array}$

Log population

Urbanization rate

War

WWI

Educational attainment

Gold standard

Observations

Number of countries

Estimation technique

Selection-ratio

\subsection{6***}

[5.73]

$1.19 * * *$

[6.44]

$3.13^{* *}$

[2.14]

$0.94 * *$

[70.28]

$0.93 * * *$

[69.00]

0.12

[0.05]

3.92*

[1.78]

0.003

[0.38]

$4.21^{* * *}$

[3.97]

$-2.00$

[-1.05]

$-0.81$

[-0.93]

0.24

[0.31]

1069

1069

12

OLS
12

OLS

3.7

OLS

3.7

$$
\text { [6.44] }
$$

$0.93 * * *$

$0.93 * * *$

[70.66]

[68.25]

0.34

[-0.08]

[0.13]

3.98*

$3.77 *$

[1.84]

[1.69]

0.003

0.003

[0.35]

$4.08 * * *$

$4.32 * * *$

[3.87]

[4.08]

$-1.98$

$-2.00$

[-1.07]

[-1.08]

$-0.8$

$-0.84$

[-0.93]

0.2

[-0.97]

[0.26]

0.26

[0.34]

1069

1069

12

12

OLS

OLS

Notes: $\mathrm{z}$ statistics in square brackets are based on PCSE standard errors allowing for panel heteroskedasticity and contemporaneously correlated across panel units, and for a country specific AR(1) process over time (clustering by country); * significant at 10\%; ** significant at 5\%; *** significant at 1\%. All estimations include country and two-year time fixed effects. We estimate with the xtpcse command in STATA 13 (Beck and Katz, 1995). It estimates the parameters by OLS and calculates PCSE corrected standard errors. The selection-ratio (Altonji et al., 2005) indicates how many times stronger selection on unobserved factors needs to be relative to selection on the observable factors included in the three specifications for the point estimate on the threat of revolution variables to be attributable entirely to omitted variables bias. 
Table 3: Results for the Panel Model: Conley spatial dependence, the reflection problem, reverse causality and own revolutions.

\begin{tabular}{|c|c|c|c|c|c|c|c|}
\hline \multirow[t]{2}{*}{ Dependent variable: } & \multicolumn{6}{|c|}{ Suffrage } & \multirow{2}{*}{$\frac{\Delta \text { Suffrage }}{(7)}$} \\
\hline & (1) & (2) & (3) & $(4)$ & (5) & (6) & \\
\hline $\mathrm{TR}^{\mathrm{g}}$ & $\begin{array}{l}1.19 * * \\
(2.09)\end{array}$ & $\begin{array}{l}1.19 * * \\
(2.54)\end{array}$ & $\begin{array}{c}1.19 * * * \\
(3.48)\end{array}$ & $\begin{array}{c}1.21 * * * \\
{[6.19]}\end{array}$ & & $\begin{array}{c}1.18 * * * \\
{[6.37]}\end{array}$ & \\
\hline $\mathrm{TR}^{\mathrm{g}}$ (lagged) & & & & & $\begin{array}{l}1.02 * * \\
{[2.55]}\end{array}$ & & $\begin{array}{c}1.26 * * * \\
{[3.04]}\end{array}$ \\
\hline Suffrage reforms abroad & & & & $\begin{array}{c}-1.01 \\
{[-0.35]}\end{array}$ & & & \\
\hline Own revolution & & & & & & $\begin{array}{c}9.12 * * * \\
{[4.00]}\end{array}$ & \\
\hline Observations & 1069 & 1069 & 1069 & 1069 & 1069 & 1069 & 1069 \\
\hline Number of countries & 12 & 12 & 12 & 12 & 12 & 12 & 12 \\
\hline Estimation technique & OLS & OLS & OLS & OLS & OLS & OLS & OLS \\
\hline Spatial correction & $500 \mathrm{~km}$ & $800 \mathrm{~km}$ & $1400 \mathrm{~km}$ & PCSE & PCSE & PCSE & PCSE \\
\hline
\end{tabular}

Notes: $\mathrm{z}$ statistics in brackets are based on spatial (Conley, 1999) standard errors for three different radiuses; z statistics in square brackets are based on PCSE standard errors allowing for panel heteroskedasticity and contemporaneously correlated across panel units, and for a panel specific AR(1) process over time (clustering by country); * significant at $10 \%$; ** significant at 5\%; *** significant at $1 \%$. All estimations include country and two-year time fixed effects and the same set of control variables as in Table 2, column five. The results in columns one to three are obtained with the OLS estimator and the standard errors proposed by Conley (1999) which allow for contemporaneous spatial dependence amongst the disturbances. The metric used to measure distance between panel units is distance in kilometres between pairs of capital cities. The three specifications differ in the assumed cut-off after which the spatial dependence is zero. The results in columns four and five are obtained with the same estimation technique as in Table 2.

Table 4: Within year Timing of Revolutionary Events and Suffrage Reforms

\begin{tabular}{|c|c|c|}
\hline Year & Onset of revolutionary event & Announcement of concession \\
\hline 1820 & $\begin{array}{l}\text { Spain: January } \\
\text { Portugal: January } \\
\text { Italy: July }\end{array}$ & France: November \\
\hline 1830 & $\begin{array}{l}\text { France: July. } \\
\text { Belgium: August } 25\end{array}$ & $\begin{array}{l}\text { France: July } \\
\text { United Kingdom: November } \\
\text { Belgium: December } 20\end{array}$ \\
\hline 1848 & $\begin{array}{l}\text { Southern Italy: January } \\
\text { France: February } 22 \\
\text { Germany: March } 3 \\
\text { Austria: March } 12 \\
\text { Northern Italy: March } 22 \\
\text { Hungary: May }\end{array}$ & $\begin{array}{l}\text { Switzerland: January } 27 \\
\text { France: February } 24 \\
\text { Luxemburg: March } 20 \\
\text { Denmark (1849): March } 18 \\
\text { Netherlands: March } 27 \\
\text { Belgium: March } 29\end{array}$ \\
\hline 1871 & France: May & Germany (1871): 1867 \\
\hline 1905 & Russia: January 9 & $\begin{array}{l}\text { Finland (1906): November } 12 \\
\text { Russia: February } 18\end{array}$ \\
\hline 1915 & Portugal: May 10 & Denmark: May 7 \\
\hline 1916 & Ireland: Easter & \\
\hline 1917 & Russia: February & $\begin{array}{l}\text { United Kingdom (1918): } 1912 \\
\text { The Netherlands: Summer. }\end{array}$ \\
\hline 1918 & Hungary: November & $\begin{array}{l}\text { Germany (1919): November. } \\
\text { Sweden (1919): December }\end{array}$ \\
\hline 1919 & & $\begin{array}{l}\text { Italy: } 1919 . \\
\text { Norway: June. } \\
\text { Belgium: } 1919 .\end{array}$ \\
\hline
\end{tabular}

Notes: For each of the major revolutionary events, and for each suffrage reform that happened in the same calendar year, we have recorded the date of the onset of the revolutionary event and the date of the announcement of the reform or the date at which the process that led to the suffrage reform started. In column three, we record in bracket the year in which the reform was finally adopted, if this is different from the year in which the reform was announced.

Source: The information used to record these dates is given in the Data Appendix. 
Table 5: Results for the Panel Model: One-year time fixed effects.

\begin{tabular}{|c|c|c|c|c|c|c|}
\hline \multirow[t]{2}{*}{ Dependent variable: } & \multicolumn{2}{|c|}{ Suffrage } & \multirow{2}{*}{$\frac{\Delta \text { Suffrage }}{(3)}$} & \multicolumn{2}{|c|}{ Suffrage } & \multirow{2}{*}{$\frac{\Delta \text { Suffrag }}{(6)}$} \\
\hline & (1) & (2) & & (4) & (5) & \\
\hline $\mathrm{TR}^{\mathrm{g}}$ & $\begin{array}{c}1.18^{* * *} \\
{[6.35]}\end{array}$ & & & $\begin{array}{c}1.03^{*} \\
\{1.85\} \\
(1.81)\end{array}$ & & \\
\hline TR (lagged) & & $\begin{array}{c}1.15^{* * *} \\
{[2.88]}\end{array}$ & $\begin{array}{c}1.41^{* * *} \\
{[3.42]}\end{array}$ & & $\begin{array}{l}1.10 * * \\
\{2.14\} \\
(2.46)\end{array}$ & $\begin{array}{c}1.37 * * * \\
\{2.67\} \\
(2.62)\end{array}$ \\
\hline Observations & 1069 & 1069 & 1069 & 1069 & 1069 & 1069 \\
\hline Number of countries & 12 & 12 & 12 & 12 & 12 & 12 \\
\hline One-year fixed effects & NO & $\mathrm{NO}$ & NO & YES & YES & YES \\
\hline Two-year fixed effects & YES & YES & YES & NO & NO & NO \\
\hline Estimation technique & OLS & OLS & OLS & OLS & OLS & OLS \\
\hline Spatial correlation & PCSE & PCSE & PCSE & Conley & Conley & Conley \\
\hline
\end{tabular}

Notes: $\mathrm{z}$ statistics in square brackets are based on PCSE standard errors allowing for panel heteroskedasticity and contemporaneously correlated across panel units, and for a panel specific AR(1) process over time (clustering by country); $z$ statistics in curly brackets are PCSE standard errors without spatial correlation, but with panel heteroskedasticity adjustment and clustering by country; z statistics in brackets are based on spatial (Conley, 1999) standard errors (1400km); * significant at 10\%; ** significant at $5 \%$; *** significant at $1 \%$. The estimations in columns one to three include country and two-year time fixed effects and the same set of control variables as in Table 3, column six, except that we exclude the dummy for WWI to make these estimations comparable to those reported in columns four to six. The estimations in four to six include country and one-year time fixed effects and the same set of control variables as in Table 3, column six, except that the dummy for WWI drops out because it is perfectly collinear with the one-year time fixed effects. 
Table 6: Results for the Panel Model: Repression, Transfers, Economics Shocks and Other Robustness Checks.

Dependent variable: Suffrage.

\begin{tabular}{|c|c|c|c|c|c|c|c|c|}
\hline & (1) & (2) & $(3)^{b}$ & $(4)^{\mathrm{b}, \mathrm{c}}$ & $(5)^{\mathrm{b}, \mathrm{c}}$ & (6) & $(7)^{c}$ & $(8)^{d}$ \\
\hline $\mathrm{TR}^{\mathrm{g}}$ & $\begin{array}{c}1.91 * * * \\
{[4.49]}\end{array}$ & $\begin{array}{c}1.37 * * * \\
{[6.76]}\end{array}$ & $\begin{array}{c}1.21^{* * *} \\
{[6.53]}\end{array}$ & $\begin{array}{c}1.18^{* * *} \\
{[6.00]}\end{array}$ & $\begin{array}{c}1.17^{* * * *} \\
{[5.87]}\end{array}$ & & $\begin{array}{c}1.19 * * * \\
{[6.01]}\end{array}$ & $\begin{array}{c}1.18^{* * * *} \\
{[5.55]}\end{array}$ \\
\hline $\mathrm{TR}^{\mathrm{g}}$ (all) & & & & & & $\begin{array}{c}0.84^{* * *} \\
{[4.89]}\end{array}$ & & \\
\hline Repression & & $\begin{array}{c}-0.02 \\
{[-0.45]}\end{array}$ & & & & & & \\
\hline Fiscal transfers & $\begin{array}{c}-0.05 \\
{[-1.22]}\end{array}$ & & & & & & & \\
\hline Trend & & & $\begin{array}{c}0.29 \\
{[0.10]}\end{array}$ & & & & & \\
\hline Cycle & & & $\begin{array}{c}3.48 \\
{[0.54]}\end{array}$ & & & & & \\
\hline Log Rainfall & & & & $\begin{array}{c}2.70 \\
{[1.17]}\end{array}$ & & & & \\
\hline Log Rainfall, lag & & & & $\begin{array}{c}0.52 \\
{[2.22]}\end{array}$ & & & & \\
\hline Rainfall growth & & & & & $\begin{array}{c}1.65 \\
{[0.92]}\end{array}$ & & & \\
\hline Rainfall growth, lag & & & & & $\begin{array}{c}1.01 \\
{[0.59]}\end{array}$ & & & \\
\hline Observations & 618 & 875 & 1045 & 809 & 809 & 1069 & 809 & 1089 \\
\hline No. of countries & $9^{\mathrm{a}}$ & $9^{\mathrm{a}}$ & 12 & 12 & 12 & 12 & 12 & 12 \\
\hline Robustness check & $\begin{array}{l}\text { Repres- } \\
\text { sion }\end{array}$ & $\begin{array}{l}\text { Fiscal } \\
\text { transfers }\end{array}$ & $\begin{array}{l}\text { Cycle } \\
\text { GDP }\end{array}$ & $\begin{array}{l}\text { Cycle } \\
\text { Rain } \\
\text { shocks }\end{array}$ & $\begin{array}{l}\text { Cycle } \\
\text { Rain } \\
\text { shocks }\end{array}$ & $\begin{array}{l}\text { All } \\
\text { events }\end{array}$ & $\begin{array}{l}\text { Till } \\
1913 \\
\text { only }\end{array}$ & $\begin{array}{l}\text { Demo- } \\
\text { cratic } \\
\text { reversals }\end{array}$ \\
\hline
\end{tabular}

Notes: $\mathrm{z}$ statistics in square brackets are based on PCSE standard errors allowing for panel heteroskedasticity and contemporaneously correlated across panel units, and for a panel specific AR(1) process over time (clustering by country); * significant at $10 \%$; ** significant at $5 \%$; *** significant at $1 \%$. All estimations use the same estimation technique and include country and two-year time fixed effects and the same set of control variables as in Table 2, column five. a. Data from Austria, Germany and Switzerland are missing. b. Log GDP per capita is replaced by cycle and trend or by the rainfall variables as appropriate. c. Till 1913. d. Reversals are included. 
Table 7: Results for the Panel Model: Alternative Estimation Methods.

Dependent variable: Suffrage.

\begin{tabular}{lccccccc}
\hline & $\mathbf{( 1 )}$ & $\mathbf{( 2 )}$ & $\mathbf{( 3 )}$ & $\mathbf{( 4 )}$ & $\mathbf{( 5 )}$ & $\mathbf{( 6 )}$ & $\mathbf{( 7 )}$ \\
\hline $\mathrm{TR}^{\mathrm{g}}$ & $1.19^{* * *}$ & $1.19^{* * *}$ & $1.19^{* * *}$ & $1.20^{* * *}$ & $1.32^{* * *}$ & $1.38^{* * *}$ & $0.11^{* *}$ \\
& {$[4.91]$} & {$[6.38]$} & {$[5.04]$} & {$[4.01]$} & {$[4.70]$} & {$[4.59]$} & {$[2.05]$} \\
Observations & 1069 & 1069 & 1069 & 1069 & 1069 & 1069 & 1061 \\
Number of countries & 12 & 12 & 12 & 12 & 12 & 12 & 12 \\
Estimation technique & OLS & OLS & OLS & Bruno & GMM & Tobit & Fractional \\
Spatial correlation & No & Unrestricted & No & No & No & No & No \\
Clustering & No & No & Country & No & No & No & Yes \\
\hline
\end{tabular}

Notes: $z$ statistics in square brackets; * significant at $10 \%$; ** significant at $5 \%$; *** significant at $1 \%$. All estimations include country and two-year time fixed effects and the same set of control variables as in Table 2, column five. The standard errors in columns one to three are adjusted for panel heteroskedasticity. The estimator used in column four is the bias-corrected least squares estimator proposed by Bruno (2005). The results in column five are obtained with the system-GMM estimator proposed by Blundell and Bond (1998). The marginal effect conditional on suffrage being strictly between 0 and 100 is the same as the coefficient estimate reported in column six. The fractional estimator used in column seven is due to Papke and Wooldridge (1996) and it transforms suffrage with a logit link. The coefficient is not comparable to the others, but $\exp (0.11)$ can be interpreted as an odds ratio. 
Table 8: Results from the Event History Study, Western European Sample.

Dependent variable: reform.

\section{(1)}

(2)

(3)

(4)

(5)

(6)

$(7)^{\mathrm{a}}$

(8)

\begin{tabular}{|c|c|c|c|c|c|c|c|c|}
\hline $\mathrm{TR}^{\mathrm{u}}$ (unweighted) & $\begin{array}{c}0.75^{* * *} \\
{[5.25]}\end{array}$ & & & & & & & \\
\hline $\mathrm{TR}^{\mathrm{g}}$ (geographical) & & $\begin{array}{c}0.50 * * * \\
{[7.57]}\end{array}$ & & & $\begin{array}{c}0.40 * * * \\
{[4.84]}\end{array}$ & $\begin{array}{c}0.48^{* * *} \\
{[7.34]}\end{array}$ & $\begin{array}{c}0.39 * * * \\
{[9.75]}\end{array}$ & $\begin{array}{c}0.73 * * * \\
{[4.30]}\end{array}$ \\
\hline TR $^{1}$ (linguistic) & & & $\begin{array}{c}3.93 * * * \\
{[5.38]}\end{array}$ & & & & & \\
\hline $\mathrm{TR}^{\mathrm{g}}$ (lagged) & & & & $\begin{array}{c}0.40 * * * \\
{[4.61]}\end{array}$ & & & & \\
\hline Suffrage reforms abroad & & & & & $\begin{array}{c}5.44 * * * \\
{[3.09]}\end{array}$ & & & \\
\hline Log GDP per capita & $\begin{array}{l}2.45^{* *} \\
{[2.44]}\end{array}$ & $\begin{array}{l}2.29 * * \\
{[2.23]}\end{array}$ & $\begin{array}{c}1.66^{* * *} \\
{[2.59]}\end{array}$ & $\begin{array}{l}2.13 * * \\
{[2.18]}\end{array}$ & $\begin{array}{l}2.06^{* *} \\
{[2.17]}\end{array}$ & $\begin{array}{l}2.11^{* *} \\
{[2.09]}\end{array}$ & $\begin{array}{c}1.36 \\
{[1.44]}\end{array}$ & $\begin{array}{c}2.37 \\
{[0.82]}\end{array}$ \\
\hline Log population & $\begin{array}{l}0.47^{*} \\
{[1.75]}\end{array}$ & $\begin{array}{l}0.49 * \\
{[1.80]}\end{array}$ & $\begin{array}{c}0.32 \\
{[1.03]}\end{array}$ & $\begin{array}{l}0.47^{*} \\
{[1.72]}\end{array}$ & $\begin{array}{l}0.43^{*} \\
{[1.69]}\end{array}$ & $\begin{array}{l}0.45^{*} \\
{[1.68]}\end{array}$ & $\begin{array}{c}0.20 \\
{[1.05]}\end{array}$ & $\begin{array}{c}5.47 \\
{[1.26]}\end{array}$ \\
\hline Urbanization rate & $\begin{array}{l}-0.003 \\
{[-1.53]}\end{array}$ & $\begin{array}{l}-0.003 \\
{[-1.55]}\end{array}$ & $\begin{array}{l}-0.002 \\
{[-0.85]}\end{array}$ & $\begin{array}{l}-0.003 \\
{[-1.29]}\end{array}$ & $\begin{array}{l}-0.003 \\
{[-1.34]}\end{array}$ & $\begin{array}{l}-0.003 \\
{[-1.37]}\end{array}$ & $\begin{array}{c}-0.0009 \\
{[-0.39]}\end{array}$ & $\begin{array}{l}-0.003 \\
{[-0.32]}\end{array}$ \\
\hline War & $\begin{array}{c}-0.15 \\
{[-0.20]}\end{array}$ & $\begin{array}{c}-0.29 \\
{[-0.47]}\end{array}$ & $\begin{array}{c}0.18 \\
{[0.12]}\end{array}$ & $\begin{array}{c}0.101 \\
{[0.10]}\end{array}$ & $\begin{array}{c}-0.10 \\
{[-0.16]}\end{array}$ & $\begin{array}{c}-0.21 \\
{[-0.35]}\end{array}$ & $\begin{array}{c}-0.04 \\
{[-0.06]}\end{array}$ & $\begin{array}{c}-0.88 \\
{[-0.15]}\end{array}$ \\
\hline WWI & $\begin{array}{c}-1.52 \\
{[-1.15]}\end{array}$ & $\begin{array}{c}-1.17 \\
{[-0.93]}\end{array}$ & $\begin{array}{c}-2.14 \\
{[-1.24]}\end{array}$ & $\begin{array}{c}-1.36 \\
{[-0.95]}\end{array}$ & $\begin{array}{c}-0.92 \\
{[-0.74]}\end{array}$ & $\begin{array}{c}-0.96 \\
{[-0.78]}\end{array}$ & $\begin{array}{c}-0.89 \\
{[-0.71]}\end{array}$ & $\begin{array}{c}-2.40 * * \\
{[-1.96]}\end{array}$ \\
\hline Educational attainment & $\begin{array}{c}-0.06 \\
{[-0.09]}\end{array}$ & $\begin{array}{c}0.005 \\
{[0.007]}\end{array}$ & $\begin{array}{c}-0.24 \\
{[-0.40]}\end{array}$ & $\begin{array}{c}-0.03 \\
{[-0.05]}\end{array}$ & $\begin{array}{c}0.06 \\
{[0.08]}\end{array}$ & $\begin{array}{c}0.01 \\
{[0.02]}\end{array}$ & $\begin{array}{c}0.42 \\
{[0.68]}\end{array}$ & $\begin{array}{c}0.042 \\
{[0.05]}\end{array}$ \\
\hline Gold standard & $\begin{array}{l}-1.12 * \\
{[-1.93]}\end{array}$ & $\begin{array}{l}-0.95^{*} \\
{[-1.68]}\end{array}$ & $\begin{array}{c}-0.70 \\
{[-1.47]}\end{array}$ & $\begin{array}{c}-1.15^{* *} \\
{[2.16]}\end{array}$ & $\begin{array}{c}-0.83 \\
{[-1.51]}\end{array}$ & $\begin{array}{c}-0.87 \\
{[-1.56]}\end{array}$ & $\begin{array}{c}-0.72 \\
{[-1.22]}\end{array}$ & $\begin{array}{c}-1.21 * * \\
{[-2.05]}\end{array}$ \\
\hline Observations & 713 & 713 & 713 & 713 & 713 & 713 & $739^{\mathrm{b}}$ & 713 \\
\hline Number of countries & 11 & 11 & 11 & 11 & 11 & 11 & 11 & 11 \\
\hline Estimation technique & $\begin{array}{c}\text { Logit } \\
\text { clustered } \\
\text { by } \\
\text { country }\end{array}$ & $\begin{array}{c}\text { Logit } \\
\text { clustered } \\
\text { by } \\
\text { country }\end{array}$ & $\begin{array}{c}\text { Logit } \\
\text { clustered } \\
\text { by } \\
\text { country }\end{array}$ & $\begin{array}{c}\text { Logit } \\
\text { clustered } \\
\text { by } \\
\text { country }\end{array}$ & $\begin{array}{c}\text { Logit } \\
\text { clustered } \\
\text { by } \\
\text { country }\end{array}$ & $\begin{array}{c}\text { Rare } \\
\text { events } \\
\text { logit }\end{array}$ & $\begin{array}{c}\text { Logit } \\
\text { clustered } \\
\text { by } \\
\text { country }\end{array}$ & $\begin{array}{l}\text { Cond. } \\
\text { fixed } \\
\text { effects } \\
\text { logit }\end{array}$ \\
\hline
\end{tabular}

Notes: $z$ statistics based on clustered (by country) standard errors in square brackets, except in column five; * significant at $10 \%$; ** significant at 5\%; *** significant at $1 \%$. Constant term not reported. Only 11 countries are included in the event history study, as Switzerland had full male suffrage from the time it became unified. The dependent variable reform is coded as 1 if country i introduced a franchise extension in year $t$ and as 0 in the years before and after that. A country drops out of the sample in the year after universal male suffrage was reached or if it, before that happened, regressed into dictatorship. A country enters the "risk set" either in 1820 or at the time of independence (as recorded in column one of Table 1). We follow Beck et al. (1998) and use a discrete logistic specification (logit) to estimate the conditional probability of a reform in a given year. In column five, we adopt the rare events logit estimator by King and Zeng (2001) and in column seven we include fixed effects directly in the logic model. All estimations allow for duration dependence of the hazard rate. A likelihood ratio test indicates strong duration dependence in the baseline hazard rate. a. Reform is coded to exclude franchise extensions that were followed by a franchise contraction within a 10 years window. b. The extra observations are due to the fact that France stays in the sample till 1870 and Italy stays till 1924. 
Table 9: Results from the Event History Study, Broader European Sample.

Dependent variable: reform.

\begin{tabular}{lcccccccc}
\hline & $\mathbf{( 1 )}$ & $\mathbf{( 2 )}$ & $\mathbf{( 3 )}$ & $\mathbf{( 4 ) ^ { \mathbf { e } }}$ & $\mathbf{( 5 )}$ & $\mathbf{( 6 )}$ & $\mathbf{( 7 )}$ & $\mathbf{( 8 )}^{\mathbf{e}}$ \\
\hline $\mathrm{TR}^{g}$ & $0.31^{* * *}$ & $0.31^{* * *}$ & $0.31^{* * *}$ & $0.28^{* * *}$ & $0.34^{* * *}$ & $0.34^{* * *}$ & $0.40^{* * *}$ & $0.28^{* * *}$ \\
& {$[4.78]$} & {$[4.79]$} & {$[5.11]$} & {$[4.40]$} & {$[4.15]$} & {$[4.17]$} & {$[3.97]$} & {$[3.69]$} \\
Log GDP per capita & & & & & 0.14 & 0.16 & 0.707 & 0.60 \\
& & & & & {$[0.29]$} & {$[0.33]$} & {$[0.38]$} & {$[0.87]$} \\
Log population & & & & & $0.31^{* *}$ & $0.30 * *$ & 2.03 & -0.46 \\
& & & & & {$[2.47]$} & {$[2.45]$} & {$[0.81]$} & {$[1.37]$} \\
War & 0.15 & 0.23 & 0.29 & 0.25 & 0.48 & 0.53 & 0.579 & 0.34 \\
& {$[0.28]$} & {$[0.43]$} & {$[0.494]$} & {$[0.44]$} & {$[0.69]$} & {$[0.77]$} & {$[0.84]$} & {$[0.67]$} \\
WWI & 0.04 & 0.14 & -0.201 & 0.20 & -0.58 & -0.45 & -1.15 & 0.15 \\
& {$[0.06]$} & {$[0.21]$} & {$[-0.332]$} & {$[0.28]$} & {$[-0.66]$} & {$[-0.52]$} & {$[-1.45]$} & {$[1.37]$} \\
Observations & 1700 & 1700 & 1700 & $1726^{\mathrm{d}}$ & 1132 & 1132 & 1063 & $1158^{\mathrm{d}}$ \\
Number of countries & $21^{\mathrm{a}}$ & $21^{\mathrm{a}}$ & $21^{\mathrm{a}}$ & $21^{\mathrm{a}}$ & $17^{\mathrm{b}}$ & $17^{\mathrm{b}}$ & $15^{\mathrm{c}}$ & $17^{\mathrm{b}}$ \\
Estimation technique & Logit & Rare & Condi- & Logit & Logit & Rare & Condi- & Logit \\
& clustered & Events & tional & clustered & clustered & Events & tional & clustered \\
& by & logit & fixed & by & by & logit & fixed & by \\
& country & & effects & country & country & & effects & country \\
& & & Logit & & & & Logit &
\end{tabular}

Notes: $\mathrm{z}$ statistics based on clustered (by country) standard errors in square brackets, except in columns two and six; * significant at $10 \%$; $* *$ significant at $5 \%$; *** significant at $1 \%$. The definition of reform and the details of estimation techniques are in notes to Table 7 . All estimations allow for duration dependence of the hazard rate. A likelihood ratio test indicates strong duration dependence in the baseline hazard rate. a. The sample includes Austria, Belgium, Finland, Sweden, Norway, Denmark, the Netherlands, the United Kingdom, France, Germany, Italy, Spain, Hungary, Portugal, Greece, Iceland, Luxembourg, Serbia, Poland, Russia and Rumania. b. These specifications exclude Russia, Serbia, Iceland, and Luxembourg. c. This specification excludes Hungary and Poland as well as the countries listed under b. d. The extra observations are due to the fact that France stays in the sample till 1870 and Italy stays till 1924. e. The specification excludes franchise extensions that were reversed within ten years. 
Table 10: Additional Results for the Panel and Event History Models, Western European Sample

\begin{tabular}{|c|c|c|c|c|c|c|c|c|}
\hline & $(1)^{b}$ & $(2)^{b}$ & (3) & (4) & $(5)^{b}$ & $(6)^{b}$ & (7) & (8) \\
\hline Robustness check & $\begin{array}{c}\text { Add } \\
\text { trade } \\
\text { volumes }\end{array}$ & $\begin{array}{c}\text { Add } \\
\text { wheat } \\
\text { price } \\
\text { spread }\end{array}$ & $\begin{array}{c}\text { Add } \\
\text { agricultural } \\
\text { share }\end{array}$ & $\begin{array}{l}\text { Add war- } \\
\text { intensity }\end{array}$ & $\begin{array}{c}\text { Add } \\
\text { trade } \\
\text { volumes }\end{array}$ & $\begin{array}{c}\text { Add } \\
\text { wheat } \\
\text { price } \\
\text { spread }\end{array}$ & $\begin{array}{c}\text { Add } \\
\text { agricultural } \\
\text { share }\end{array}$ & $\begin{array}{l}\text { Add war- } \\
\text { intensity }\end{array}$ \\
\hline
\end{tabular}

Dependent variable

Suffrage

Reform

$\mathrm{TR}^{\mathrm{g}}$

$1.49 * * * \quad 1.51 * * * \quad 0.89 * * *$

$1.19 * * * \quad 0.52 * * * \quad 0.51 * *$

$0.41 * * *$

$0.49 * * *$

[7.19]

[3.97]

[3.74]

[6.47]

[6.44]

[2.28]

[4.31]

[6.58]

Trade volume

0.01

[1.63]

Wheat price spread

[1.44]

13.55**

[2.42]

Agricultural share

$-0.01$

0.001

[-1.41]

[0.20]

War intensity

$5.59 * *$

[2.26]

Observations

858

436

1069

585

355

12

$11^{\mathrm{a}}$

$7^{\mathrm{b}}$

OLS OLS

12

Estimation technique

with

OLS

OLS

Logit

with

with

PCSE

PCSE

PCSE

by

clustered

clustered

clustered

clustered

Logit

by

by

country country

by

country

Notes: See notes to Table 2 and Table 7. The independent variable in the estimations in columns one to four is suffrage. These estimations include country and two-year time fixed effects and the same set of control variables as in Table 2. We only report the coefficients on the new variables which are added to each specification. The models in columns five to eight are all logit models for the probability of a suffrage reform. These estimations include the same control variables as in Table 7 and allow for duration dependence. a. Data from Denmark, Finland, the Netherlands, Sweden, and Switzerland are missing; b. Gold standard is replaced by the alternative measure(s) of trade integration. 


\section{Supplementary Material}

Workers of the World, Unite! Franchise Extensions and the Threat of Revolution in Europe, 1820-1938

Supplementary material

\section{Theory Appendix: Proofs}

Deriving $\widehat{q}_{R E V O L T}$. At stage 3, which is reached only if the insiders neither extended the franchise nor invested in repression in stage 2 , the outsiders do not know the social state. Suppose they observe an uninformative report. In this case, $q_{1 t}=q$ (and is expected to be at this level in all future periods). If the outsiders do not revolt, then they get $y_{O}(\mathcal{A})+\beta V_{O}(\mathcal{A})$, where $V_{O}(\mathcal{A})$ is the outsiders' expected discounted utility when the political state is autocracy. If they decide to revolt, they face a lottery and their expected discounted utility is

$$
(1-q p)\left(y_{O}(\mathcal{A})-\mu+\beta V_{O}(\mathcal{A})\right)+q p\left(\frac{y_{O}(\mathcal{S})}{1-\beta}-\mu\right) .
$$

Suppose that $q$ is such that the outsiders never start a revolution. Then $V_{O}(\mathcal{A})=$ $\frac{y_{O}(A)}{1-\beta}$, and we can find the critical value of $q$ at which they are indifferent between revolting and not revolting after receiving $L_{1 t}=1$ as $\widehat{q}_{R E V O L T}$ defined in equation (1).

Deriving condition $[D], \widehat{q}_{D E M O C R A C Y}$ and $\widehat{q}_{R E P R E S S I O N}$. Democratization yields $\frac{y_{I}(\mathcal{D})}{1-\beta}$, while repression yields $y_{I}(\mathcal{A})-\sigma+\beta \frac{y_{I}(\mathcal{A})}{1-\beta}$ because the revolution is avoided for sure in this period and there is no expectation of a revolution in the future given Assumption 1. A simple comparison shows that franchise extension is better than repression if condition $[D]$ holds. The expected payoff of doing nothing after receiving the report $L_{1 t}=l$ is the lottery

$$
\frac{p q}{l} 0+\left(1-\frac{p q}{l}\right)\left(y_{I}(\mathcal{A})+\frac{\beta y_{I}(\mathcal{A})}{1-\beta}\right) .
$$

Accordingly, if condition $[D]$ holds (fails), we know that democratization (repression) is better than repression (democratization) and we can compare this expected payoff to $\frac{y_{I}(\mathcal{D})}{1-\beta}\left(y_{I}(\mathcal{A})-\sigma+\beta \frac{y_{I}(\mathcal{A})}{1-\beta}\right)$. This yields conditions $(3)$ and $(4)$ in the text, respectively. 


\section{Data Appendix A}

This appendix details the coding of suffrage reforms in Europe 1820-1938 and other aspects of the samples used in the study. The "Western European sample" includes Austria, Belgium, Finland, Sweden, Norway, Denmark, the Netherlands, Germany, the United Kingdom (excluding Ireland), France, Italy, and Switzerland. The "broader European sample" includes Spain, Portugal, Greece, Iceland, Luxembourg, Serbia, Hungary, Poland, Russia, and Romania in addition to those included in the "Western European sample".

A country enters the sample in 1820 or when it becomes an independent state. The entry year is recorded in the country tables ( $A 1$ to $A 22)$ below and in Table 1 in the text. In the cases, where it is not straightforward to determine the entry year, a justification for the choice is given. In the main specifications, a country drops out if it regresses into some form of autocracy or into civil war (e.g., Germany (1933), Austria (1934), Italy (1924), Spain (1936), Russia (1917)) before 1938. In some specifications, we keep countries in the sample after they regress to autocracy/dictatorship.

Tables $A 1$ to $A 22$ detail how we coded the years of "franchise extensions" and "franchise contractions". We have also, in some cases, recorded additional information about the evolution of democratic institutions in the sample and other relevant historical facts. This includes the year of women's suffrage, the introduction of the secret ballot or changes in the election rule, etc.

We use the following definitions to code the years of "franchise extensions" and "franchise contractions" as recorded in Table 1 in the main text and detailed below:

1) A "franchise extension" is a reform that relaxes socio-economic qualifications on the right to vote in elections to the lower chamber of parliament for men. This includes lowering of income, tax payment, and wealth qualifications; abolishment of education qualifications; enfranchisement of recipients of public support; and other such socio-economic qualifications, as well as the introduction of (qualified) voting rights in the first place.

Comment: We do not include women's suffrage or reforms that lowered the voting age, except if these happen in conjunction with changes in socio-economic 
qualifications, in the definition of a franchise extension. All the reforms recorded are de jure and varied in the de facto power they conferred on the newly enfranchised voters.

2) A "franchise contraction" is a) a reform that increases one or more of the socio-economic qualifications listed above and thus de jure (and de facto) disenfranchises voters who have previously enjoyed the right to vote or b) a discrete change in the rules that de facto restricts the right to vote which happens subsequent to a "franchise extension" as defined above and which do not coincide with that extension.

Comment: We want to record instances where voting rights which have been granted previously are subsequently taken back, either de jure or de facto. De facto franchise contractions require a discrete change and must happen subsequent to a franchise extension. Thus, this implies that we do not count the fact that the broad franchise in Imperial Germany introduced in 1871 was de facto restricted by the fact that electoral corruption was widespread, but we do count the de facto overturn of the Weimar Constitution by the Nazi regime in 1933. Likewise, we count the Second Empire from 1852 to 1869 in France, where elections were systematically manipulated, and the constitutional amendment in Denmark in 1866 as instances of franchise contraction.

In the tables below, we indicate in boldface the years that we count as years of franchise extension and indicate in italics the years that we count as years of franchise contraction.

The sources used to construct these data are: Flora et al. (1983), ${ }^{1}$ Carstairs (1980), Seymour and Frary (1918), Campbell (1958), Cook and Paxton (1998) and Caramani (2000). We have, in addition, made extensive use of Encyclopaedia Britannica (1911, 2009), Ortega and Blanco (1990), and Bataković (2007).

\section{[Appendix Table A1 to A22]}

\footnotetext{
${ }^{1}$ Notice that the dates given in chapter 3 of Flora et al. (1983) are the years of the first and last election under a given set of franchise rules, not the year in which the legislation was adopted.
} 


\section{Data Appendix B}

This appendix details the coding of revolutionary events in Europe 1820-1938. The coding is based on Tilly (1993, 2004) and is crosschecked with Todd (1998) and Hobsbawm (1962) and supplemented with information from Encyclopaedia Britannica $(1911,2009)$. Besides revolutionary events that took place in the countries included in the 'broader European sample', we also include events that took place in other countries in the Balkans and in Ireland.

Tilly defines revolutionary events as "those instances when for a month or more at least two blocks of people backed by armed forces and receiving support from a substantial part of the general population exercised control over important segments of state organization" (Tilly, 2004, p. 73). This definition is intended to capture major instances of regime contention and includes examples of an array of popular rebellions, civil wars, and military and other types of coups d'état. Other events, such as the riots that took place at the time when the British Parliament deliberated the Great Reform Act in 1831, are too insignificant to be counted as a 'revolutionary event' according to Tilly's definition. This does not mean that they were not important locally, but it does mean that we assume that they were unlikely to have made much of an impression abroad. Conceptually, we want to focus on (revolutionary) events that are concentrated over a short window of time, where the aim is fundamental social and political change, and where the revolt has some measure of popular support. For this reason, we have divided Tilly's catalogue of revolutionary events into two broad groups.

The first group is the revolutionary events upon which our measures of the threat of revolution are based. This includes events characterized as revolutions, revolts, insurrections and rebellions, and risings. We further divide these events into major and minor events. The minor events are those which we, based on the discussion in Tilly $(1993,2004)$, and the coverage given to them in Encyclopaedia Britannica (1911, 2009) and by Hobsbawm (1962), judge to be less likely to have made an impact abroad while the major ones clearly did. We list these events in Tables B1 (major) and $B 2$ (minor). In the estimations, we make use of both lists.

The second group includes events which we exclude from our analysis because 
we judge them to be too far away from the theoretical concept of revolution. This includes events which are characterized as independence wars, military coups or coups d'état, mutiny, civil war, foreign invasion, general strikes, and prolonged periods of (low-level) insurrections. These events are, for completeness, listed in Table B3.

[Appendix Tables B1 to B3]

\section{Data Appendix C}

Descriptive statistics of the variables used in the estimations are reported in Table $\mathrm{C} 1$, and their precise definition and sources are as follows: ${ }^{2}$

1. Suffrage is the electorate in percentage of the enfranchised age and sex group; before the women's suffrage, male population only (parliamentary elections). We assign the value of zero to suffrage for the years before the first franchise reform allowed national elections to the main legislative body based on a welldefined set of suffrage rules. In some countries these reforms were pre-dated by various elected or appointed advisory bodies. Examples of this include elections for a farmer's chamber in Sweden in the 1820s and in Denmark before the constitution of 1849. In the Netherlands, the suffrage was quite broad for a while, but was curtailed by the French and reduced under its new royal constitution after the Vienna Congress (see Congleton, 2011). No quantitative information exists for how broad these suffrages were, but the historical narrative clearly indicates that they were very narrow and often did not lead to any real influence on public policy. Sources: Flora et al. (1983), Caramani (2000), Cook and Paxton (1998), and Aidt and Jensen (2009).

2. $\mathrm{TR}_{i t}^{k}$ is the measure of the threat of revolution. For $k=u$ it is a simple count of the revolutionary events in a given year; for $k=g$, the events are weighted by the (inverse) geographic distance; for $k=l$, the events are weighted by

\footnotetext{
${ }^{2}$ For further notes on the construction of many of the control variables, see Aidt and Jensen (2009).
} 
linguistic distance, ${ }^{3}$ in all cases excluding events in each country itself. The main specification includes major events (listed in Table B1) only. For robustness, we also calculate the measures using all events including those minor ones listed in Table B2. Sources: Tilly (1993, 2004), Todd (1998), and Encyclopaedia Britannica (1911, 2009). The source used to construct linguistic distance is Fearon (2003).

3. Own revolution is a dummy variable equal to one in country $i$ in year $t$ if that country experienced a major revolutionary event in that year.

4. GDP per capita is real GDP at international 1990 Geary-Khamis dollars, adjusted to exclude the impact of border changes, per capita. Source: Maddison (2003).

5. Population is the size of the total population in 1000s. Source: Maddison (2003).

6. Agricultural share is the number of individuals employed in agriculture, mining, and fishing per 1000 employees. Source: Mitchell (2007).

7. Urbanization rate is the proportion of the population who lives in towns with more than 20,000 inhabitants. Source: Banks (2003).

8. Education attainment is a dummy coded 1 for the years after which enrollment in primary education as a percentage of all 5-14-year-olds reached $60 \%$ and 0 otherwise. Sources: Flora (1983) and Mitchell (2007).

9. Gold standard is a dummy equal to 1 if a country is on the gold standard in a given year and 0 otherwise. Sources: Meissner (2004) and EH.net encyclopedia (eh.net/encyclopedia).

10. Trade volume is exports plus imports relative to GDP. Sources: Mitchell (2007), Statistics Netherlands (1999), Buyst (1997), Krantz and Schön (2007),

\footnotetext{
${ }^{3}$ We use the dominant language group, except for Switzerland and Belgium where we base the calculation on a population weighted average. The linguistic tree contains up to 15 nested categories. We are missing information on some of the countries in the 'broader European sample' and so we cannot construct the linguistic distance weights for that sample.
} 
Grytten (2004), Flandreau and Zumer (2004), and the Swiss Economic and Social History online database (www.fsw.uzh.ch/histstat).

11. Wheat price spread is an estimate of the trade cost between two locations in a given period based on differences in wheat prices at the two locations. Source: Jacks (2005).

12. $S R N_{i t}$ is defined as a linguistic distance weighted average of franchise reforms in other countries than country $i$ in year $t$. Sources: Fearon (2003) and the sources used to define years of franchise reform recorded in Table 1.

13. War is a dummy variable equal to 1 if a country is at war and 0 otherwise. We do not include colonial wars. The available data on the size of armies have insufficient time and country coverage to be of use in our setting. Sources: Encyclopaedia Britannica (1911, 2009) and Singer and Small (1994).

14. WWI is a dummy equal to 1 during World War I (1914-18) for all countries and 0 otherwise.

15. War intensity is the number of deaths on the battle field per capita. Source: Singer and Small (1994) or http://www.correlatesofwar.org/.

16. Repression is the share of total central government spending on police, defence, general administration, and the judiciary. Source: Flora et al. (1983) and Fearon (2003).

17. Fiscal transfers is the share of total central government spending on health, education, housing, and various government-sponsored insurance and welfare programs. Source: Flora et al. (1983) and Fearon (2003).

18. Gini is the Gini coefficient for income inequality. A value of zero expresses total equality and a value of one maximal inequality. Data are available only with 20-year intervals. We have interpolated the missing observations linearly. Source: Bourguignon and Morrisson (2001, 2002). 
19. $A L_{i t}^{\text {Home }}$ is the number of 'authors of liberty' aged 20 and above who are born and living in country $i$ in year $t$ per 1000 inhabitants. Source: Potrafke and Vaubel (2011).

20. $A L_{i t}^{\text {Abroad }}$ is the number of 'authors of liberty' aged 20 and above who were born and grew up in country $i$, but at some time in adulthood emigrated to another country and in year $t$ lived outside their home country per 1000 inhabitants. Source: Potrafke and Vaubel (2011).

21. Rainfall is yearly rainfall in millimeters. The rain data is constructed for a grit by Casty et al. (2007). We have constructed the country-year data by calculating the average of rainfall in the grit cells that falls inside a country, with appropriate weighting if there is only partial overlap. The data can be downloaded from http://www.ncdc.noaa.gov/paleo/pubs/casty2007/casty2007.html

22. Rainfall, growth is the change in the logarithm of rainfall.

\section{[Table C1]}

\section{Appendix D: Robustness Checks}

1. Table D1 reports on the results of some robustness checks for the event history study where we have added additional variables.

$<$ Table D1 to appear here $>$

2. As an alternative check on the importance of enlightment shocks, we can investigate the possibility that the enlightenment shocks left in the residuals are correlated across time. To this end, we cluster the standard error by year. The result is: ${ }^{4}$

$$
\mathrm{suffrage}_{i t}=\underset{(0.013)}{0.94} \mathrm{suffrage}_{i t-1}+\ldots+\underset{(0.41)}{1.19 T R_{i t}^{g}}+\ldots
$$

\footnotetext{
${ }^{4}$ The control variables are the same as in Table 2 column five of the main text. The standard errors are shown in brackets under the coefficient estimates and are clustered by year. Similar results are obtained with the other two proxies for the threat of revolution [not reported].
} 
We observe this has little impact on the significance of the effect. If we cluster at the two-years frequency, the point estimate is unaffected (1.19) with a standard error of 0.54 .

3. Suffrage as well as several of the control variables are trending up and may be or behave as if they were non-stationary. ${ }^{5}$ To confront this issue, we estimate an Error Correction Model

$$
\begin{aligned}
\Delta \text { suffrage }_{i t}= & \lambda_{1} \Delta T R_{i t}^{g}+\Delta X_{i t} \boldsymbol{\kappa} \\
& +\rho\left(\text { suffrage }_{i t-1}-\gamma_{1} T R_{i t-1}^{g}-X_{i t-1} \boldsymbol{\omega}\right)+\varepsilon_{i t} .
\end{aligned}
$$

The term in parentheses is the long-run relation appropriately adjusted to match our other estimations, and the parameter $\rho$ captures the adjustment to the long-run equilibrium. The estimated equation is ${ }^{6}$

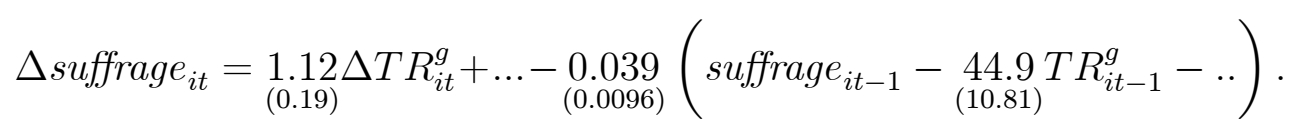

The estimates imply a significant positive short-run effect of changes in the threat of revolution on changes in suffrage and a substantial long-run effect. The negative estimate of $\rho$ implies adjustment to long-run equilibrium. All in all, our results are not an artifact of non-stationary data.

\section{References}

[1] Aidt, Toke S., and Peter S. Jensen. 2009. Tax structure, size of government and the extension of the voting franchise in Western Europe, 1860-1938. International Tax and Public Finance 16(3), 362-394.

[2] Banks, Arthur S., 2003. Cross-national time series 1815-2003. ICPSR (ed.). Inter-university Consortium for Political and Social Research, Ann Arbor, MI.

[3] Bataković, Dušan T., 2007. The road to democracy: The development of constitutionalism in Serbia 1869-1903. Balcanica 38, 133-172.

\footnotetext{
${ }^{5}$ Dickey-Fuller tests on the individual series show that we cannot, in several cases, reject nonstationarity [not reported].

${ }^{6}$ The figures in brackets underneath the coefficients are panel and AR(1) corrected standard errors, as suggested by Beck (2001). The time varying control variables are the same as in Table 2 .
} 
[4] Beck, Nathaniel, 2001. Time-series-cross-section data: what have we learned in the past few years? Annual Review of Political Science 4, 271-293.

[5] Bourguignon, Francois. and Christian Morrisson, 2001. Data sources for inequality among world Citizens, 1820-1992" [computer file]. Unpublished, available at www.delta.ens.fr/XIX

[6] Bourguignon, Francois. and Christian Morrisson, 2002. Inequality among world citizens 1820-1992. American Economic Review 92(4), 727-744.

[7] Buyst, Erik, 1997. New GNP estimates for the Belgian economy during the interwar period. Review of Income and Wealth Series 43(3), 357-375.

[8] Campbell, Peter, 1958. French Electoral Systems and Elections since 1789. London: Faber and Faber Ltd.

[9] Casty, Carlo, Raible, Christoph C., Stocker, Thomas F., Wanner, Heinz, Luterbacher, Jürg. 2007. A European pattern climatology 1766-2000. Journal Climate Dynamics 29(7-8), 791-805.

[10] Caramani, Daniele, 2000. Elections in Western Europe since 1815. Electoral results by constituencies. Palgrave Macmillan Publishers Ltd. Houndmills, Basingstoke, Hampshire, UK.

[11] Carstairs, Andrew M., 1980. A short history of electoral systems in Western Europe. George Allen \& Unwin, London.

[12] Cook, Chris, and John Paxton, 1998. European political facts. MacMillan Press, London.

[13] Encyclopaedia Britannica, 1911, 11th edition. Cambridge University Press, Cambridge, UK.

[14] Encyclopaedia Britannica, 2009, 15th edition. Cambridge University Press, Cambridge, UK.

[15] Fearon, James, 2003. Ethnic and cultural diversity by country. Journal of Economic Growth 8, 1995-2222.

[16] Flandreau, Marc, and Frédéric Zumer, 2004. The making of global finance, OECD, Paris.

[17] Flora, Peter, with Jens Alber, Richard Eichenberg, Jürgen Kohl, Franz Kraus, Winfried Pfenning, and Kurt Seebohm, 1983. State, economy and society in Western Europe 1815-1975, Vol. I. Campus Verlag, Frankfurt, Germany.

[18] Flora, Peter, with Jens Alber, Richard Eichenberg, Jürgen Kohl, Franz Kraus, Winfried Pfenning, and Kurt Seebohm, 1987. State, economy, and society in Western Europe 1815-1975, Vol. II. Macmillan Press, London. 
[19] Grytten, Ola H., 2004. The gross domestic product for Norway, 1830-2003. Norges Bank: Occasional Papers, no. 1, 241-288.

[20] Hobsbawm, Eric, 1962. The age of revolution, 1789-1848. London: Weidenfeld and Nicholson.

[21] Jacks, David S., 2005. Intra- and international commodity market integration in the Atlantic economy, 1800-1913. Explorations in Economic History 42, 381413.

[22] Krantz, Olle, and Lennart Schön, 2007. Swedish historical national accounts, 1800-2000. Almqvist and Wiksell International.

[23] Mackie, Thomas T. and Richard Rose, 1991. The International Almanac of Electoral History. London: Macmillan, 3rd edition.

[24] Maddison, Angus, 2003. The world economy: Historical statistics. OECD, Paris.

[25] Meissner, Christopher M., 2004. A new world order: explaining the international diffusion of the gold standard, 1870-1913. Journal of International Economics $66,385-406$.

[26] Mitchell, Brian R., 2007. International historical statistics: Europe, 1750-2005. 6th ed., MacMillan Basingstoke, UK.

[27] Potrafke, Niklas and Roland Vaubel, 2011. The interjurisdictional migration of European authors of liberty, 1660-1961: A quantitative analysis. Unpublished working paper, University of Konstanz.

[28] Ortega, José V., and Rogelio A.L. Blanco, 1990. Historiography, sources and methods for the study of electoral laws in Spain. In: S. Noiret (ed.), Political strategies and electoral reforms: Origins of voting systems in Europe in the 19th and 20th century. Nomos Verlagsgesellschaft, Baden-Baden.

[29] Seymour, Charles, and Donald P. Frary, 1918. How the world votes: The story of democratic development in elections. C. A. Nichols: Springfield, Massachusetts.

[30] Singer, J. David, and Melvin Small, 1994. Correlates of war project: International and civil war data, 1816-1992. Inter-University Consortium for Political and Social Research, Ann Arbor, Michigan.

[31] Statistics Netherlands, 1999. Tweehonderd jaar statistiek, 1800-1999. Amsterdam.

[32] Tilly, Charles, 1993. European revolutions: 1492-1992. Wiley-Blackwell, Oxford, UK.

[33] Tilly, Charles, 2004. Contention and Democracy in Europe, 1650-2000. Cambridge University Press, Cambridge, UK. 
[34] Todd, Allan, 1998. Revolutions, 1789-191\%. Cambridge University Press, Cambridge, UK. 


\section{The Western European sample}

Table A1. The United Kingdom (in sample from 1820)

\begin{tabular}{|c|c|c|}
\hline Year & Franchise extensions/contractions & Other features \\
\hline $\begin{array}{l}\text { Pre- } \\
1832\end{array}$ & $\begin{array}{l}\text { Restricted and unequal manhood suffrage with } \\
\text { relatively high, but locally different, economic } \\
\text { requirement. }\end{array}$ & $\begin{array}{l}\text { Electoral corruption } \\
\text { widespread. }\end{array}$ \\
\hline 1832 & $\begin{array}{l}\text { The Great Reform Act. Reduction and standardization } \\
\text { of income and property qualifications. The process } \\
\text { started with Lord Grey's government formed in } \\
\text { November } 1830 \text {. }\end{array}$ & Redistribution of seats. \\
\hline 1867 & $\begin{array}{l}\text { The Second Reform Act. Reduction of income and } \\
\text { property requirements. }\end{array}$ & Redistribution of seats. \\
\hline 1872 & & The Secret Ballot. \\
\hline 1884 & $\begin{array}{l}\text { The Third Reform Act. Reduction and standardization } \\
\text { of economic qualifications for the county and borough } \\
\text { constituencies. }\end{array}$ & $\begin{array}{l}\text { Redistribution of seats and } \\
\text { single member districts as a } \\
\text { rule. }\end{array}$ \\
\hline 1918 & $\begin{array}{l}\text { The Fourth Reform Act. Universal and almost equal } \\
\text { suffrage for male citizens over 21. The process had } \\
\text { started in } 1912 \text { with Asquith's Liberal government } \\
\text { introducing the Franchise and Distribution Act. This } \\
\text { proposed to increase the number of male voters, but did } \\
\text { not include rights for women. The Speaker's } \\
\text { Conference of } 1916 \text { recommended universal male } \\
\text { suffrage, votes for women and some proportional } \\
\text { representation. }\end{array}$ & $\begin{array}{l}\text { This includes the right to } \\
\text { vote for married women } \\
\text { above } 30 \text { years and over } \\
\text { who are householders or } \\
\text { wives of householders. } \\
\text { Redistribution of seats. }\end{array}$ \\
\hline 1928 & & Women’s suffrage. \\
\hline
\end{tabular}


Table A2: Austria (in sample from 1867; regress to autocracy in 1934)

\begin{tabular}{|c|c|c|}
\hline Year & Franchise extensions/contractions & Other features \\
\hline $\begin{array}{l}1815- \\
1866\end{array}$ & & $\begin{array}{l}\text { Member of the German Confederation (which } \\
\text { the Austrian Empire established after the } \\
\text { defeat of Napoleon). }\end{array}$ \\
\hline 1866 & & $\begin{array}{l}\text { War with Prussia in } 1866 \text { dissolves the } \\
\text { Confederation and Austria remains outside } \\
\text { the German Empire established amongst the } \\
\text { other German states in } 1871 \text { under the } \\
\text { leadership of Prussia. }\end{array}$ \\
\hline 1867 & & $\begin{array}{l}\text { The Austro-Hungarian Compromise of } 1867 \text {, } \\
\text { under which the House of Habsburg agreed to } \\
\text { share power with a separate Hungarian } \\
\text { government, dividing the territory of the } \\
\text { former Austrian Empire between them. The } \\
\text { Austrian and the Hungarian lands became } \\
\text { independent entities enjoying equal status and } \\
\text { we treat the two as independent units in the } \\
\text { extended sample from } 1867 \text {. }\end{array}$ \\
\hline 1867 & $\begin{array}{l}\text { The Constitution of } 1867 \text { introduced } \\
\text { restricted and unequal manhood } \\
\text { suffrage in four electoral classes } \\
\text { (curia): } \\
\text { a) Great landowners who paid } \\
\text { a minimum on estates. } \\
\text { b) Members of chambers of } \\
\text { commerce and trade. } \\
\text { c) } 24 \text { year old male inhabitants } \\
\text { of towns and cities who paid } \\
\text { minimum direct taxes. } \\
\text { d) } 24 \text { year old male inhabitants } \\
\text { of rural communes who paid } \\
\text { minimum direct taxes. }\end{array}$ & $\begin{array}{l}\text { Bicameral imperial parliament with an upper } \\
\text { house and a house of representatives, the } \\
\text { latter elected indirectly by the Landtags, but } \\
\text { with the provision that a direct election could } \\
\text { be held if a Landtag (provincial assembly) did } \\
\text { not send representatives. }\end{array}$ \\
\hline 1873 & Unchanged & $\begin{array}{l}\text { All elections for the lower chamber were } \\
\text { direct. }\end{array}$ \\
\hline 1896 & $\begin{array}{l}\text { Additional fifth curia introduced in } \\
\text { which there was universal and equal } \\
\text { suffrage for male citizens over } 24 ; \\
\text { electors of the first four curia gained } \\
\text { a second vote. }\end{array}$ & \\
\hline 1907 & $\begin{array}{l}\text { Universal and equal suffrage for } \\
\text { male citizens over } 24 \text {. The curial } \\
\text { system abolished. }\end{array}$ & $\begin{array}{l}\text { Street demonstrations. Direct elections. Secret } \\
\text { ballot, compulsory voting in four provinces. } \\
\text { Majority representation, single-member } \\
\text { constituencies. }\end{array}$ \\
\hline 1918 & & $\begin{array}{l}\text { Declaration of German Austria as a } \\
\text { democratic republic. }\end{array}$ \\
\hline 1919 & $\begin{array}{l}\text { Universal and equal suffrage for } \\
\text { men and women over the age of } 20 \text {. }\end{array}$ & $\begin{array}{l}\text { Proportional representation. Women's } \\
\text { suffrage. Secret ballot. Compulsory voting in } \\
\text { two provinces. }\end{array}$ \\
\hline 1920 & Unchanged & Federal structure, with Nationalrat (lower \\
\hline
\end{tabular}




\begin{tabular}{|l|l|l|}
\hline & & $\begin{array}{l}\text { house) which was directly elected by } \\
\text { universal suffrage and an upper house } \\
\text { (Bundesrat) which represented the Lander } \\
\text { (states). }\end{array}$ \\
\hline 1929 & Unchanged & $\begin{array}{l}\text { Direct election of the president by the } \\
\text { enfranchised population instead of by } \\
\text { parliament, but no presidential election held } \\
\text { till 1951. }\end{array}$ \\
\hline 1934 & & Nazi party takes over. \\
\hline
\end{tabular}

Table A3: Italy (in the sample from 1861, regress to autocracy in $1924^{1}$ ).

\begin{tabular}{|c|c|c|}
\hline Year & Franchise extensions/contractions & Other features \\
\hline $\begin{array}{l}1820- \\
1860\end{array}$ & $\begin{array}{l}\text { The individual Italian states had their own } \\
\text { constitutions. }\end{array}$ & $\begin{array}{l}\text { By 1860, there were four Italian } \\
\text { states (the Austrians in Venetia, the } \\
\text { Papal States, the Kingdom of } \\
\text { Piedmont-Sardinia, and the Kingdom } \\
\text { of the Two Sicilies). On March 17, } \\
1861 \text {, the Parliament proclaimed } \\
\text { Victor Emmanuel II King of Italy } \\
\text { and the Kingdom of Italy was } \\
\text { established. Venetia and the Papal } \\
\text { States (Rome) were not integrated till } \\
1866 \text { and } 1870 \text {, respectively. }\end{array}$ \\
\hline 1861 & $\begin{array}{l}\text { Equal but restricted manhood suffrage; } \\
\text { limited to citizens of } 25 \text { years and over who } \\
\text { paid minimum direct taxes and who could } \\
\text { read and write. }\end{array}$ & $\begin{array}{l}\text { Direct elections with secret ballot, } \\
\text { Majority representation in single } \\
\text { member districts. }\end{array}$ \\
\hline 1882 & $\begin{array}{l}\text { Equal but restricted manhood suffrage; } \\
\text { limited to citizens of } 21 \text { years and over; } \\
\text { same restrictions as in } 1861 \text { except that tax } \\
\text { minima and equivalent wealth requirement } \\
\text { were reduced and suffrage granted to higher } \\
\text { officials and other citizens with certain } \\
\text { educational qualifications without further } \\
\text { census restrictions. }\end{array}$ & $\begin{array}{l}\text { Direct elections with secret ballot. } \\
\text { Majority rule. Majority } \\
\text { representation in multi member } \\
\text { districts. }\end{array}$ \\
\hline 1894 & & $\begin{array}{l}\text { Revision of electoral registers } \\
\text { resulted in a considerable reduction } \\
\text { in the size of the electorate. }\end{array}$ \\
\hline 1912 & $\begin{array}{l}\text { Almost universal and equal suffrage for } \\
\text { male citizens of } 30 \text { years and over and in } \\
\text { addition for male citizens of } 21 \text { years and } \\
\text { over, who had completed their military } \\
\text { service, or had finished primary school, paid } \\
\text { minimum tax, and exercised official } \\
\text { functions. }\end{array}$ & $\begin{array}{l}\text { Direct elections with secret ballot. } \\
\text { Majority rule. Majority } \\
\text { representation in multi member } \\
\text { districts. }\end{array}$ \\
\hline 1919 & $\begin{array}{l}\text { Universal and equal manhood suffrage for } \\
\text { citizens of } 21 \text { years and over, in addition }\end{array}$ & $\begin{array}{l}\text { Direct elections with secret ballot. } \\
\text { Proportional representation. }\end{array}$ \\
\hline
\end{tabular}

\footnotetext{
${ }^{1}$ We let Italy exit in 1924. In 1923, the Acerbo law had been passed, which effectively allowed Mussolini to be a sure winner of the 1924 election, and thus after 1923, Italy was effectively non-democratic.
} 


\begin{tabular}{|l|l|l|}
\hline & $\begin{array}{l}\text { suffrage for all men who participated in the } \\
\text { war without age restrictions. }\end{array}$ & \\
\hline 1924 & & Mussolini. \\
\hline$(1946)$ & $\begin{array}{l}\text { Universal and equal suffrage for all citizens } \\
\text { of 21 years and over. }\end{array}$ & Women’s suffrage. \\
\hline
\end{tabular}

Table A4: Norway (in the sample from 1820).

\begin{tabular}{|c|c|c|}
\hline Year & Franchise extensions/contractions & Other features \\
\hline$(1814)$ & $\begin{array}{l}\text { Equal but restricted manhood suffrage } \\
\text { with relatively high occupational and } \\
\text { property requirements. }\end{array}$ & $\begin{array}{l}\text { Norway did not gain full independence } \\
\text { until 1905. However, during the Union } \\
\text { with Sweden, it kept its liberal constitution } \\
\text { and independent institutions, except for the } \\
\text { foreign service, and could control its } \\
\text { franchise rules. Indirect elections with open } \\
\text { voting; majority representation. }\end{array}$ \\
\hline 1884 & $\begin{array}{l}\text { Extension of the franchise to citizens } \\
\text { paying taxes on income above given } \\
\text { minima. }\end{array}$ & Secret ballot. \\
\hline 1897 & $\begin{array}{l}\text { Almost universal and equal suffrage } \\
\text { for male citizens of } 25 \text { years and } \\
\text { overs. Suffrage suspended in cases of } \\
\text { bankruptcy and for paupers receiving } \\
\text { public assistance. }\end{array}$ & $\begin{array}{l}\text { Indirect, secret ballot. Majority } \\
\text { representation. }\end{array}$ \\
\hline 1905 & & Union with Sweden dissolved. \\
\hline 1905 & & Direct elections. \\
\hline 1907 & $\begin{array}{l}\text { Extension of suffrage to women if } \\
\text { own or husband's income exceeded } \\
\text { minima. }\end{array}$ & $\begin{array}{l}\text { (This has caused an artificial drop in } \\
\text { suffrage as recorded by Flora et al. (1983) } \\
\text { which we have corrected.) }\end{array}$ \\
\hline 1913 & $\begin{array}{l}\text { Almost universal and equal suffrage } \\
\text { for men and women of } 25 \text { years and } \\
\text { over. Suspended only for paupers. }\end{array}$ & Women’s suffrage. \\
\hline 1919 & $\begin{array}{l}\text { Lowering of the voting age from } 25 \text { to } \\
\text { 23. Paupers allowed to vote. }\end{array}$ & Proportional representation. \\
\hline
\end{tabular}


Table A5: The Netherlands (in the sample from 1830).

\begin{tabular}{|c|c|c|}
\hline Year & Franchise extensions/contractions & Other features \\
\hline$(1815)$ & $\begin{array}{l}\text { The members of the lower chamber were } \\
\text { elected by the } 18 \text { provincial councils } \\
\text { which consisted of different Estates. }\end{array}$ & $\begin{array}{l}\text { The union with Belgium established in } \\
1814 \text { was codified in the constitution } \\
\text { adopted in } 1815 \text {. This constitution } \\
\text { established a two-chamber system. The } \\
\text { upper chamber was nominated by the } \\
\text { Crown. The lower chamber was } \\
\text { indirectly elected and initially intended to } \\
\text { have equal representation from the } \\
\text { Netherlands and from Belgium. }\end{array}$ \\
\hline 1830 & Unchanged & $\begin{array}{l}\text { The Belgian Revolution; the union with } \\
\text { Belgium dissolved. }\end{array}$ \\
\hline 1840 & Unchanged & $\begin{array}{l}\text { After the independence of Belgium in } \\
1830 \text {, a revision of the constitution was } \\
\text { adopted in 1840, but both the } 1815 \text { and } \\
1840 \text { constitutions were based on the } \\
\text { same franchise rules and indirect } \\
\text { elections. As a consequence, the } \\
\text { constitution of } 1840 \text { does not represent a } \\
\text { franchise extension, just an adjustment of } \\
\text { the existing rules to accommodate the } \\
\text { fact that Belgium no longer was part of } \\
\text { the Union. }\end{array}$ \\
\hline 1848 & $\begin{array}{l}\text { Equal but restricted manhood suffrage } \\
\text { for citizens of } 23 \text { years and over. Vote } \\
\text { contingent on surpassing relatively high } \\
\text { direct tax minima. }\end{array}$ & $\begin{array}{l}\text { Direct elections with secret ballot. } \\
\text { Majority representation. } \\
\text { 1848-68: the powers of the elected } \\
\text { parliament were de facto in question till } \\
1868 \text {. }\end{array}$ \\
\hline 1887 & $\begin{array}{l}\text { The right to vote was made dependent } \\
\text { on education and property. The franchise } \\
\text { was expanded, to about } 29 \% \text { of adult } \\
\text { men. The direct tax minima and } \\
\text { equivalent requirement of renting or } \\
\text { owing a house a above a certain rental } \\
\text { value reduced. }\end{array}$ & \\
\hline 1894 & $\begin{array}{l}\text { Equal but restricted suffrage for male } \\
\text { citizens of } 25 \text { years and over, with } \\
\text { relatively low qualifications. }\end{array}$ & \\
\hline 1917 & $\begin{array}{l}\text { Universal male suffrage with voting age } \\
\text { of 25. Pacification Act of } 1917 \text {. Autumn. }\end{array}$ & $\begin{array}{l}\text { Direct elections. Proportional } \\
\text { representation. Compulsory voting. In } \\
\text { 1917, like in } 1848 \text { influenced by the } \\
\text { tense international situation, manhood } \\
\text { suffrage was introduced combined with a } \\
\text { system of proportional representation to } \\
\text { elect the House of Representatives, the } \\
\text { States-Provincial and the municipality } \\
\text { councils. By the revision of } 1922 \\
\text { universal suffrage was explicitly adopted } \\
\text { in the constitution, after it had already }\end{array}$ \\
\hline
\end{tabular}




\begin{tabular}{|l|l|l|}
\hline 1922 & $\begin{array}{l}\text { Universal suffrage with voting age of } \\
25 .\end{array}$ & been introduced by law in 1919 \\
\hline
\end{tabular}

Table A6: Sweden (in sample from 1820)

\begin{tabular}{|c|c|c|}
\hline Year & Franchise extensions/contractions & Other features \\
\hline$(1809)$ & $\begin{array}{l}\text { Four estate system with some form of election to the } \\
\text { Estate of Farmers and the Estate of Burghers. }\end{array}$ & \\
\hline 1866 & $\begin{array}{l}\text { Equal but restricted manhood suffrage with } \\
\text { relatively high economic qualifications. } \\
\text { Alternatively, property above a certain value; } \\
\text { leasing of farmland above a certain value; income } \\
\text { above given minima. Voting age } 21 \text {. }\end{array}$ & $\begin{array}{l}\text { Partly direct, partly indirect } \\
\text { elections. Secret ballot. } \\
\text { Majority representation, } \\
\text { mostly in single-member } \\
\text { constituencies. }\end{array}$ \\
\hline 1907 & $\begin{array}{l}\text { Almost universal and equal suffrage for male } \\
\text { citizens of } 24 \text { years and over, excluding recipients } \\
\text { of public poor relief. }\end{array}$ & $\begin{array}{l}\text { Direct elections; secret ballot; } \\
\text { proportional representation. }\end{array}$ \\
\hline 1919 & $\begin{array}{l}\text { Universal and equal suffrage for men and women of } \\
23 \text { years and over. Recipients of public poor relief } \\
\text { enfranchised. }\end{array}$ & $\begin{array}{l}\text { Women's suffrage. Adopted } \\
\text { in special session of the } \\
\text { parliament in December } 1918 .\end{array}$ \\
\hline
\end{tabular}

Table A7: France (in sample from 1820).

\begin{tabular}{|l|l|l|}
\hline Year & Franchise extensions/contractions & Other features \\
\hline (1815) & $\begin{array}{l}\text { Almost universal and equal manhood } \\
\text { suffrage (excluding dependents) for primary } \\
\text { elections. Restricted and unequal manhood } \\
\text { suffrage in the electoral colleges because of } \\
\text { strict criteria of eligibility. }\end{array}$ & $\begin{array}{l}\text { Indirect elections. Primary } \\
\text { assemblies elect lifetime members of } \\
\text { electoral college. Electoral college } \\
\text { elect member of parliament. } \\
\text { Majority representation at both } \\
\text { stages. }\end{array}$ \\
\hline $\mathbf{1 8 2 0}$ & $\begin{array}{l}\text { Restricted and unequal suffrage for male } \\
\text { citizens of 30 years and over. General } \\
\text { electorate restricted by high direct tax } \\
\text { minima; the upper 25\% of the general } \\
\text { electorate paying higher direct taxes } \\
\text { constituted an additional electoral body. } \\
\text { Under Richelieu, the franchise was changed } \\
\text { to give the wealthiest electors a double vote, } \\
\text { in time for the November 1820 election. }\end{array}$ & $\begin{array}{l}\text { Direct elections: the general } \\
\text { electorate elects 60\% of member of } \\
\text { parliament; the remaining 40\% are } \\
\text { elected by the assemblies of higher } \\
\text { taxpayers. No strict provision for } \\
\text { secrecy. Majority representation: } \\
\text { absolute majority system in single } \\
\text { member constituencies with third } \\
\text { ballot run-off between top two } \\
\text { candidates. } \\
\text { Charles X dissolved the Chamber in }\end{array}$ \\
\hline $\mathbf{1 8 3 0}$ & $\begin{array}{l}\text { The Constitution of 1830 and the electoral } \\
\text { law of 1831 introduce restricted but almost } \\
\text { equal manhood suffrage for citizens of 25 } \\
\text { years and over; reduced direct tax minima. } \\
\text { The property qualification was reduced to } \\
\text { include everyone who paid a direct tax of } \\
\text { 200 (formerly 300) francs. }\end{array}$ & $\begin{array}{l}\text { Dower of the Chamber was curtailed. } \\
\text { Dajoct elections with secret ballot. } \\
\text { majority system as before. }\end{array}$ \\
\hline
\end{tabular}




\begin{tabular}{|c|c|c|}
\hline & $\begin{array}{l}\text { citizens of } 21 \text { years and over. (The Second } \\
\text { Republic). }\end{array}$ & \\
\hline $\begin{array}{l}1852- \\
1869\end{array}$ & $\begin{array}{l}\text { The de jure franchise rules were not } \\
\text { changed. }\end{array}$ & $\begin{array}{l}\text { During the Second Empire from } \\
1852 \text { to } 1869 \text {, elections were } \\
\text { systematically manipulated by the } \\
\text { government to secure the return of } \\
\text { compliant body of members. }\end{array}$ \\
\hline 1870 & $\begin{array}{l}\text { Reintroduction of the suffrage rules from the } \\
\text { Second Republic. These had formally been } \\
\text { in operation during the Second Empire, so } \\
\text { the franchise rules were not changed de jure. } \\
\text { We count this as a reform year in the } \\
\text { specifications where we take franchise } \\
\text { contractions into account, but not in those } \\
\text { where we don't. }\end{array}$ & $\begin{array}{l}\text { The Third Republic: elections were } \\
\text { able to function freely and fairly. }\end{array}$ \\
\hline (1945) & $\begin{array}{l}\text { Universal and equal suffrage for all men and } \\
\text { women of } 21 \text { years and over. }\end{array}$ & $\begin{array}{l}\text { Women's suffrage. Direct elections } \\
\text { with secret ballot. Proportional } \\
\text { representation in multi-member } \\
\text { constituencies till } 1951 \text {. }\end{array}$ \\
\hline
\end{tabular}

Table A8: Germany (in sample from 1871, regresses to autocracy in 1933-34²).

\begin{tabular}{|l|l|l|}
\hline Year & $\begin{array}{l}\text { Franchise } \\
\text { extensions/contractions }\end{array}$ & Other features \\
\hline $1815-$ & $\begin{array}{l}\text { No directly elected assembly } \\
\text { at the confederal level. Each } \\
\text { of the 41 member states had } \\
\text { their own suffrage rules and } \\
\text { there were direct elections to } \\
\text { state assemblies in some } \\
\text { states. }\end{array}$ & $\begin{array}{l}\text { The (Second) Germany Confederation. It was } \\
\text { established at the Vienna Congress and reduced the } \\
\text { number of independent German polities to 41. The } \\
\text { two dominant powers were Prussia and Austria. The } \\
\text { confederation was governed by a diet, a council of } \\
\text { state, and a prime minister. Each state selected a } \\
\text { representative to the diet (where a weighted voting } \\
\text { system was used to make decisions). The states of } \\
\text { the confederation retained most powers and could } \\
\text { decide on their own constitutional rules, but the } \\
\text { confederation required the states to adopt written } \\
\text { constitutions. The federation could not raise taxes } \\
\text { and was charged with the task of securing internal } \\
\text { and external security. }\end{array}$ \\
\hline $1848-$ & $\begin{array}{l}\text { Elected parliament proposed } \\
\text { but not adopted. Many states } \\
\text { liberalized their suffrage } \\
\text { rules. }\end{array}$ & $\begin{array}{l}\text { An attempt to reform the German confederal } \\
\text { government was made in 1848-49 at the } \\
\text { constitutional convention in Frankfurt. The members } \\
\text { of the convention were elected on a broad suffrage } \\
\text { that included wealth or tax-payment thresholds } \\
\text { similar to those used by many state elections for } \\
\text { their lower chambers. The convention could propose } \\
\text { but not adopt reform. It proposed a constitutional } \\
\text { monarchy for Germany with an elected parliament }\end{array}$ \\
\hline
\end{tabular}

\footnotetext{
${ }^{2}$ We code Germany as democratic in 1933 since elections were held in that year. Accordingly, Germany exits in 1934 when it effectively became a dictatorship.
} 


\begin{tabular}{|c|c|c|}
\hline & & $\begin{array}{l}\text { and ministers responsible to parliament and a new } \\
\text { German crown (offered to the King of Prussia). The } \\
\text { King of Prussia refused and the attempt at reform } \\
\text { stopped there. }\end{array}$ \\
\hline 1866 & & $\begin{array}{l}\text { War between Austria and Prussia breaks the } \\
\text { confederation up. }\end{array}$ \\
\hline 1867 & $\begin{array}{l}\text { Similar to those applicable } \\
\text { during the German Empire. }\end{array}$ & $\begin{array}{l}\text { Northern German Confederation established by } \\
\text { Prussia. }\end{array}$ \\
\hline 1871 & $\begin{array}{l}\text { Universal and equal suffrage } \\
\text { for all male citizens of } 25 \\
\text { years and over in elections to } \\
\text { the Reichstag. } \\
\text { Each of the } 25 \text { member states } \\
\text { had their own constitutions } \\
\text { and rules for elections to their } \\
\text { parliaments. }\end{array}$ & $\begin{array}{l}\text { Imperial Germany established when the southern } \\
\text { states join the Northern German Confederation. } \\
\text { Austria did not join and is treated as independent } \\
\text { from } 1867 \text {. Electoral corruption widespread. Direct } \\
\text { elections, majority rule. The government was not } \\
\text { constitutionally responsible to parliament. Under the } \\
\text { constitution of 1871, executive power lay with the } \\
\text { Bundesrat. The Bundesrat consisted of } \\
\text { representatives of the member states according to a } \\
\text { system of population weighting. This gave Prussia } \\
\text { dominant influence. The appointment of the German } \\
\text { Chancellor was retained by the King of Germany } \\
\text { (and Prussia). The main duty of the central } \\
\text { government was initially defense and the chancellor } \\
\text { had control over the military and over foreign } \\
\text { policy. This restricted the de facto influence of the } \\
\text { electorate on federal policy and since the state } \\
\text { constitutions often used wealth restrictions, voters } \\
\text { also had limited influence on state policy. In } \\
\text { practice, great powers were granted to the emperor, } \\
\text { as the president of the federal council. The } \\
\text { Reichstag was elected by universal and direct } \\
\text { election with a secret ballot. }\end{array}$ \\
\hline 1919 & $\begin{array}{l}\text { Universal and equal suffrage } \\
\text { for men and women of } 20 \\
\text { years and over. } \\
\text { All states (Länder) adopt this } \\
\text { suffrage. }\end{array}$ & $\begin{array}{l}\text { The Weimar Republic. Direct and secret elections. } \\
\text { Proportional representation. Women's suffrage. The } \\
\text { constitution of the German Empire adopted in } 1871 \\
\text { required that the Reichtag (the lower chamber) was } \\
\text { elected by universal and direct election with a secret } \\
\text { ballot. The Duchies, Kingdoms, and Free Cities, } \\
\text { however, had their own constitutions and these } \\
\text { typically prescribed that their lower chambers were } \\
\text { elected on a wealth-based suffrage. The most } \\
\text { important example of the three class system is the } \\
\text { one operating in Prussia from } 1848 \text { till 1919. The } \\
\text { Weimar Constitution required that the delegates [of } \\
\text { the Reichstag] are elected by universal, equal, direct, } \\
\text { and secret suffrage by men and women over twenty } \\
\text { years of age, according to the principle of } \\
\text { proportional representation and as pointed out by } \\
\text { Congleton (2011, p. } 479 \text { ), the “final step to } \\
\text { parliamentary democracy in Germany required a } \\
\text { substantial increase in parliament's authority over }\end{array}$ \\
\hline
\end{tabular}




\begin{tabular}{|c|c|}
\hline & $\begin{array}{l}\text { public policy, rather than suffrage expansion”. } \\
\text { However, the Weimar Constitution (Article 17) } \\
\text { required that every state must have a republican } \\
\text { constitution and that all representatives must be } \\
\text { elected according to the same rules as for the } \\
\text { Reichstag. This implies that the Weimar } \\
\text { Constitution extended the franchise in the states and } \\
\text { as such can be viewed as a de jure franchise } \\
\text { extension. This coding choice does not affect any of } \\
\text { our results. }\end{array}$ \\
\hline 1933 & $\begin{array}{l}\text { Though It did not obtain a majority in the Reichstag } \\
\text { in March 1933, the Nazi government was able to } \\
\text { pass the Enabling Act which effectively ended } \\
\text { democracy. The Weimar Constitution of } 1919 \text { was } \\
\text { never officially repealed, but the legal measures } \\
\text { taken by the Nazi government in March } 1933 \text { meant } \\
\text { that the constitution became irrelevant. }\end{array}$ \\
\hline
\end{tabular}

Table A9: Finland (in the sample from 1820).

\begin{tabular}{|c|c|c|}
\hline Year & Franchise extensions/contractions & Other features \\
\hline 1820 & & $\begin{array}{l}\text { Finland was an autonomous Grand } \\
\text { Duchy of the Russian Empire from } \\
\text { the end of the Finnish War between } \\
\text { Sweden and Russia in } 1809 \text { until } \\
1917 \text { when full independence was } \\
\text { achieved. The old four-chamber Diet } \\
\text { was re-activated in the 1860s and } \\
\text { made new legislation concerning } \\
\text { internal affairs. } \\
\text { We let Finland enter the sample in } \\
\text { 1820, but none of the results } \\
\text { depends on this choice. }\end{array}$ \\
\hline 1869 & $\begin{array}{l}\text { The Diet Act of } 1869 \text { introduced a restricted } \\
\text { and unequal franchise to the Diet based on } 4 \\
\text { estates: nobility, clergy, town, and peasants. In } \\
\text { the estate of burgesses, plural voting according } \\
\text { to local taxes paid; in the estate of peasants, the } \\
\text { suffrage was restricted to owners of real estate } \\
\text { or leaseholders. }\end{array}$ & $\begin{array}{l}\text { Direct elections to the estate of } \\
\text { burgesses, indirect elections to the } \\
\text { estate of peasants. No provisions for } \\
\text { secrecy. }\end{array}$ \\
\hline 1906 & $\begin{array}{l}\text { Universal and equal suffrage for all men and } \\
\text { women over } 24 \text { years. } \\
\text { The process that led to the November } \\
\text { Manifesto and the parliament of Finland } \\
\text { started with a general strike of } 1905 \text { (12-19 } \\
\text { November). During the general strike, the Red } \\
\text { Declaration, written by Finnish politician and } \\
\text { journalist Yrjö Mäkelin, was given in } \\
\text { Tampere, demanding dissolution of the Senate } \\
\text { of Finland, universal suffrage, political } \\
\text { freedoms, and abolition of censorship. Leader }\end{array}$ & $\begin{array}{l}\text { The Diet was replaced by the } \\
\text { Parliament of Finland. Direct } \\
\text { elections with secret ballot. } \\
\text { Proportional representation in multi- } \\
\text { member constituencies. Women's } \\
\text { suffrage. }\end{array}$ \\
\hline
\end{tabular}




\begin{tabular}{|l|l|l|}
\hline $\begin{array}{l}\text { of the constitutionalists, Leo Mechelin crafted } \\
\text { the November Manifesto that led to the } \\
\text { abolition of the Diet of Finland and of the four } \\
\text { Estates, and to the creation of the modern } \\
\text { Parliament of Finland. }\end{array}$ & \\
\hline
\end{tabular}

Table A10: Belgium (in the sample from 1830).

\begin{tabular}{|c|c|c|}
\hline Year & Franchise extensions/contractions & Other features \\
\hline 1830 & & Independence from the Netherlands. \\
\hline 1831 & $\begin{array}{l}\text { Equal but restricted manhood suffrage with } \\
\text { high direct tax minima differing in urban } \\
\text { and rural areas. Voting age } 25 \text {. }\end{array}$ & $\begin{array}{l}\text { Leopold I enthroned as king on 21st } \\
\text { July } 1831 \text {. Constitutional monarchy. } \\
\text { Direct elections but no provision for } \\
\text { secrecy. Majority representation in } \\
\text { multi-member constituencies; } \\
\text { absolute majority required on first } \\
\text { ballot, relative majority on second } \\
\text { ballot. On } 20 \text { December, } 1830 \text { at the } \\
\text { London Conference of } 1830 \\
\text { Belgium's independence recognized. }\end{array}$ \\
\hline 1848 & $\begin{array}{l}\text { Reduction and standardization of direct tax } \\
\text { minima. }\end{array}$ & \\
\hline 1871 & Voting age reduced to 21 & \\
\hline 1877 & & Secret ballot. \\
\hline 1893 & $\begin{array}{l}\text { Universal but unequal manhood suffrage. } \\
\text { Plural voting with one additional vote for } \\
\text { house owners and owners of real estate } \\
\text { above a certain minima; two additional } \\
\text { votes for citizens with higher education } \\
\text { diploma and certain officials; maximum } \\
\text { votes per person is } 3 \text { and minimum voting } \\
\text { age is } 21 \text {. }\end{array}$ & $\begin{array}{l}\text { Direct elections with secret ballot. } \\
\text { Compulsory voting; majority } \\
\text { representation as before. }\end{array}$ \\
\hline 1899 & & Proportional representation \\
\hline 1919 & $\begin{array}{l}\text { Universal and equal manhood suffrage for } \\
\text { men over } 21 \text {. Plural voting abolished. } \\
\text { Suffrage for mothers and widows of } \\
\text { soldiers who had died in the war. }\end{array}$ & $\begin{array}{l}\text { Direct elections with secret ballot. } \\
\text { Compulsory voting. Proportional } \\
\text { representation. }\end{array}$ \\
\hline (1948) & $\begin{array}{l}\text { Universal and equal suffrage for all men } \\
\text { and women over } 21 \text {. }\end{array}$ & Women’s suffrage. \\
\hline
\end{tabular}


Table A11: Switzerland (in sample from 1848)

\begin{tabular}{|c|c|c|}
\hline Year & Franchise extensions/contractions & Other features \\
\hline 1830 & $\begin{array}{l}\text { The cantons had their own } \\
\text { constitutional arrangements. }\end{array}$ & $\begin{array}{l}\text { "The July Revolution of 1830” in France } \\
\text { launched a liberal movement in Europe } \\
\text { which in Switzerland had the aim of } \\
\text { transforming the union of separate and } \\
\text { independent cantons into a united } \\
\text { federation and converting the central } \\
\text { council into an assembly elected by direct, } \\
\text { universal and equal suffrage." (Carstains, } \\
\text { 1980, p. 135). The } 1832 \text { constitution draft } \\
\text { did not gain unanimity, and it was not until } \\
\text { after the civil war in the mid-1840s that a } \\
\text { revised constitution was adopted in May } \\
1848 \text { and the Swish Confederation was } \\
\text { established. }\end{array}$ \\
\hline 1848 & $\begin{array}{l}\text { Universal and equal suffrage for male } \\
\text { citizens of } 20 \text { years and over. This } \\
\text { franchise applied to the national } \\
\text { council. The rules for election to the } \\
\text { states council was within the } \\
\text { jurisdiction of the individual cantons } \\
\text { and thus varied. }\end{array}$ & $\begin{array}{l}\text { The Swish Confederation. Direct elections, } \\
\text { secret or oral voting according to canton } \\
\text { legislation. Majority representation: } \\
\text { constituencies varied in size (each voter } \\
\text { having as many votes as seats to be filled); } \\
\text { absolute majority required on first and } \\
\text { second ballot, simple majority on third. } \\
\text { The Constitution of } 1848 \text { established a } \\
\text { federal assembly, which included a } \\
\text { popularly elected national council and a } \\
\text { council of the states in which the cantons } \\
\text { were each equally represented. A federal } \\
\text { council (the national executive) consisting } \\
\text { of } 7 \text { members was directly elected by the } \\
\text { federal assembly. The Swish constitution } \\
\text { of } 1848 \text { was the outcome of civil war (3- } \\
29 \text { November } 1847) \text {. The first attempt at a } \\
\text { constitution, which split the district of } \\
\text { Schwyz in two and moved the cantonal } \\
\text { capital away from Schwyz, was narrowly } \\
\text { defeated on } 27 \text { January } 1848 \text {. The second } \\
\text { constitution, which removed the } \\
\text { mentioned points and merged the former } \\
\text { districts of Wollerau and Pfäffikon in the } \\
\text { district of March, was then approved by } \\
\text { the electorate on } 27 \text { February } 1848 \text {. The } \\
\text { Swiss Constitution was established with } \\
\text { the promulgation of the Constitution of } 12 \\
\text { September } 1848 \text {. }\end{array}$ \\
\hline 1850 & & $\begin{array}{l}\text { The federal law of } 1850 \text { laid down the } \\
\text { detailed rules governing elections to the } \\
\text { national council. }\end{array}$ \\
\hline 1864 & & $\begin{array}{l}\text { Serious riots in Geneva in protest against } \\
\text { misrepresentation. The canton fell into a }\end{array}$ \\
\hline
\end{tabular}




\begin{tabular}{|l|l|l|}
\hline & & $\begin{array}{l}\text { state of anarchy, from which it was } \\
\text { rescued only by the intervention of the } \\
\text { other members of the Swiss } \\
\text { Confederation. }\end{array}$ \\
\hline 1872 & Unchanged & $\begin{array}{l}\text { Secret ballot according to federal } \\
\text { legislation. }\end{array}$ \\
\hline 1919 & Unchanged & Proportional representation. \\
\hline$(1971)$ & $\begin{array}{l}\text { Universal and equal suffrage for men } \\
\text { and women of 20 years and over. }\end{array}$ & Women's suffrage. \\
\hline
\end{tabular}

Table A12: Denmark (in the sample from 1820).

\begin{tabular}{|c|c|c|}
\hline Year & Franchise extensions/contractions & Other features \\
\hline 1820 & & Absolute monarchy. \\
\hline 1831 & $\begin{array}{l}\text { Franchise based on property } \\
\text { ownership. Allowed the nobility, } \\
\text { the property owners in the cities } \\
\text { and major farmers to vote. }\end{array}$ & $\begin{array}{l}\text { Advisory regional councils } \\
\text { (Staenderforsamlingerne) re-established by the } \\
\text { King. First meetings in } 1835 \text {. }\end{array}$ \\
\hline 1849 & $\begin{array}{l}\text { Equal but restricted suffrage for } \\
\text { male citizens of } 30 \text { years and over, } \\
\text { except servants and farm laborers } \\
\text { not having their own household } \\
\text { and those receiving or having } \\
\text { received public poor relief. }\end{array}$ & $\begin{array}{l}\text { Bi-cameral system. Direct elections; voting by } \\
\text { ballot or by show of hands. Majority } \\
\text { representation: simple plurality system in } \\
\text { single-member constituencies. The } \\
\text { announcement of constitutional reform was } \\
\text { made from the balcony of the King's palace on } \\
\text { March } 18,1848 \text {. }\end{array}$ \\
\hline 1866 & & $\begin{array}{l}\text { A constitutional revision in which the major } \\
\text { landowners and the wealthier middle classes } \\
\text { succeeded in introducing changes which } \\
\text { conferred electoral privileges upon themselves, } \\
\text { and ensured that there would be a Conservative } \\
\text { majority in the Landsting [the Upper } \\
\text { Chamber]. The franchise rules for the Lower } \\
\text { Chamber were unchanged. }\end{array}$ \\
\hline $\begin{array}{l}1875- \\
1901\end{array}$ & & $\begin{array}{l}\text { The Liberals gained a majority, and between } \\
1875 \text { and } 1901 \text { the Conservative government } \\
\text { ruled by means of provisional legislation } \\
\text { without the authority of the parliament. }\end{array}$ \\
\hline 1901 & Unchanged & $\begin{array}{l}\text { From 1901, a system that made the } \\
\text { government responsible to the government was } \\
\text { introduced along with the secret ballot. }\end{array}$ \\
\hline 1915 & $\begin{array}{l}\text { Universal and equal suffrage for all } \\
\text { men and women of } 29 \text { years and } \\
\text { over. The election required for the } \\
\text { change in the constitution took } \\
\text { place on May } 7 .\end{array}$ & $\begin{array}{l}\text { Direct elections with secret ballot. Proportional } \\
\text { representation. Women had obtained the right } \\
\text { to vote for local elections in } 1909 \text {. }\end{array}$ \\
\hline 1920 & Voting age reduced to 25. & \\
\hline
\end{tabular}




\section{The broader European sample}

Table A13: Hungary (in the sample from 1867).

\begin{tabular}{|c|c|c|}
\hline Year & $\begin{array}{l}\text { Franchise } \\
\text { extensions/contractions }\end{array}$ & Other features \\
\hline 1820 & A Hungarian Diet & $\begin{array}{l}\text { Part of the Habsburg Empire and under Austrian } \\
\text { control within the German Confederation. }\end{array}$ \\
\hline 1848 & & $\begin{array}{l}\text { Hungarian Revolution. After the unsuccessful } \\
\text { revolution, Emperor Franz Joseph again assumed } \\
\text { absolute control and divided the non-German part of } \\
\text { the Austrian Empire into four distinct territories: } \\
\text { Hungary, Transylvania, Croatia-Slavonia, and } \\
\text { Vojvodina. }\end{array}$ \\
\hline 1867 & See under Austria. & $\begin{array}{l}\text { Autonomy within the Austrian-Hungarian Empire. } \\
\text { Fiscal and foreign policy jointly determined. }\end{array}$ \\
\hline $\begin{array}{l}1918- \\
20\end{array}$ & & Involved in wars to establish borders. \\
\hline 1920 & $\begin{array}{l}\text { New franchise rules more } \\
\text { restricted than under the } \\
1867 \text { constitution. }\end{array}$ & New constitution. \\
\hline $\begin{array}{l}1921- \\
31\end{array}$ & & Governed by a conservative leader. \\
\hline 1929 & & Social unrest. \\
\hline $\begin{array}{l}1932- \\
36\end{array}$ & & $\begin{array}{l}\text { Fascist parties gained power and made close } \\
\text { alliances with Germany. }\end{array}$ \\
\hline 1936 & & $\begin{array}{l}\text { The Prime Minister Gyula Gombos promises a } \\
\text { "model Nazi state" within two years, but it was not } \\
\text { achieved before } 1938 \text {. We keep Hungary in the } \\
\text { sample till } 1938 \text { but since one could argue that it } \\
\text { regressed to autocracy in 1936, we have checked that } \\
\text { none of the results depends on this choice. }\end{array}$ \\
\hline
\end{tabular}

Table A14: Russia (in sample from 1820, regressed into civil war 1917-18 ${ }^{3}$ ).

\begin{tabular}{|l|l|l|}
\hline Year & Franchise extensions/contractions & Other features \\
\hline 1814 & & $\begin{array}{l}\text { The control of the Kingdom of Poland } \\
\text { confirmed at the Congress of Wien. }\end{array}$ \\
\hline 1820 & $\begin{array}{l}\text { The Governing Senate was a legislative, } \\
\text { judicial, and executive body of Russian } \\
\text { Monarchs and lasted until the end of the } \\
\text { Russian Empire (in 1917). }\end{array}$ & Russian Empire. \\
\hline 1825 & & Rebellion. \\
\hline 1830 & & $\begin{array}{l}\text { Zar Nikolai frightened by the French } \\
\text { revolution. This leads to enhanced } \\
\text { control and repression. }\end{array}$ \\
\hline 1848 & & $\begin{array}{l}\text { Zar Nikolai frightened by the French } \\
\text { and German revolutions. This leads to }\end{array}$ \\
\hline
\end{tabular}

\footnotetext{
${ }^{3}$ The civil war is dated as starting in November 1917, and we let Russia exit the sample in1918.
} 


\begin{tabular}{|c|c|c|}
\hline & & enhanced control and repression. \\
\hline $\begin{array}{l}1853- \\
56\end{array}$ & & $\begin{array}{l}\text { Kremlin War with Turkey, the UK and } \\
\text { France. }\end{array}$ \\
\hline 1861 & & $\begin{array}{l}\text { Freedom for the peasants and other } \\
\text { reforms, including the introduction of } \\
\text { locally elected bodies to run social } \\
\text { security etc.; operational in } 1864 \\
\text { (country) and } 1870 \text { (town). Legal } \\
\text { system reformed. }\end{array}$ \\
\hline 1864 & & Conquest of central Asia starts. \\
\hline 1874 & & Conscription army. \\
\hline 1881 & & $\begin{array}{l}\text { New Zar rolls back some of the liberal } \\
\text { reforms. }\end{array}$ \\
\hline $\begin{array}{l}1904- \\
05\end{array}$ & & Russian-Japanese war. \\
\hline 1905 & & $\begin{array}{l}\text { First Russian Revolution. Peaceful } \\
\text { demonstration ends with bloodbath, but } \\
\text { demonstrations continue. }\end{array}$ \\
\hline 1906 & $\begin{array}{l}\text { All men of voting age, but indirect } \\
\text { elections and multiple votes. On } 18 \\
\text { February } 1905 \text { the Tzar offered to hold } \\
\text { elections to a consultative assembly to } \\
\text { calm the situation. }\end{array}$ & $\begin{array}{l}\text { Restricted constitutional rule. Bi- } \\
\text { cameral system with broad suffrage for } \\
\text { the lower chamber. Veto retained with } \\
\text { the Tzar. }\end{array}$ \\
\hline 1907 & $\begin{array}{l}\text { Restrictions on suffrage to insure a } \\
\text { conservative Duma. Elections held } \\
\text { between } 1907 \text { and } 1917 .\end{array}$ & \\
\hline 1917 & & $\begin{array}{l}\text { October revolution and subsequent } \\
\text { civil war. }\end{array}$ \\
\hline
\end{tabular}

Table A15: Poland (in sample from 1918).

\begin{tabular}{|l|l|l|}
\hline Year & $\begin{array}{l}\text { Franchise } \\
\text { extensions/contractions }\end{array}$ & Other features \\
\hline 1815 & & $\begin{array}{l}\text { The Kingdom of Poland is established at the Congress of } \\
\text { Vienna but the King is the Russian Emperor Alexander } \\
1, \text { so Poland is not an independent state. }\end{array}$ \\
\hline 1830 & $\begin{array}{l}\text { November uprising inspired by events in France and } \\
\text { Belgium. Brutally suppressed by the Russians in 1831. }\end{array}$ \\
\hline 1846 & $\begin{array}{l}\text { Peasant revolt in part of Poland that is under Austrian } \\
\text { control, the result is that Krakow becomes part of } \\
\text { Austria. Repression used. }\end{array}$ \\
\hline 1848 & $\begin{array}{l}\text { Rebellion against Prussia and Austria under inspiration } \\
\text { from revolutionary events elsewhere in Europe. } \\
\text { Repression very bloody. }\end{array}$ \\
\hline 1863 & $\begin{array}{l}\text { Rebellion in the Kingdom of Poland, demanding } \\
\text { freedom for peasants. Repression by Russia was the } \\
\text { result in 1864. }\end{array}$ \\
\hline 1867 & $\begin{array}{l}\text { Galicja (the south-eastern part of Poland) obtains } \\
\text { national independence, Polish culture can flourish in }\end{array}$ \\
\hline
\end{tabular}




\begin{tabular}{|c|c|c|}
\hline & & $\begin{array}{l}\text { Krakow. Other parts under German control are } \\
\text { suppressed. }\end{array}$ \\
\hline 1890s & & $\begin{array}{l}\text { Two political parties develop. Right-wing, anti-Semitic, } \\
\text { and anti-German party; Left-wing socialist party. }\end{array}$ \\
\hline 1918 & & $\begin{array}{l}\text { An independent Poland established at the peace } \\
\text { conference in Paris, but must fight the neighbors to } \\
\text { establish borders (lost to Czechoslovakia in 1919-20 but } \\
\text { gained Vilinus in 1920). }\end{array}$ \\
\hline 1921 & $\begin{array}{l}\text { The May Constitution: A } \\
\text { broad franchise. }\end{array}$ & $\begin{array}{l}\text { Republic of Poland: Democratic constitution; bi-cameral } \\
\text { system with weak president ("very democratic } \\
\text { constitution"). } 13 \text { governments between } 1919 \text { and } 1926 .\end{array}$ \\
\hline 1926 & $\begin{array}{l}\text { Franchise rules nominally } \\
\text { unchanged. }\end{array}$ & $\begin{array}{l}\text { Coup. August Novelization was a set of amendments to } \\
\text { the } 1921 \text { (May) Constitution by which the power of the } \\
\text { executive was enhanced. There were four main clauses } \\
\text { in the amendments: } \\
\text { (1) The President may dismiss the Sejm (parliament) } \\
\text { and the Senate. } \\
\text { (2) The President may issue acts having statutory } \\
\text { power with the approval of the Sejm. } \\
\text { (3) The Sejm may not dissolve itself. } \\
\text { (4) If the Sejm cannot agree on the state budget, the } \\
\text { budget may be passed by the government. }\end{array}$ \\
\hline 1935 & $\begin{array}{l}\text { Franchise rules nominally } \\
\text { unchanged. }\end{array}$ & $\begin{array}{l}\text { The April Constitution was the general law passed by } \\
\text { the act of the Polish Sejm on } 23 \text { April 1935. It } \\
\text { introduced a presidential system with certain elements of } \\
\text { authoritarianism. The President had wide-ranging power } \\
\text { to dismiss parliament and to veto legislation. }\end{array}$ \\
\hline
\end{tabular}

Table A16: Serbia (in sample from 1820).

\begin{tabular}{|l|l|l|}
\hline Year & Franchise extensions/contractions & Other features \\
\hline 1815 & & $\begin{array}{l}\text { National Assembly, the Skupstina, } \\
\text { established. It consisted of 22 district } \\
\text { heads, who were nominated by the } \\
\text { Prince, and representatives of the town } \\
\text { and parish counties, whose members- } \\
\text { prominent merchants, priests, etc. }- \text { were } \\
\text { nominated by the district heads. A } \\
\text { purely consultative body that convened } \\
\text { once a year. }\end{array}$ \\
\hline 1830 & No elections held & $\begin{array}{l}\text { Serbia became an internationally } \\
\text { recognized autonomous principality } \\
\text { under Turkish sovereignty and Russian } \\
\text { protection. }\end{array}$ \\
\hline 1835 & No elections held. & $\begin{array}{l}\text { Demands for representative institutions } \\
\text { and suppression of five rebellions. The } \\
\text { Prince eventually agreed to let the } \\
\text { Skupestina pass a constitution } \\
\text { (Constitution of 1835) to limit his } \\
\end{array}$ \\
& & \begin{tabular}{l} 
power, but this was abolished under \\
\hline
\end{tabular} \\
\hline
\end{tabular}




\begin{tabular}{|c|c|c|}
\hline & & $\begin{array}{l}\text { pressure from England among others, } \\
\text { and the Constitution of } 1835 \text { did not } \\
\text { become operational. }\end{array}$ \\
\hline $\begin{array}{l}1838 \\
\text { (operative } \\
\text { in 1839) }\end{array}$ & No elections held. & $\begin{array}{l}\text { Constitution of } 1838 \text {. New constitution } \\
\text { negotiated under Turkish influence. A } \\
\text { new state council of } 17 \text { life members } \\
\text { and a cabinet of four were duly } \\
\text { instituted. }\end{array}$ \\
\hline 1839-58 & & Period of oligarchy. \\
\hline $1858-60$ & & $\begin{array}{l}\text { The power of the Skupstina undermine } \\
\text { by Prince. }\end{array}$ \\
\hline $1860-68$ & & Enlightened absolutism \\
\hline 1868 & $\begin{array}{l}\text { Elections with relatively wide } \\
\text { suffrage. }\end{array}$ & $\begin{array}{l}\text { Constitution of } 1868 \text {. The constitution } \\
\text { drew to some extent upon the early } \\
\text { nineteenth-century German } \\
\text { constitutional monarchies. The main } \\
\text { features were: recognition of the } \\
\text { hereditary rights of the Obranovic } \\
\text { dynasty, the legislative power to be } \\
\text { shared by the Prince and the Skupstina, } \\
\text { the council remained a consultative } \\
\text { body, the government only responsible } \\
\text { to the Prince, principle of freedom of } \\
\text { press, and judges to be independent. }\end{array}$ \\
\hline 1870 & General elections in 1874 and 1875. & Election law adopted. \\
\hline 1875 & & $\begin{array}{l}\text { Rebellion against the Turks in } \\
\text { Hercegovina. }\end{array}$ \\
\hline 1876 & & $\begin{array}{l}\text { War with Turkey. Peace in } 1877 \text { on the } \\
\text { basis of the status quo. }\end{array}$ \\
\hline 1877 & & $\begin{array}{l}\text { Russo-Turkish war; Serbia gets } \\
\text { involved in 1878. Unrestricted } \\
\text { independence declared. Territorial } \\
\text { gains. }\end{array}$ \\
\hline 1881 & $\begin{array}{l}\text { Election won by Progressists and } \\
\text { Radicals (the Liberal lost). }\end{array}$ & $\begin{array}{l}\text { First time organized political parties } \\
\text { compete for power. }\end{array}$ \\
\hline 1881 & & $\begin{array}{l}\text { Secret Serbo-Austrian convention } \\
\text { which prevented Serbia from entering } \\
\text { political treaties with other countries } \\
\text { without the consent of Austria. }\end{array}$ \\
\hline 1882 & & Kingdom of Serbia declared. \\
\hline 1883 & $\begin{array}{l}\text { Election with Radical victory, but a } \\
\text { Progressits government appointed by } \\
\text { the King. }\end{array}$ & \\
\hline 1885 & & $\begin{array}{l}\text { Serbo-Bulgarian war. Status quo } \\
\text { preserved. }\end{array}$ \\
\hline 1886 & $\begin{array}{l}\text { Election, one-seat majority to the } \\
\text { Progressits. }\end{array}$ & \\
\hline 1888 & $\begin{array}{l}\text { Election resulting in Progressits } \\
\text { majority. }\end{array}$ & \\
\hline
\end{tabular}




\begin{tabular}{|c|c|c|}
\hline 1888 & $\begin{array}{l}\text { In the elections to the Skupstina, apart } \\
\text { from soldiers of the active army, all } \\
\text { male citizens of full age may vote if } \\
\text { they pay } 15 \text { dinars in direct taxes. The } \\
\text { tax payment requirement is higher for } \\
\text { elections ( } 60 \text { dinars). }\end{array}$ & $\begin{array}{l}\text { Constitution of } 1888 \text {. The constitution, } \\
\text { proposed by the Radical Party in } \\
\text { response to the egalitarian aspirations } \\
\text { of the nation's agrarian majority, } \\
\text { adopted a French constitutional model - } \\
\text { with a unicameral system and frequent } \\
\text { coalition governments. Shaped on the } \\
\text { model of the Belgian Constitution of } \\
\text { 1831, which in its turn was a modified } \\
\text { version of the French Charter of 1830, } \\
\text { it restored a French influence, } \\
\text { expressed for the first time in the } 1835 \\
\text { Constitution. It guaranteed civil and } \\
\text { political rights; including the freedom } \\
\text { of speech, abolished summery courts; } \\
\text { gave the Skupstina the right to table } \\
\text { bills, to pass the budget and introduced } \\
\text { direct elections and the secret ballot. }\end{array}$ \\
\hline 1893 & $\begin{array}{l}\text { Election, rigging gives Liberal } \\
\text { majority. }\end{array}$ & $\begin{array}{l}\text { Coup d'etat when a minor declares } \\
\text { himself of age. No change in the } \\
\text { constitution as such. }\end{array}$ \\
\hline 1894 & $\begin{array}{l}\text { This represents a de jure franchise } \\
\text { contraction. }\end{array}$ & $\begin{array}{l}\text { Constitution of } 1868 \text { replaces that of } \\
1888 .\end{array}$ \\
\hline 1895 & Election returns Progressits majority. & \\
\hline 1901 & & $\begin{array}{l}\text { Constitution of } 1901 \text { introduces a bi- } \\
\text { cameral system in an attempt of } \\
\text { upholding the influential role of the } \\
\text { ruler, while limiting that of the Radical } \\
\text { Party, which had enjoyed an ample } \\
\text { electoral support since the } 1888 \\
\text { Constitution. }\end{array}$ \\
\hline 1903 & $\begin{array}{l}\text { Elections in 1905, 1906, 1908, } 1912 . \\
\text { Restoration represents a de jure (and } \\
\text { de facto) franchise extension relative } \\
\text { to } 1868 \text { and } 1901 \text { constitution. }\end{array}$ & $\begin{array}{l}\text { Restore the Constitution of } 1888 . \\
\text { Serbia becomes a parliamentary } \\
\text { democracy, with a pre-dominant two } \\
\text { party system. }\end{array}$ \\
\hline $1912-13$ & & Balkan Wars. \\
\hline 1918 & & $\begin{array}{l}\text { Serbia becomes part of Yugoslavia (at } \\
\text { first the Kingdom of Serbs, Croats and } \\
\text { Slovens). }\end{array}$ \\
\hline 1920 & $\begin{array}{l}\text { Elections and political competition, } \\
\text { but with a ban on the Communist } \\
\text { party. Franchise relatively broad. }\end{array}$ & $\begin{array}{l}\text { Election to a constitutional convention } \\
\text { adopted centralist constitution. }\end{array}$ \\
\hline 1931 & $\begin{array}{l}1931 \text { constitution was accompanied } \\
\text { by an electoral law which ensured a } \\
\text { large government majority. Anti- } \\
\text { democratic. }\end{array}$ & $\begin{array}{l}\text { King Alexander's dictatorship (1929- } \\
\text { 34). Repression of, in particular, } \\
\text { communists. }\end{array}$ \\
\hline 1935 & $\begin{array}{l}\text { Election held in conditions of greater } \\
\text { freedom, but still with a system that } \\
\text { allowed the government to hold on to } \\
\text { the majority. }\end{array}$ & \\
\hline
\end{tabular}


Table A17: Rumania (in sample from 1856, regress to autocracy 1938)

\begin{tabular}{|l|l|l|}
\hline Year & Franchise extensions/contractions & Other features \\
\hline 1856 & $\begin{array}{l}\text { Some limited elections via } \\
\text { "Landsdag". }\end{array}$ & $\begin{array}{l}\text { Independence in part by the treaty of Paris } \\
\text { (1856) and in full by the treaty of Berlin (1878). }\end{array}$ \\
\hline $\mathbf{1 8 6 6}$ & $\begin{array}{l}\text { The franchise was governed by } \\
\text { property, income and literacy } \\
\text { requirements. }\end{array}$ & $\begin{array}{l}\text { The constitution established a liberal monarchy } \\
\text { with a responsible ministry and a parliament of } \\
\text { two elective chambers, but with most of the } \\
\text { power with the Prince. }\end{array}$ \\
\hline 1907 & & Peasant rising suppressed violently. \\
\hline $\mathbf{1 9 2 3}$ & Universal male suffrage. & Most of the power with the King. \\
\hline 1938 & & Military dictatorship. \\
\hline
\end{tabular}

Table A18: Greece (in sample from 1822)

\begin{tabular}{|l|l|l|}
\hline Year & $\begin{array}{l}\text { Franchise } \\
\text { extensions/contractions }\end{array}$ & Other features \\
\hline 1821 & $\begin{array}{l}\text { War of independence, with independence declared in } \\
1822 .\end{array}$ \\
\hline $\mathbf{1 8 2 2}$ & $\begin{array}{l}\text { Universal but unequal male } \\
\text { suffrage. }\end{array}$ & Indirect elections. \\
& $\begin{array}{l}\text { Universal and equal male } \\
\text { suffrage with voting age of }\end{array}$ & $\begin{array}{l}\text { Direct majority elections in multi-member } \\
\text { constituencies. Multiple voting. Secret ballot whereby } \\
\text { voters could write the name of the candidate in private. } \\
\text { Illiterates helped by pooling officers. }\end{array}$ \\
\hline 1864 & Voting age reduced to 21. & $\begin{array}{l}\text { Lead ball system replaced ballots. Candidates elected } \\
\text { by plurality system in one ballot in which a yes or no } \\
\text { vote was expressed by putting the ball into the } \\
\text { appropriate box. From 1923 paper ballots in some } \\
\text { provinces. From1926 paper ballots in all provinces }\end{array}$ \\
\hline 1926 & Unchanged & Proportional representation introduced. \\
\hline 1928 & Unchanged & Majority system introduced. \\
\hline 1929 & Unchanged & Compulsory voting introduced. \\
\hline
\end{tabular}


Table A19: Iceland (in sample from 1874).

\begin{tabular}{|c|c|c|}
\hline Year & Franchise extensions/contractions & Other features \\
\hline $\begin{array}{l}1814- \\
1873\end{array}$ & & $\begin{array}{l}\text { In 1814, following the } \\
\text { Napoleonic Wars, Iceland } \\
\text { remained a Danish } \\
\text { dependency. }\end{array}$ \\
\hline 1845 & & $\begin{array}{l}\text { The modern parliament, } \\
\text { Alpingi (English: Althing), } \\
\text { was founded in } 1845 \text { as an } \\
\text { advisory body to the Danish } \\
\text { monarch. }\end{array}$ \\
\hline 1874 & $\begin{array}{l}\text { Right to vote restricted to men aged } 25 \text { and over in } \\
\text { charge of own finances and property and not } \\
\text { receiving poor relief. Census and capacity } \\
\text { conditions: 1) farmers paying tax over a given } \\
\text { minimum; 2) town burghers and fishermen paying } \\
\text { communal tax over eight crowns; } 3 \text { ) owners of real } \\
\text { estate paying a communal tax of } 12 \text { crowns on } \\
\text { house property; 4) civil servants; and 5) graduates } \\
\text { of university and divinity school. }\end{array}$ & $\begin{array}{l}\text { Denmark granted Iceland a } \\
\text { constitution and limited home } \\
\text { rule. } \\
\text { Direct elections of } 30 \mathrm{MPs} \text {; } \\
\text { majority system with multiple } \\
\text { votes. } 6 \text { MPs appointed by the } \\
\text { Danish King. }\end{array}$ \\
\hline 1903 & & $\begin{array}{l}\text { Simper plurality system } \\
\text { introduced. }\end{array}$ \\
\hline 1904 & & Home rule expanded. \\
\hline 1908 & $\begin{array}{l}\text { As before with two modifications: } 1 \text { ) tax for non- } \\
\text { farm laborers lowered to } 4 \text { crowns; } 2 \text { ) graduates of } \\
\text { medical schools granted voting rights. }\end{array}$ & $\begin{array}{l}\text { Directly elected MP increased } \\
\text { from } 30 \text { to } 34.6 \text { appointed by } \\
\text { the Danish King. }\end{array}$ \\
\hline 1916 & $\begin{array}{l}\text { Universal suffrage for men and women with age } \\
\text { restrictions for women and servants; recipients of } \\
\text { poor relief not included. }\end{array}$ & $\begin{array}{l}\text { Direct elections and all } 40 \\
\text { members now elected. } \\
\text { Women's suffrage. }\end{array}$ \\
\hline 1918 & & $\begin{array}{l}\text { The Danish-Icelandic Act of } \\
\text { Union, an agreement with } \\
\text { Denmark signed on } 1 \\
\text { December } 1918 \text { and valid for } \\
25 \text { years, recognized Iceland } \\
\text { as a fully sovereign state in a } \\
\text { personal union with the King } \\
\text { of Denmark. }\end{array}$ \\
\hline 1920 & Age restrictions for women and servants abolished. & $\begin{array}{l}\text { Mixed PR-plurality system } \\
\text { introduced. }\end{array}$ \\
\hline 1934 & $\begin{array}{l}\text { Voting age lowered for men and women. } \\
\text { Recipients of poor relief enfranchised. }\end{array}$ & \\
\hline (1944) & & $\begin{array}{l}\text { The Republic of Iceland was } \\
\text { established. }\end{array}$ \\
\hline
\end{tabular}


Table A20: Luxembourg (in sample from 1820).

\begin{tabular}{|c|c|c|}
\hline Year & Franchise extensions/contractions & Other features \\
\hline 1815 & & $\begin{array}{l}\text { Luxembourg was disputed between } \\
\text { Prussia and the Netherlands. The Congress } \\
\text { of Vienna established Luxembourg as a } \\
\text { Grand Duchy in personal union with the } \\
\text { Netherlands. Luxembourg also became a } \\
\text { member of the German Confederation. } \\
\text { Since the country exists as an independent } \\
\text { state from } 1815 \text { to 1838, we let it enter the } \\
\text { sample in } 1820 \text {. }\end{array}$ \\
\hline 1839 & & $\begin{array}{l}\text { The Belgian Revolution of } 1830-1839 \\
\text { reduced Luxembourg's territory by more } \\
\text { than half. The First Treaty of London } \\
\text { reaffirmed Luxembourg's independence. }\end{array}$ \\
\hline 1841 & $\begin{array}{l}\text { Suffrage limited to men of } 25 \text { years and } \\
\text { over paying a yearly tax of } 10 \text { guilders. } \\
\text { The tax was } 20 \text { for the electors. }\end{array}$ & Indirect elections. \\
\hline 1848 & $\begin{array}{l}\text { Census (tax) reduced from } 10 \text { guilders to } \\
10 \text { francs. }\end{array}$ & $\begin{array}{l}\text { Direct elections. The Constitution of } \\
\text { Luxembourg was acutely amended on } 20 \\
\text { March, } 1848 .\end{array}$ \\
\hline 1857 & $\begin{array}{l}\text { Census of } 10-125 \text { francs for indirect } \\
\text { elections in the cantons and over } 125 \text { for } \\
\text { direct elections in the districts. But the } \\
\text { same year, in which direct elections } \\
\text { were abolished, the census was generally } \\
\text { established at } 10 \text { francs. }\end{array}$ & Mixed indirect and direct elections. \\
\hline 1860 & Census requirement raised to 30 francs. & Direct elections replace indirect elections. \\
\hline 1867 & & $\begin{array}{l}\text { The Second Treaty of London affirms } \\
\text { Luxembourg's independence and } \\
\text { neutrality. }\end{array}$ \\
\hline 1868 & $\begin{array}{l}\text { Census requirement kept at a payment of } \\
30 \text { francs. }\end{array}$ & Direct and equal elections. \\
\hline 1879 & & Secret ballot. \\
\hline 1893 & $\begin{array}{l}\text { Census requirement reduced to } 15 \\
\text { francs. }\end{array}$ & \\
\hline 1902 & $\begin{array}{l}\text { Census requirement reduced to } 10 \\
\text { francs. }\end{array}$ & \\
\hline 1919 & $\begin{array}{l}\text { Universal and equal suffrage for both } \\
\text { men and women. Voting age } 21 \text {. }\end{array}$ & $\begin{array}{l}\text { Proportional representation introduced. } \\
\text { Direct elections. }\end{array}$ \\
\hline
\end{tabular}


Table A21: Portugal (in from 1820, regress to autocracy in 1926).

\begin{tabular}{|c|c|c|}
\hline Year & Franchise extensions/contractions & Other features \\
\hline 1820 & $\begin{array}{l}\text { All free male citizens entitled to vote for the } \\
\text { constitutional assembly. }\end{array}$ & Indirect elections. \\
\hline 1822 & $\begin{array}{l}\text { Franchise for all men aged } 25 \text { and over, except for } \\
\text { males under guardianship, servants, and friars. }\end{array}$ & $\begin{array}{l}\text { Direct elections. Secret } \\
\text { ballot. }\end{array}$ \\
\hline 1826 & $\begin{array}{l}\text { Franchise for all men aged } 25 \text { and over with an income } \\
\text { of } 100 \text { milreis a year, except for males under } \\
\text { guardianship, servants and friars. Voting age of 21, and } \\
\text { over for members of clergy, married men, military } \\
\text { officers and persons with higher education. }\end{array}$ & $\begin{array}{l}\text { Indirect elections. The } \\
\text { Carta constitution. Two- } \\
\text { chamber parliament. This } \\
\text { charter formed the basis } \\
\text { for election till } 1910 \text { (the }\end{array}$ \\
\hline $\begin{array}{l}1838- \\
42\end{array}$ & Census requirement reduced to 80 milreis. & Direct elections. \\
\hline 1852 & $\begin{array}{l}\text { Census requirement abolished for teachers, graduates of } \\
\text { universities, and the clergy. }\end{array}$ & $\begin{array}{l}\text { Direct elections in multi- } \\
\text { member constituencies. }\end{array}$ \\
\hline 1878 & $\begin{array}{l}\text { Franchise extended to all men aged } 21 \text { and over who } \\
\text { were heads-of-households or who could read and write. }\end{array}$ & \\
\hline 1895 & $\begin{array}{l}\text { Income requirement for illiterates halved. Head-of- } \\
\text { household qualification discontinued. This on the } \\
\text { allowed more illiterates to vote, but the reduced caused } \\
\text { by the discontinuation of the head-of-household } \\
\text { franchise reduced the number of voters by more. So the } \\
\text { net result was a contraction. Mackie and Rose (1991, } \\
\text { Chapter } 20 \text { ) suggest that the contraction was from } 70 \% \\
\text { to } 47 \% \text {. }\end{array}$ & \\
\hline 1911 & $\begin{array}{l}\text { Enfranchisement of all men of } 21 \text { years and over who } \\
\text { could read and write plus heads-of-households (similar } \\
\text { to the } 1878 \text { electoral law). Tax qualifications were } \\
\text { abolished. }\end{array}$ & $\begin{array}{l}\text { Mixed electoral system. } \\
\text { The Monarchy was } \\
\text { overthrown and a republic } \\
\text { declared. }\end{array}$ \\
\hline 1913 & $\begin{array}{l}\text { The head-of-household qualification abolished thus } \\
\text { contracting the size of the electorate. }\end{array}$ & \\
\hline 1926 & & Dictatorship. \\
\hline
\end{tabular}

Table A22: Spain (in sample from 1820, civil war from 1936)

\begin{tabular}{|l|l|l|}
\hline Year & Franchise extensions/contractions & Other features \\
\hline $\mathbf{( 1 8 1 2 )}$ & $\begin{array}{l}\text { Constitution of Cadiz (or of 1812): Universal } \\
\text { manhood suffrage with voting age at 21; all } \\
\text { financially-independent men enfranchised. }\end{array}$ & $\begin{array}{l}\text { The constitution introduced } \\
\text { the principles of universal } \\
\text { male suffrage, national } \\
\text { sovereignty, constitutional } \\
\text { monarchy and freedom of the } \\
\text { press, and supported land } \\
\text { reform and free enterprise. }\end{array}$ \\
\hline $\mathbf{( 1 8 1 4 )}$ & & $\begin{array}{l}\text { Constitution abolished by } \\
\text { Ferdinand VII. }\end{array}$ \\
\hline $\mathbf{1 8 2 0}-$ & Constitution of Cadiz reinstated. & $\begin{array}{l}\text { Ferdinand VII's misrule } \\
\text { provoked a revolt in favor of } \\
\text { the Constitution of 1812 and } \\
\text { he was held prisoner till 1823. }\end{array}$ \\
\hline
\end{tabular}




\begin{tabular}{|c|c|c|}
\hline $\begin{array}{l}1823- \\
1833\end{array}$ & $\begin{array}{l}\text { Absolutism. Ferdinand VII used his veto powers to } \\
\text { prevent the liberal governments from functioning. }\end{array}$ & $\begin{array}{l}\text { Ferdinand VII regained power } \\
\text { after French invasion. } \\
\text { Relentless restoration of } \\
\text { reactionary absolutism. }\end{array}$ \\
\hline 1827 & & $\begin{array}{l}\text { Reactionary revolt (known as } \\
\text { "War of the Agraviados"). } \\
\text { Suppressed. }\end{array}$ \\
\hline $\begin{array}{l}\text { 1834- } \\
1836\end{array}$ & $\begin{array}{l}\text { Royal statute (Estatuto Real): census introduced on } \\
\text { the basis of tax payment and voting age raised to } 30 \\
\text { years. This reduced the suffrage relative to the } \\
\text { Constitution of Cadiz but expanded it relative to the } \\
\text { de facto franchise between } 1823 \text { and } 1833 \text {. }\end{array}$ & $\begin{array}{l}\text { Indirect elections in two } \\
\text { steps. Bicameral parliament } \\
\text { with elected lower house and } \\
\text { appointed Senate. }\end{array}$ \\
\hline 1836 & $\begin{array}{l}\text { Restoration of } 1812 \text { constitution, while preparing } \\
\text { the Constitution of } 1837 .\end{array}$ & $\begin{array}{l}\text { A coup by sergeants of the } \\
\text { Spanish Royal Guard. }\end{array}$ \\
\hline 1837 & $\begin{array}{l}\text { Constitution of 1837: franchise for all men aged } 25 \\
\text { and over who either paid annual tax of } 200 \text { reales, } \\
\text { had yearly income of } 1500 \text { reales, paid } 3000 \text { reales } \\
\text { of lease holding or rent, or were inhabitants of a } \\
\text { house of a sufficient rental value. About five } \\
\text { percent of the population had the right to vote. } \\
\text { Broader franchise than under the Royal Charge, but } \\
\text { narrower than under the Constitution of } 1812 \text {. }\end{array}$ & $\begin{array}{l}\text { Direct elections with a broad } \\
\text { electorate choosing a lower } \\
\text { house (the Chamber of } \\
\text { Deputies), while the upper } \\
\text { house (the Senate) was } \\
\text { appointed by the monarch. }\end{array}$ \\
\hline $\begin{array}{l}1840- \\
43\end{array}$ & & $\begin{array}{l}\text { Constitution of } 1837 \text { partially } \\
\text { suspended by Regent } \\
\text { Baldomero Espartero, who } \\
\text { ruled by decree between } 1840 \\
\text { and } 1843 \text {. }\end{array}$ \\
\hline 1845 & $\begin{array}{l}\text { Constitution of 1845: census requirement increased } \\
\text { to } 400 \text { reales, census of } 200 \text { reales only for some } \\
\text { professional categories. Narrowed the franchise to } \\
\text { less than one percent of the population, i.e., more } \\
\text { restricted than the Constitution of } 1837 \text {. }\end{array}$ & Direct elections (two ballots). \\
\hline 1854 & & $\begin{array}{l}\text { Election law of } 1837 \text { used to } \\
\text { elect a constitutional } \\
\text { assembly. }\end{array}$ \\
\hline 1856 & & $\begin{array}{l}\text { New constitution passed by } \\
\text { the Parliament but not } \\
\text { enacted by the Queen. }\end{array}$ \\
\hline 1865 & $\begin{array}{l}\text { Census halved to } 200 \text { reales ( } 100 \text { for certain } \\
\text { professional categories). }\end{array}$ & $\begin{array}{l}\text { Single-ballot with plurality } \\
\text { rule. }\end{array}$ \\
\hline 1869 & $\begin{array}{l}\text { Constitution of 1869: universal male suffrage, } \\
\text { voting age } 25 .\end{array}$ & $\begin{array}{l}\text { Glorious Revolution } \\
\text { Constitution. }\end{array}$ \\
\hline 1876 & $\begin{array}{l}\text { Constitution of 1876: Universal suffrage repealed. } \\
\text { Voting age } 25 \text {. Franchise limited to persons paying } \\
\text { a property tax of } 25 \text { pesetas, a yearly trade tax of } 50 \\
\text { pesetas, or possessing a higher educational } \\
\text { qualification. }\end{array}$ & $\begin{array}{l}\text { Restoration Constitution. } \\
\text { While theoretically } \\
\text { democratic, elections were } \\
\text { routinely rigged by the } \\
\text { governing party, and in } \\
\text { practice power was shared by } \\
\text { two alternating parties (the } \\
\text { "turno" system). }\end{array}$ \\
\hline
\end{tabular}




\begin{tabular}{|c|c|c|}
\hline 1888 & $\begin{array}{l}\text { Universal male suffrage reintroduced. Voting age } \\
25 \text {. }\end{array}$ & \\
\hline 1890 & $\begin{array}{l}\text { Members of certain corporations formed special } \\
\text { constituencies to ensure representation. }\end{array}$ & \\
\hline 1907 & Voting age reduced to 23 . & Compulsory voting. \\
\hline 1923 & & $\begin{array}{l}\text { During Primo de Rivera's } \\
\text { dictatorship (1923-1930) } \\
\text { many of the Constitution of } \\
\text { 1876's articles were } \\
\text { suspended in a de facto } \\
\text { dictatorship. }\end{array}$ \\
\hline 1931 & $\begin{array}{l}\text { Second Republic Constitution. Universal and equal } \\
\text { male suffrage with voting age of } 23 \text {. }\end{array}$ & Secret ballot. \\
\hline $\begin{array}{l}1936- \\
1939\end{array}$ & & $\begin{array}{l}\text { Civil war. During the Civil } \\
\text { War (1936-1939) the } \\
\text { Constitution of } 1831 \text { was } \\
\text { abolished by the Nationalists } \\
\text { and widely disregarded in the } \\
\text { Republican zone. }\end{array}$ \\
\hline 1938 & Franco’s dictatorship. & \\
\hline
\end{tabular}


Table B1: Major Revolutionary Events, 1820-1938.

\begin{tabular}{|c|c|c|}
\hline Events & Region & Year \\
\hline $\begin{array}{l}\text { Revolution in Hungary (Moravia, Transylvania and Wallachia). } \\
\text { Started in May } 1848 .\end{array}$ & $\begin{array}{l}\text { Eastern } \\
\text { Europe }\end{array}$ & $1848-49$ \\
\hline $\begin{array}{l}\text { The "aster flowers" revolution in Hungary, ending with foreign } \\
\text { military intervention and counter revolution in } 1919 \text {. The initial } \\
\text { revolution was led by Károlyi with support from the army and } \\
\text { supporters of the social democratic party wearing aster flowers. } \\
\text { Started in November } 1918 \text {. }\end{array}$ & $\begin{array}{l}\text { Eastern } \\
\text { Europe }\end{array}$ & 1918-19 \\
\hline $\begin{array}{l}\text { Generalized revolution from } 1820 \text { to } 1823 \text { in Spain (Liberal } \\
\text { Revolution in Spain of January 1, 1820). It was started by Mutiny of } \\
\text { Spanish troops under Colonel Rafael Riego. This was an example of } \\
\text { the military pronunciamento: Liberal colonels organised in their own } \\
\text { secret officers' brotherhoods ordered their regiments to follow them } \\
\text { into insurrections. It was termination by a French invasion in } 1823 \text {. }\end{array}$ & Iberia & $1820-23$ \\
\hline $\begin{array}{l}\text { Revolution at Oporto, Portugal. This liberal revolution started } \\
\text { January in Porto, quickly spreading without resistance to several } \\
\text { other Portuguese cities and towns, culminating with the revolt of } \\
\text { Lisbon. The revolutionaries demanded the immediate return of the } \\
\text { royal court to continental Portugal, demanded a constitutional } \\
\text { monarchy to be set up in Portugal and restoration of Portuguese } \\
\text { exclusivity in the trade with Brazil. }\end{array}$ & Iberia & 1820 \\
\hline $\begin{array}{l}\text { Portuguese insurrection of General Pimenta de Castro. The } \\
\text { republicans supported by the Navy and violent civil groups revolted. } \\
\text { Started in May. }\end{array}$ & Iberia & 1915 \\
\hline Belgian revolution against Holland. Started August 25. & Belgium & 1830-33 \\
\hline $\begin{array}{l}\text { Easter Rebellion in Ireland. The rising was suppressed after seven } \\
\text { days of fighting, and its leaders were court-martialled and executed. }\end{array}$ & $\begin{array}{c}\text { British } \\
\text { Isles }\end{array}$ & 1916 \\
\hline July Revolution & $\begin{array}{c}\text { French } \\
\text { states }\end{array}$ & 1830 \\
\hline French Revolution, February & $\begin{array}{c}\text { French } \\
\text { states }\end{array}$ & 1848 \\
\hline State collapse, occupation, republican revolutions. & $\begin{array}{c}\text { French } \\
\text { states }\end{array}$ & 1870 \\
\hline $\begin{array}{l}\text { Multiple communes. In Paris, resentment against the government } \\
\text { arose and from April - May } 1871 \text { Paris workers and National Guards } \\
\text { revolted and established the Paris Commune, which maintained a } \\
\text { radical left-wing regime for two months until its bloody suppression } \\
\text { by Thiers' government in May } 1871 .\end{array}$ & $\begin{array}{c}\text { French } \\
\text { states }\end{array}$ & 1871 \\
\hline Russian revolution (unsuccessful), January 9 & $\begin{array}{c}\text { Russian } \\
\text { states }\end{array}$ & 1905 \\
\hline Russian revolution (successful), February & $\begin{array}{l}\text { Russian } \\
\text { states }\end{array}$ & 1917 \\
\hline $\begin{array}{l}\text { Revolutions in Naples and Sardinia. The Carbonari organized anti- } \\
\text { absolutist riots in Naples in July. This led to the } 1820 \text { revolution } \\
\text { which forced King Ferdinand I of the Two Sicilies to promise a } \\
\text { constitutional monarchy and the King of Sardina to accept liberal } \\
\text { reform. The revolutions were in the end repressed. }\end{array}$ & Italy & 1820 \\
\hline
\end{tabular}




\begin{tabular}{|l|c|c|}
\hline $\begin{array}{l}\text { Italian states. Insurrection in Palermo, Sicily, spreads to the mainland } \\
\text { in January, Risings in the Habsburg provinces in early March. }\end{array}$ & Italy & $1848-49$ \\
\hline Habsburg. Street fighting in Vienna in March. & Austria & $1848-49$ \\
\hline German states. First event March 3. & Germany & $1848-49$ \\
\hline
\end{tabular}

Table B2: Minor Revolutionary Events.

\begin{tabular}{|c|c|c|}
\hline Events & Region & Year \\
\hline Janissary rebellion in Constantinople & Balkans & 1826 \\
\hline Pro-constitutional uprising in Greece & Balkans & 1843 \\
\hline Revolt in Herzegovina, supported by Montenegro & Balkans & 1861 \\
\hline Revolt in Crete & Balkans & 1866-68 \\
\hline Insurrections in Bosnia, Herzegovina, Bulgaria & Balkans & $1875-78$ \\
\hline Pro-Bulgarian revolution in Eastern Roumelia & Balkans & 1885 \\
\hline Peasant insurrection in Romania & Balkans & 1888 \\
\hline Peasant insurrection in Moldovia & Balkans & 1907 \\
\hline $\begin{array}{l}\text { Young Turks' revolution in the Ottoman Empire, including } \\
\text { insurrection in Macedonia }\end{array}$ & Balkans & 1908-09 \\
\hline Albanian insurrection & Balkans & 1910 \\
\hline Venezelist rising in Greece & Balkans & 1935 \\
\hline Revolt in Crete & Balkans & 1938 \\
\hline Royalist rising in Spain & Iberia & $1822-23$ \\
\hline $\begin{array}{l}\text { Reactionary revolt (known as "War of the Agraviados" } \\
\text { (malcontents)) in Catalonia and other regions of Spain. }\end{array}$ & Iberia & 1827 \\
\hline $\begin{array}{l}\text { Progressist insurrection in Andalusia, Aragon, Catalonia and } \\
\text { Madrid, ending in constitution of } 1837\end{array}$ & Iberia & 1836 \\
\hline $\begin{array}{l}\text { Revolt of General Baldomero Espartero who seized power in } \\
\text { Spain }\end{array}$ & Iberia & 1840 \\
\hline $\begin{array}{l}\text { Rising in Barcelona, temporary declaration of republic, crushed } \\
\text { by Espartero }\end{array}$ & Iberia & 1842 \\
\hline Spanish revolution led by O'Donnell and Espartero & Iberia & $1854-56$ \\
\hline Failed insurrection of General Juan Primenta & Iberia & 1866 \\
\hline $\begin{array}{l}\text { Generalized of insurrection (Pronunciamento of Admiral Juan } \\
\text { Topete) }\end{array}$ & Iberia & 1868 \\
\hline First Spanish Republic, Carlists rising & Iberia & $1873-74$ \\
\hline Anarchist outrages in Spain & Iberia & 1890 \\
\hline Catalan general strike, insurrection & Iberia & 1909 \\
\hline Insurrection in Lisbon, proclamation of republic & Iberia & 1910 \\
\hline Royalist uprising in Northern Portugal & Iberia & 1919 \\
\hline $\begin{array}{l}\text { Failed insurrection against Portuguese military regime (by } \\
\text { 1930, Salazar in power). }\end{array}$ & Iberia & 1927 \\
\hline Barcelona rising of anarchists and syndicalists & Iberia & 1933 \\
\hline $\begin{array}{l}\text { Working-class insurrection in Asturias, general strike and } \\
\text { insurrection in Catalonia }\end{array}$ & Iberia & 1934 \\
\hline Polish rebellion in Greater Poland & $\begin{array}{c}\text { Russian } \\
\text { states }\end{array}$ & $1830-31$ \\
\hline Polish rebellion in Greater Poland & $\begin{array}{l}\text { Russian } \\
\text { states }\end{array}$ & $1863-64$ \\
\hline
\end{tabular}


Table B3: Other Revolutionary Events.

\begin{tabular}{|c|c|c|}
\hline Events & Region & Year \\
\hline Independence war in Moldavia, Wallachia & Balkans & $1821-24$ \\
\hline Independence war in Crete & Balkans & $1821-25$ \\
\hline Independence war in Greece & Balkans & 1821-31 \\
\hline Independence war in Albania & Balkans & 1830-35 \\
\hline Independence war in Bosnia & Balkans & 1831-36 \\
\hline Independence war in Moldavia & Balkans & 1848 \\
\hline Independence wars in Montenegro & Balkans & $1852-59$ \\
\hline Military coup in Greece, king deposed & Balkans & 1862 \\
\hline Independence war in Bosnia & Balkans & 1862 \\
\hline Independence war in Serbia & Balkans & 1862 \\
\hline $\begin{array}{l}\text { Independence wars in Bosnia, Herzegovina, Thessaly during } \\
\text { Russo-Turkish war }\end{array}$ & Balkans & 1878 \\
\hline Independence war in Crete & Balkans & 1878 \\
\hline Independence war in Crete, Greek and British intervention & Balkans & $1896-98$ \\
\hline Independence war in Macadonia & Balkans & 1902-03 \\
\hline Independence war in Crete & Balkans & 1905 \\
\hline Independence war in Romania & Balkans & 1909 \\
\hline Independence war in Albania during the Balkan war & Balkans & 1912 \\
\hline Overthrow of Stamboliski in Bulgaria & Balkans & 1923 \\
\hline Portuguese civil war & Iberia & $1823-24$ \\
\hline British landing in Portugal, supporting constitutionalists & Iberia & 1827 \\
\hline $\begin{array}{l}\text { Portuguese coup d'etat by Dom Miguel, followed by Miguelite } \\
\text { wars to } 1834\end{array}$ & Iberia & 1828 \\
\hline Carlist war in Spain & Iberia & 1833-39 \\
\hline Frequent insurrections in Portugal & Iberia & 1834-53 \\
\hline Spanish coup on behalf of Queen Cristina, defeated & Iberia & 1841 \\
\hline Coalition deposes Espartero; Narvaez president until 1851 & Iberia & 1843 \\
\hline Portuguese civil wars & Iberia & $1846-50$ \\
\hline $\begin{array}{l}\text { Military coup, continuation of Carlist wars to 1876, then } \\
\text { another coup on behalf of Alfonso, son of deposed Queen } \\
\text { Isabella }\end{array}$ & Iberia & 1874,1876 \\
\hline Sporadic revolts, strikes and conspiracies in Portugal & Iberia & $\begin{array}{c}1889- \\
1908\end{array}$ \\
\hline Lisbon general strike & Iberia & 1912 \\
\hline $\begin{array}{l}\text { Uprising and seizure of power by General Sidonio Paes } \\
\text { (assassinated 1918) in Portugal, defeated general strike }\end{array}$ & Iberia & 1917 \\
\hline $\begin{array}{l}\text { Mutiny of Barcelona garrison, outbreak of separatist movement, } \\
\text { coup of Primo de Rivera }\end{array}$ & Iberia & 1923 \\
\hline Attempted coup in Portugal & Iberia & 1925 \\
\hline Successful coup in Portugal & Iberia & 1926 \\
\hline Attempted coup in Catalonia & Iberia & 1926 \\
\hline Mutiny of garrison at Jaca in Spain, demanding republic & Iberia & 1930 \\
\hline $\begin{array}{l}\text { Spanish elections with large majority for Republicans; Alfonso } \\
\text { leaves, new constitution }\end{array}$ & Iberia & 1931 \\
\hline Military revolt led by General Jose Sanjurjo (in Spain) & Iberia & 1932 \\
\hline Spanish civil war & Iberia & 1936-39 \\
\hline Civil war in Ireland, Irish independence & British & $1919-23$ \\
\hline
\end{tabular}




\begin{tabular}{|l|c|c|}
\hline & Isles & \\
\hline Louis Napoleon's coup & France & 1851 \\
\hline $\begin{array}{l}\text { Kirghiz vs. Russia (violence that erupted over conscription of } \\
\text { Muslims for service in World War I) }\end{array}$ & $\begin{array}{c}\text { Russian } \\
\text { states }\end{array}$ & 1916 \\
\hline Russian civil war, broad international intervention & $\begin{array}{c}\text { Russian } \\
\text { states }\end{array}$ & $1917-21$ \\
\hline Civil war & Switzerland & $1845-47$ \\
\hline
\end{tabular}

Table C1: Summary Statistics for the Variables used in the Analysis.

\begin{tabular}{|l|c|c|c|c|c|}
\hline Variable & \#Observations & Mean & Std. Dev. & Min & Max \\
\hline Suffrage & 1297 & 47.46 & 38.60 & 0.00 & 110.10 \\
\hline TR $^{\mathrm{u}}$ (unweighted, major) & 1403 & 0.24 & 0.73 & 0.00 & 5.00 \\
\hline TR $^{\mathrm{g}}$ (geographical, major) & 1403 & 0.35 & 1.28 & 0.00 & 15.11 \\
\hline TR $^{\mathrm{l}}$ (linguistic, major) & 1403 & 0.03 & 0.16 & 0.00 & 1.44 \\
\hline TR $^{\mathrm{g}}$ (geographical, all) & 1403 & 0.71 & 1.40 & 0.00 & 15.11 \\
\hline Suffrage reforms abroad & 1448 & 0.02 & 0.06 & 0.00 & 0.61 \\
\hline Log GDP per capita & 1280 & 7.74 & 0.45 & 6.66 & 8.76 \\
\hline Trend GDP & 1110 & 7.82 & 0.42 & 6.85 & 8.76 \\
\hline Cycle GDP & 1110 & 0.0004 & 0.03 & -0.18 & 0.16 \\
\hline Log Population & 1413 & 8.85 & 1.21 & 6.79 & 11.10 \\
\hline Urbanization rate & 1278 & 206.09 & 152.54 & 0.00 & 732.00 \\
\hline War & 1330 & 0.04 & 0.21 & 0.00 & 1.00 \\
\hline WWI & 1403 & 0.04 & 0.20 & 0.00 & 1.00 \\
\hline War intensity & 1413 & 0.008 & 0.08 & 0.00 & 1.00 \\
\hline Social learning & 1403 & 0.02 & 0.06 & 0.00 & 0.61 \\
\hline Gold standard & 1403 & 0.40 & 0.49 & 0.00 & 1.00 \\
\hline Education attainment & 1237 & 0.46 & 0.50 & 0.00 & 1.00 \\
\hline Trade volume & 948 & 45.01 & 25.63 & 2.24 & 140.17 \\
\hline Wheat price spread & 529 & 0.46 & 0.17 & 0.22 & 1.13 \\
\hline Agricultural share & 952 & 404.23 & 157.97 & 52.00 & 821.05 \\
\hline Repression & 657 & 46.92 & 14.48 & 16.70 & 89.20 \\
\hline Fiscal transfers & 1007 & 9.46 & 10.96 & 0.00 & 50.40 \\
\hline AL ${ }^{\text {Home }}$ & 1192 & 0.44 & 0.55 & 0.00 & 3.05 \\
\hline AL ${ }^{\text {Abroad }}$ & 1192 & 0.10 & 0.21 & 0.00 & 1.73 \\
\hline Log Rainfall & 809 & 4.2 & 0.34 & 3.32 & 5.18 \\
\hline Rainfall, growth & 1315 & 0.52 & 0.02 & 0.47 & 0.56 \\
\hline Gini coefficient & & -0.0005 & 0.14 & -0.45 & 0.44 \\
\hline
\end{tabular}


Table D1: Results from the Event History Study I, Western European Sample. Dependent variable: reform.

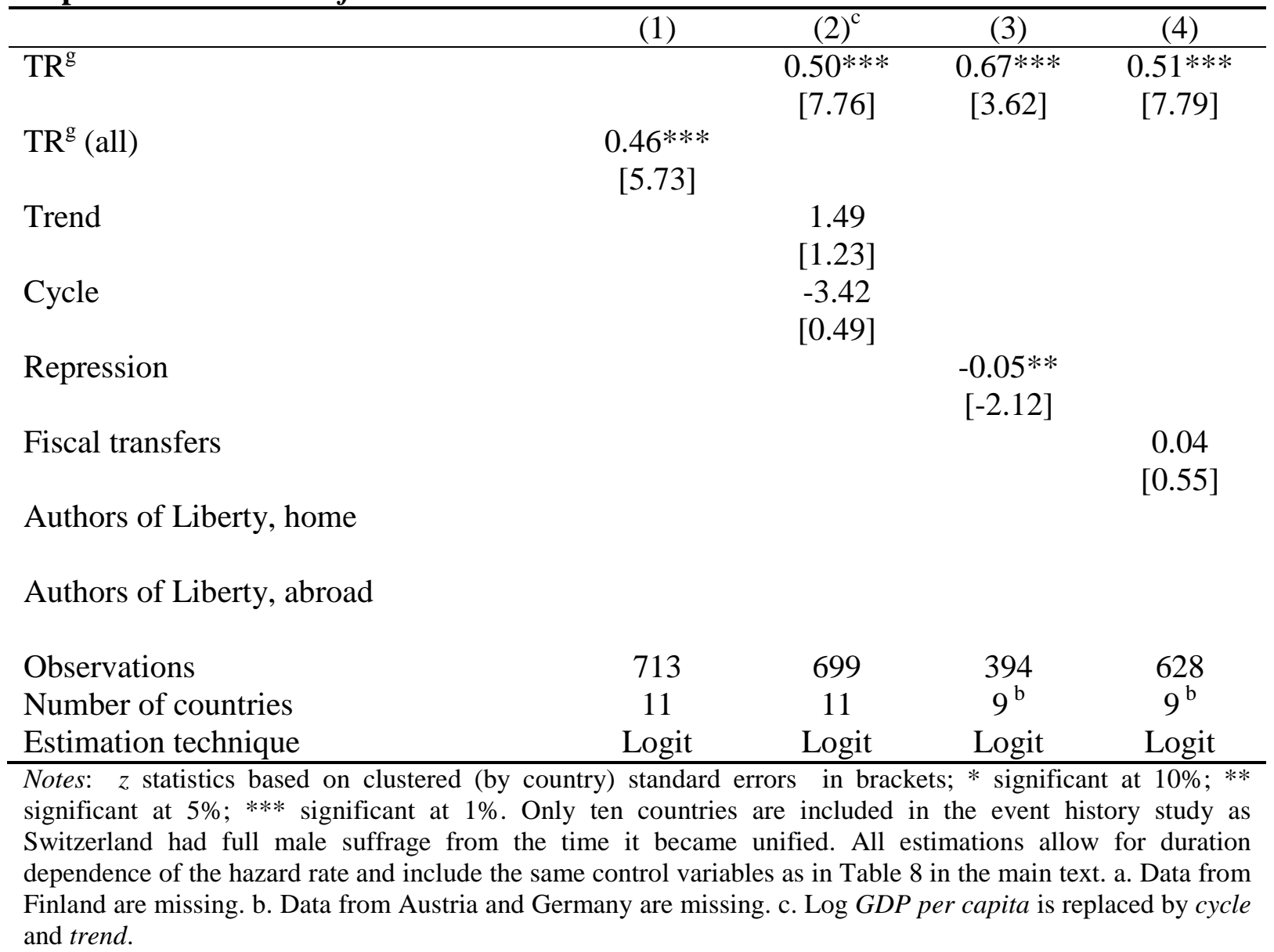

